\title{
Loopbanen na de Universiteit Maastricht: meting 2005
}

Citation for published version (APA):

de Vries, M. R. (2006). Loopbanen na de Universiteit Maastricht: meting 2005. ROA. ROA Reports No. 007 https://doi.org/10.26481/umarep.2006007

Document status and date:

Published: 01/01/2006

DOI:

10.26481/umarep.2006007

Document Version:

Publisher's PDF, also known as Version of record

\section{Please check the document version of this publication:}

- A submitted manuscript is the version of the article upon submission and before peer-review. There can be important differences between the submitted version and the official published version of record.

People interested in the research are advised to contact the author for the final version of the publication, or visit the DOI to the publisher's website.

- The final author version and the galley proof are versions of the publication after peer review.

- The final published version features the final layout of the paper including the volume, issue and page numbers.

Link to publication

\footnotetext{
General rights rights.

- You may freely distribute the URL identifying the publication in the public portal. please follow below link for the End User Agreement:

www.umlib.nl/taverne-license

Take down policy

If you believe that this document breaches copyright please contact us at:

repository@maastrichtuniversity.nl

providing details and we will investigate your claim.
}

Copyright and moral rights for the publications made accessible in the public portal are retained by the authors and/or other copyright owners and it is a condition of accessing publications that users recognise and abide by the legal requirements associated with these

- Users may download and print one copy of any publication from the public portal for the purpose of private study or research.

- You may not further distribute the material or use it for any profit-making activity or commercial gain

If the publication is distributed under the terms of Article $25 \mathrm{fa}$ of the Dutch Copyright Act, indicated by the "Taverne" license above, 


\section{Loopbanen na de Universiteit Maastricht: meting 2005}

Robert de Vries

ROA-R-2006/7 


\section{Colofon}

(C) Researchcentrum voor Onderwijs en Arbeidsmarkt (ROA). Niets uit deze uitgave mag op enige manier worden verveelvoudigd zonder voorafgaande schriftelijke toestemming van de directeur van het ROA.

\section{Researchcentrum voor Onderwijs en Arbeidsmarkt}

Faculteit der Economische Wetenschappen en Bedrijfskunde

Universiteit Maastricht

\section{Vormgeving}

ROA secretariaat, Maastricht

\section{Verkoop}

Researchcentrum voor Onderwijs en Arbeidsmarkt

email: secretary@roa.unimaas.nl

website: www.roa.unimaas.nl

ISBN-IO: 90-532I-438-O

ISBN-I3: 978-90-532I-438-I

juni 2006 


\section{Inhoud}

Voorwoord $\quad$ v

Samenvatting vii

1 Inleiding 1

1.1 Arbeidsmarktscanner Universiteit Maastricht 1

1.2 Centrale vraagstellingen en opbouw van het rapport 2

2 De huidige arbeidsmarktpositie 5

2.1 De maatschappelijke positie 6

2.2 De huidige baan 7

2.3 Competenties 15

2.4 Een evaluatie van de baan, studiekeuze en ontwikkelingsmogelijkheden 20

2.5 Conclusie 25

3 De loopbaan van Maastrichtse alumni $\quad 27$

$\begin{array}{lll}3.1 & \text { Een retrospectieve kijk op loopbanen } & 27\end{array}$

$\begin{array}{ll}3.2 & \text { Individuele loopbaanpatronen } \\ 3.3 & \text { Concluse }\end{array}$

$\begin{array}{ll}3.3 \text { Conclusie } & 37\end{array}$

4 Vereiste competenties in de baan en verworven competenties in de opleiding 39

4.1 Inleiding 39

4.2 Verschillen tussen vereist en eigen niveau van competenties $\quad 40$

$\begin{array}{lll}4.3 & \text { Tekorten an competenties naar faculteit } & 41\end{array}$

$\begin{array}{ll}4.4 \text { Conclusie } & 47\end{array}$

5 Zijn de competenties die in het werken worden vereist in de opleiding opgedaan? $\quad 49$

5.1 Achtergrond 49

5.2 Welke competenties worden vooral vereist en waar zijn deze geleerd? $\quad 51$

5.3 De bijdrage van de onderwijsmethode en werkvormen aan de verwerving van competenties 53

$\begin{array}{ll}5.4 \text { Conclusie } & 60\end{array}$

Literatuur $\quad 63$

$\begin{array}{ll}\text { Bijlage } & 65\end{array}$ 



\section{Voorwoord}

Hoe vergaat het alumni van de Universiteit Maastricht na het verlaten van de opleiding? Welke factoren zijn mogelijk van invloed op een succesvolle loopbaan? In hoeverre ervaren alumni tekorten aan competenties in de huidige baan? In dit rapport worden de resultaten gepresenteerd van de meest recente metingen die zijn gehouden onder afgestudeerden van de UM, één, vijf en tien jaar na het verlaten van de opleiding. Aan de hand hiervan wordt een beeld geschetst van de arbeidsmarktintrede en het verdere verloop van de loopbaan van Maastrichtse alumni. Daarnaast worden trendcijfers over de afgelopen vijf jaar gepresenteerd. Bovendien zijn de alumni die vijf en tien jaar geleden de opleiding aan de UM hebben verlaten al eerder benaderd. Er is een koppeling gemaakt tussen de verschillende metingen. Hiermee zijn longitudinale analyses uitgevoerd die in dit rapport worden beschreven.

Sinds 1990 verricht het Researchcentrum voor Onderwijs en Arbeidsmarkt (ROA) in opdracht van het College van Bestuur periodiek onderzoek naar de arbeidsmarktintrede van afgestudeerden van de UM. Vanaf 1998 wordt daarnaast ook periodiek onderzoek gedaan naar de loopbanen van alumni van de Universiteit Maastricht. De arbeidsmarktscanner van de Universiteit Maastricht (UM Scanner) bestaat jaarlijks uit drie metingen waarbij alumni die één, vijf en tien jaar eerder zijn afgestudeerd een schriftelijke vragenlijst ontvangen.

De meting onder afgestudeerden van de UM die één jaar eerder de opleiding hebben verlaten, is uitgevoerd in het bredere kader van de WO-monitor. Dit is een in opdracht van de VSNU en de verschillende universiteiten uitgevoerd landelijk onderzoek onder recent afgestudeerden. Over de WO-monitor wordt gerapporteerd in een landelijk rapport in opdracht van de VSNU. Dit landelijk rapport en de meest recente gegevens over afgestudeerden van het WO zijn te vinden op de website van het ROA: http:///www.womonitor.nl. De loopbaanmetingen onder alumni vijf en tien jaar na het verlaten van de opleiding, zijn uitgevoerd in samenwerking met het Studentenservicecentrum (SSC) van de Universiteit Maastricht en DESAN Research Solutions. Het ROA is verantwoordelijk geweest voor de methodologische en inhoudelijke aspecten van het project, de rapportages, en het beheer van de onderzoeksgegevens.

Bij het Studentenservicecentrum van de UM is aan het onderzoek meegewerkt door Maurice Evers, Angela Verheijen, Hans Smit, Simon Vogel en Ine Kuppen. Bij 
DESAN Research Solutions hebben Monique van Alphen en Han van Dongen aan het onderzoek meegewerkt. Deze rapportage is samengesteld door Robert de Vries. Verder is er bij het ROA aan het onderzoek meegewerkt door Ger Ramaekers, Esther Soudant en Paul van der Kolk. Het project wordt intern begeleid door Rolf van der Velden, hoofd van de afdeling Onderwijs en Beroepsloopbaan 


\section{Samenvatting}

\section{Minder gunstige perspectieven voor recent afgestudeerden}

Voor Maastrichtse alumni die recent de UM hebben verlaten is de situatie op de arbeidsmarkt minder gunstig dan voorheen. Alumni die in het academisch jaar 2003/2004 zijn afgestudeerd zijn vaker werkloos dan de jaren ervoor. Dit geldt vooral voor afgestudeerden economie, rechten en psychologie. Het bruto uurloon van recent afgestudeerden is na jaren van stijging voor het eerst iets gedaald. Het aandeel recent afgestudeerden met een vaste baan en het aandeel recent afgestudeerden met een baan van WO-niveau is vrijwel onveranderd ten opzichte van eerdere metingen.

Het aandeel werklozen onder afgestudeerden die vijf en tien jaar geleden de UM hebben verlaten is gering en vrijwel niet veranderd ten opzichte van de vorige metingen. Trendcijfers voor de periode 200I-2005 laten wel zien dat het aandeel parttimers onder afgestudeerden van de UM is toegenomen. Bovendien geldt dat Maastrichtse alumni in de latere stadia van de loopbaan steeds vaker kiezen voor een parttime baan. Dit geldt vooral voor afgestudeerde medici. Ook voor afgestudeerden die vijf en tien jaar eerder de opleiding hebben verlaten geldt dat het bruto uurloon iets is gedaald in vergelijking met voorgaande jaren. Afgestudeerde medici verdienen tien jaar na afstuderen duidelijk meer dan afgestudeerden van andere faculteiten.

Het merendeel van de alumni van de UM is tevreden over de destijds gemaakte studiekeuze. Daarbij geven economen, medici en juristen het vaakst aan dat ze achteraf gezien opnieuw voor dezelfde opleiding zouden kiezen. Relatief veel gezondheidswetenschappers die vijf en tien jaar geleden de opleiding hebben verlaten zeggen achter gezien liever een andere opleiding te hebben gevolgd. Gezondheidswetenschappers noemen vaak geneeskunde en psychologie als mogelijke opleidingen die ze liever hadden gevolgd.

\section{De gevolgen van een minder goede start van de loopbaan}

De meest recente meting laat voor alumni die tien jaar eerder zijn afgestudeerd een duidelijke trendbreuk zien in het aandeel werkenden met een baan op WO-niveau. Tot meting 2004 geldt dat ongeveer 80 procent van de alumni een baan op WOniveau heeft. In 2005 is dit gedaald naar 70 procent. Waarschijnlijk speelt hierbij 
mee dat deze laatste groep op een vrij ongunstig moment de arbeidsmarkt hebben betreden. Een andere aanwijzing hiervoor is dat relatief weinig alumni die tien jaar geleden de arbeidsmarkt betraden, aangeven dat de opleiding een goede basis bood om te starten op de arbeidsmarkt.

Het voorgaande is van belang aangezien een minder goede intrede op de arbeidsmarkt gevolgen heeft voor de verdere loopbaan. Afgestudeerden van de UM die bij de start van hun carrière een goede arbeidsmarktpositie weten te verwerven, hebben in de verdere loopbaan nog steeds een goede positie op de arbeidsmarkt. Dit blijkt in veel mindere mate te gelden voor afgestudeerden die bij het begin van hun loopbaan een minder goede positie op de arbeidsmarkt weten te verwerven. Zo heeft 87 procent van de alumni die beginnen in een baan van WO-niveau na vijf nog steeds een baan van WO-niveau. Van de alumni die starten in een baan van HBO-niveau of lager heeft slechts 45 procent na vijf jaar een baan van WO-niveau. En voor alumni die tien jaar eerder de opleiding hebben verlaten zijn deze percentages vergelijkbaar, respectievelijk 85 procent en 48 procent. Hetzelfde doet zich voor bij fulltime banen en de aansluiting van de baan bij de gevolgde opleidingsrichting. Alleen bij de baanzekerheid zien we dat het effect van een minder goede start gedurende de loopbaan wegebt.

De beloning geeft een goede indicatie van de groei die alumni in hun loopbaan doormaken. De reële lonen (loon gecorrigeerd voor inflatie) zijn voor Maastrichtse alumni in de periode tussen één en vijf jaar na afstuderen met 56 procent gestegen. In de periode tussen één en tien jaar na afstuderen is deze met maar liefst I27 procent gestegen. Vooral het loon van medici is na tien jaar flink toegenomen.

\section{Tekorten aan competenties}

Wanneer voor 25 verschillende competenties het vereist niveau in het werk wordt vergeleken met het eigen niveau kan worden achterhaald in hoeverre Maastrichtse alumni tekorten aan competenties ervaren in de huidige baan. Hieruit blijkt dat alumni het vaakst aangeven dat het vereist niveau in het werk van de competentie vermogen om aan anderen duidelijk maken wat u bedoelt hoger is dan het eigen niveau. Dit geldt zowel voor recent afgestudeerden als voor afgestudeerden van de UM die zich al langer op de arbeidsmarkt bevinden.

Opvallend is dat relatief veel medici en juristen aangeven dat ze een tekort ervaren in de competentie kennis van het eigen vakgebied. Dit tekort blijft bij medici in de latere stadia van de loopbaan bestaan, in tegenstelling tot juristen. Verder ervaren Maastrichtse alumni in de latere stadia van hun loopbaan steeds meer tekorten aan de competentie vermogen om ICT te gebruiken. Dit geldt met name voor medici en gezondheidswetenschappers. Voor de overige competenties lijkt het er op dat alumni die vijf en tien jaar eerder de opleiding hebben verlaten, meegroeien met hun baan. Voor het merendeel van alumni geldt dat het eigen niveau van de competenties in vergelijkbare mate toeneemt als het vereist niveau in de baan. 
Aan de alumni is bovendien gevraagd aan te geven voor welke competenties PGO vooral een voordeel is geweest. De competentie vermogen om problemen te analyseren en op te lossen wordt hier veruit het vaakst genoemd. Wanneer de alumni wordt gevraagd aan te geven voor welke competenties PGO vooral een nadeel is geweest, dan noemen de alumni het vaakst de competentie vermogen om conform budget, planning, richtlijnen te werken.

\section{Verwerving van competenties in de opleiding}

Tot slot is bekeken in hoeverre de opleiding bijdraagt aan het verwerven van competenties die op een hoog niveau worden vereist in het werk van Maastrichtse alumni. Hiervoor zijn voor alumni van elke faculteit van de UM eerst de vijf meest voorkomende beroepen bepaald. Voor deze beroepen zijn de vijf competenties bepaald die het vaakst op een hoog niveau worden vereist in het werk (goed of uitmuntend). Voor recent afgestudeerden van de UM is nagegaan of deze competenties vooral in de WOopleiding zijn opgedaan. Voor een deel blijkt dit zo te zijn. Bij het merendeel van deze competenties zegt 50 á 60 procent van de afgestudeerden dat de competentie vooral is geleerd in de WO-opleiding. Alléén bij de FdGW loopt dit aandeel sterk uiteen, van 7I procent bij de competentie verbanden leggen tussen verschillende zaken tot 30 procent bij de competentie nieuwe ideeën en oplossingen bedenken.

Vervolgens is onderzocht in hoeverre de verschillende onderwijsmethoden en werkvormen in de opleiding bijdragen aan het verwerven van deze competenties. Hiervoor zijn gegevens gebruikt van recent afgestudeerden economie, geneeskunde, gezondheidswetenschappen, psychologie en rechten van alle universiteiten in Nederland. Hieruit kan worden geconcludeerd dat activerend onderwijs, zoals probleemgestuurd onderwijs (PGO), in veel grotere mate bijdraagt aan de verwerving van competenties die op een hoog niveau worden vereist dan traditioneel onderwijs. Dit blijkt ten eerste uit het feit dat afgestudeerden die activerend onderwijs hebben gevolgd vaker zeggen dat deze competenties in de WO-opleiding zijn geleerd dan afgestudeerden die geen activerend onderwijs hebben gevolgd. Dit verschil tussen activerend onderwijs en traditioneel onderwijs is vooral groot bij recent afgestudeerde medici en is relatief klein bij recent afgestudeerde juristen. Ten tweede blijkt dat vooral groepsopdrachten, vaardigheidstrainingen en practica bijdragen aan de mate waarin afgestudeerden competenties die op een hoog niveau worden vereist vooral hebben geleerd in het onderwijs. Een meer traditionele onderwijsvorm als hoorcollege's draagt daarentegen in veel mindere mate bij aan de verwerving van deze competenties. 



\section{Inleiding}

\subsection{Arbeidsmarktscanner Universiteit Maastricht}

Het Researchcentrum voor Onderwijs en Arbeidsmarkt (ROA) verricht sinds 1990 in samenwerking met het Studentenservicecentrum (SSC) periodiek onderzoek onder afgestudeerden van de UM. Deze UM scanner wordt uitgevoerd in opdracht van het College van Bestuur van de Universiteit Maastricht. Het betreft een langlopend project die informatie verschaft over de gevolgde opleiding, arbeidsmarktintrede en het verdere verloop van de loopbaan van Maastrichtse alumni. Hiertoe worden alumni ongeveer één jaar, vijf jaar en tien jaar na afstuderen benaderd. De afgestudeerden ontvangen een vragenlijst $\mathrm{t}^{\mathrm{I}}$ waarin wordt gevraagd naar de afgesloten opleiding, arbeidsmarktintrede, het verdere verloop van de loopbaan, verworven en vereiste competenties en de opleiding aan de UM achteraf bezien. De drie vragenlijsten die jaarlijks worden afgenomen verschillen van elkaar, afhankelijk van het tijdstip van de meting. Voor alumni die na één jaar een vragenlijst ontvangen, staat de arbeidsmarktintrede centraal. Met deze meting wordt meer inzicht verkregen in de overgang van de Universiteit Maastricht naar de arbeidsmarkt. In de vragenlijsten die alumni vijf en tien jaar na hun afstuderen ontvangen, staat het loopbaanverloop centraal.

Over de resultaten van de metingen wordt tweejaarlijks verslag gedaan in een ROArapport: Loopbanen na de Universiteit Maastricht. Het laatste rapport is uitgekomen in 2004. Ondertussen hebben er twee nieuwe metingen plaatsgevonden onder alumni van de UM. Eind 2003 en 2004 (voor alumni één jaar na afstuderen) en in het voorjaar van 2004 en 2005 (voor alumni vijf en tien jaar na afstuderen). In deze rapportage wordt hiervan verslag gedaan. In de bijlage van dit rapport wordt ingegaan op de respons van beide metingen.

Er wordt nog op andere wijze over de resultaten van dit onderzoek gerapporteerd. Voor het College van Bestuur wordt jaarlijks een Management Summary gemaakt. De afzonderlijke faculteiten ontvangen jaarlijks elk een faculteitsrapportage. Verder wordt ingegaan op verzoeken om informatie vanuit diverse geledingen van de UM.

I. Het toenemende internationale karakter van de Universiteit Maastricht leidt ertoe dat steeds meer buitenlandse studenten de opleiding volgen aan de UM. Deze buitenlandse studenten (met uitzondering van Belgische) zijn voor het eerst benaderd met een Engelse versie van de vragenlijst. 
Daarbij kan het gaan om een bijdrage aan voorlichtingdagen, voorlichtingsbrochures, symposia en onderwijsmiddagen. Bovendien worden de gegevens gebruikt voor specifieke rapportages ${ }^{2}$, scripties, dissertaties en paperbijdragen aan wetenschappelijke congressen. Daarnaast zijn de gegevens van het onderzoek recentelijk gebruikt voor het EQUIS Self-assessment Report 2005 van de Economische Faculteit van de UM. De resultaten uit de meting één jaar na afstuderen wordt ook gebruikt in een landelijke onderzoek, de WO-monitor. Over deze WO-monitor wordt gerapporteerd in een landelijk rapport in opdracht van de VSNU. Het landelijk rapport en de meest recente gegevens over afgestudeerden van het WO zijn te vinden op de website van het ROA: http:///www.womonitor.nl.

\subsection{Centrale vraagstellingen en opbouw van het rapport}

In de UM Scanner vindt een beschrijving plaats van de huidige arbeidsmarktsituatie en de verdere loopbaan van Maastrichtse alumni. Vier vragen staan in dit rapport centraal:

1. Hoe vergaat het alumni van de Universiteit Maastricht in de verschillende fasen van hun loopbaan?

2. Welke factoren zijn mogelijk van invloed op een succesvolle loopbaan?

3. In hoeverre ervaren Maastrichtse alumni tekorten aan competenties in de huidige baan?

4. Heeft de opleiding aan de UM bijgedragen aan competenties die op een hoog niveau worden vereist in het werk?

Het rapport is als volgt opgebouwd. In hoofdstuk 2 wordt ingegaan op de huidige arbeidsmarktsituatie van de alumni van de Universiteit Maastricht. Besproken wordt de maatschappelijke positie, kenmerken van de huidige baan, competenties die zijn opgedaan en worden vereist in het werk en de mate van tevredenheid met de huidige situatie. Dit hoofdstuk is vooral gericht op de vraag hoe het de Maastrichtse alumni in de verschillende fasen van hun loopbaan thans vergaat. Hierbij worden naast de meest actuele cijfers van meting 2005 ook trendcijfers voor de periode 200I-2005 gepresenteerd.

Hoofdstuk 3 gaat in op de loopbanen van de Maastrichtse alumni. In dit hoofdstuk wordt specifiek ingegaan op de loopbaanpatronen en de ontwikkeling van de arbeidsmarktpositie. Eerst worden de loopbanen van Maastrichtse alumni gereconstrueerd. Hoeveel banen en werkgevers hebben de alumni na het verlaten van de opleiding gehad? Vervolgens wordt bekeken in welke mate de start van de loopbaan van invloed is op de verdere carrière. Heeft een minder gunstige intrede op de arbeidsmarkt gevolgen op de langere termijn?

2. Zie bijvoorbeeld; Ramaekers, G. (2004). Hoe oud-studenten van de Universiteit Maastricht hun curricula evalueren. ROA: Maastricht. 
In hoofdstuk 4 wordt ingegaan op de competenties die zijn opgedaan in de opleiding en in welke mate deze competenties worden vereist in het huidige werk van de afgestudeerden van de UM. De verschillen worden bekeken tussen het eigen niveau van competenties en het vereist niveau van competenties op de arbeidsmarkt. Dit wordt apart gedaan voor de verschillende faculteiten van de UM.

In hoofdstuk 5 wordt onderzocht in hoeverre de opleiding bijdraagt aan het verwerven van competenties die vaak op een hoog niveau worden vereist in het werk van Maastrichtse alumni. Bekeken wordt in hoeverre afgestudeerden vinden dat deze competenties vooral in de WO-opleiding zijn geleerd. Bovendien wordt onderzocht op welke manier de leeromgeving (onderwijsmethode en werkvormen) bij kan dragen aan het verwerven van deze competenties. 



\section{De huidige arbeidsmarktpositie}

Dit hoofdstuk bespreekt de arbeidsmarktpositie van alumni van de Universiteit Maastricht één, vijf en tien jaar na afstuderen. Voor alumni die één jaar geleden zijn afgestudeerd is de overgang van opleiding naar arbeidsmarkt min of meer achter de rug. De arbeidsmarktpositie van deze groep geeft daarmee een antwoord op de vraag in hoeverre de opleiding aan de Universiteit Maastricht de afgestudeerde de mogelijkheid biedt een goede start op de arbeidsmarkt te maken. Na vijf jaar krijgen loopbanen een definitief karakter, en na tien jaar bereikt de loopbaan over het algemeen zijn hoogtepunt.

De opbouw van dit hoofdstuk is als volgt. In paragraaf 2.I wordt ingegaan op de huidige maatschappelijke positie van de alumni. Hierbij is aan de respondenten gevraagd hun situatie (betaald werk, werkloos en dergelijke) te omschrijven. Paragraaf 2.2 beschrijft kenmerken van de huidige baan van alumni, waaronder het soort dienstverband, de aansluiting tussen opleiding en werk en de beloning. Centraal in paragraaf 2.3 staat het vereist niveau van competenties in de baan en het eigen niveau van competenties. Daarbij worden ook eventuele discrepanties tussen vereist en eigen niveau van competenties bekeken. De slotparagraaf van dit hoofdstuk is evaluerend van aard. Aan bod komt onder meer de vraag in hoeverre Maastrichtse alumni tevreden zijn met de huidige situatie en of ze, achteraf bezien, opnieuw zouden kiezen voor dezelfde studie aan de UM?

Waar relevant worden in dit hoofdstuk ook trendcijfers vermeld. Deze cijfers hebben betrekking op de metingen 200I-2005. Voor alumni die tien jaar eerder de opleiding hebben verlaten, zijn geen cijfers voorhanden van meting 200I. De trendcijfers voor deze laatste groep hebben dan ook betrekking op de periode 2002-2005.

De arbeidsmarktsituatie was tien jaar geleden relatief ongunstig. Hetzelfde lijkt te gelden voor afgestudeerden die op dit moment de arbeidsmarkt betreden. Met deze zogenaamde cohorteffecten moet bij het vergelijken van alumni uit verschillende lichtingen en verschillende fasen rekening worden gehouden. De situatie op de arbeidsmarkt heeft zowel op de korte als lange termijn invloed op arbeidsmarktpositie van alumni. Zoals we later zullen zien in hoofdstuk 3 kan de start op de arbeidsmarkt gevolgen hebben voor de verdere loopbaan van alumni. 


\subsection{De maatschappelijke positie}

Tabel 2.Ia tot en met 2.Ic vermeldt de maatschappelijke positie van de Maastrichtse alumni voor de verschillende afstudeercohorten. Aan de respondenten is gevraagd om hun huidige situatie te omschrijven. Het gaat hier dus om een eigen inschatting van de respondenten. Met name bij de categorie werkloos dient onderstreept te worden dat het om een subjectieve inschatting gaat. Verder is in figuur 2.I voor de periode $200 \mathrm{I}-2005$ het aandeel afgestudeerden vermeld dat zegt betaald werk te hebben, één, vijf en tien jaar na afstuderen. Uit de tabellen 2.Ia tot en met 2.Ic blijkt dat het overgrote deel van de Maastrichtse alumni in 2005 betaald werk verricht. Van de alumni die één jaar geleden de Universiteit Maastricht hebben verlaten, zegt 89 procent betaald werk te hebben. Voor de alumni die vijf en tien jaar geleden zijn afgestudeerd is dit percentage respectievelijk 96 en 95 procent. Verder blijkt uit tabel 2.Ic dat relatief veel afgestudeerden van de FdR tien jaar na afstuderen behoren tot de categorie 'anders'. Het betreft hier voornamelijk vrouwelijke alumni Rechten die aangeven te zorgen voor de kinderen.

Tabel 2.1a

Maatschappelijke positie na één jaar in procenten, cohort 2002-2003, 2005

$\begin{array}{lccccccc} & \text { FdCW } & \text { FdEWB } & \text { FdG } & \text { FdGW } & \text { FdP } & \text { FdR } & \text { Totaal } \\ \text { Betaald werk } & 88 & 90 & 95 & 87 & 88 & 91 & 89 \\ \text { Studie } & 8 & 3 & 0 & 10 & 4 & 5 & 5 \\ \text { Werkloos } & 4 & 3 & 3 & 1 & 9 & 4 & 3 \\ \text { Anders } & 0 & 4 & 3 & 3 & 0 & 0 & 2\end{array}$

Bron: ROA

Tabel 2.1b

Maatschappelijke positie na vijf jaar in procenten, cohort 1998-1999, 2005

$\begin{array}{lcrrrc} & \text { FdEWB } & \text { FdG } & \text { FdGW } & \text { FdR } & \text { Totaal } \\ \text { Betaald werk } & 98 & 94 & 93 & 98 & 96 \\ \text { Studie } & 0 & 4 & 2 & 2 & 2 \\ \text { Werkloos } & 2 & 2 & 2 & 0 & 2 \\ \text { Anders } & 0 & 0 & 3 & 0 & 1\end{array}$

Bron: ROA

Tabel 2.1c

Maatschappelijke positie na tien jaar in procenten, cohort 1993-1994, 2005

$\begin{array}{lccccc} & \text { FdEWB } & \text { FdG } & \text { FdGW } & \text { FdR } & \text { Totaal } \\ \text { Betaald werk } & 96 & 99 & 95 & 93 & 95 \\ \text { Studie } & 0 & 0 & 0 & 0 & 0 \\ \text { Werkloos } & 1 & 0 & 0 & 0 & 0 \\ \text { Anders } & 3 & 1 & 4 & 7 & 4\end{array}$

Bron: ROA

Overigens geldt voor de alumni die één jaar geleden zijn afgestudeerd dat de situatie op de arbeidsmarkt minder gunstig is dan de jaren ervoor. Dit blijkt onder meer uit figuur 2.I, waarin het aandeel alumni met betaald werk is vermeld voor de periode 
200I-2005. In 200I zegt 94 procent van de Maastrichtse alumni die één jaar eerder zijn afgestudeerd, betaald werk te hebben. Dit aandeel is in 2005 gedaald naar 89 procent. Bovendien geldt dat in 2005 in totaal 4 procent van de alumni werkloos is één jaar na afstuderen, tegen I procent in 2004. Met name economen, juristen (beide 6 procent) en psychologen ( 8 procent) zeggen in 2005 relatief vaak werkloos te zijn één jaar na afstuderen. Onder afgestudeerden die vijf en tien jaar geleden de Universiteit Maastricht hebben verlaten, is het aandeel alumni dat aangeeft werkloos te zijn minimaal en vrijwel niet veranderd ten opzichte van de vorige metingen. Daarmee lijkt het erop dat vooral recent afgestudeerde UM'ers worden getroffen door de economisch minder gunstige situatie op de arbeidsmarkt op dit moment.

Figuur 2.1

Aandeel alumni met betaald werk één, vijf en tien jaar na afstuderen, 2001-2005

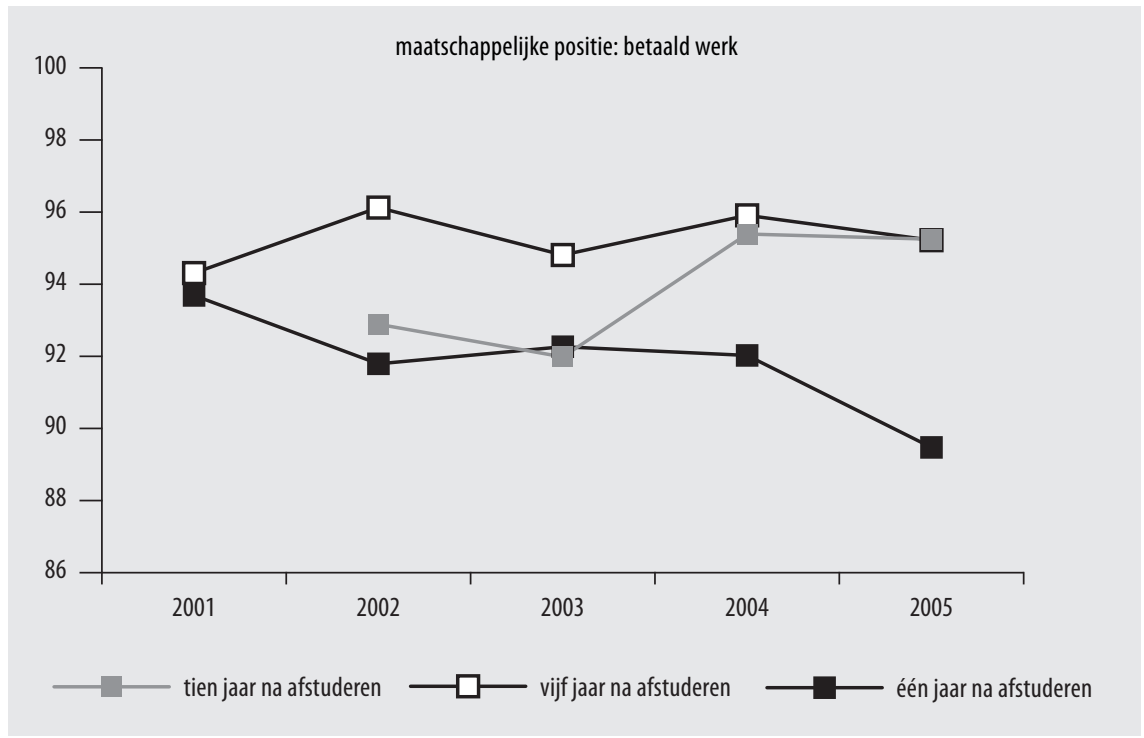

\subsection{De huidige baan}

In deze paragraaf wordt de huidige baan van alumni nader bekeken. Eerst wordt ingegaan op het soort dienstverband en aanstelling waarin alumni werkzaam zijn. In de tabellen 2.2a tot en met $2.2 \mathrm{c}$ is het soort dienstverband weergegeven. Hieruit blijkt dat het merendeel van de alumni werkzaam is in loondienst bij een werkgever. Dit geldt zowel voor alumni die één jaar geleden zijn afgestudeerd als voor alumni die vijf en tien jaar geleden zijn afgestudeerd. Een dienstverband als AIO of uitzendkracht komt vooral aan het begin van de loopbaan voor. Met name onder psychologen is het aandeel AIO's hoog. 
Het aandeel zelfstandigen onder Maastrichtse alumni neemt toe naarmate de arbeidsloopbaan vordert. Eén jaar na afstuderen is het aandeel zelfstandigen met 2 procent nog zeer klein. Van de alumni die vijf jaar geleden zijn afgestudeerd is 5 procent zelfstandige en onder tien jaar geleden afgestudeerde alumni is dit aandeel $\mathrm{r} 3$ procent. Vooral medici zijn tien jaar na afstuderen als zelfstandige werkzaam.

Tabel 2.2a

Dienstverband na één jaar in procenten, cohort 2002-2003, 2005

$\begin{array}{lccccccc} & \text { FdCW } & \text { FdEWB } & \text { FdG } & \text { FdGW } & \text { FdP } & \text { FdR } & \text { Totaal } \\ \text { Loondienst } & 78 & 85 & 82 & 82 & 46 & 87 & 80 \\ \text { Aio/Oio } & 11 & 4 & 14 & 13 & 48 & 2 & 11 \\ \text { Zelfstandige } & 11 & 4 & 0 & 1 & 0 & 2 & 2 \\ \text { Uitzendkracht } & 0 & 6 & 0 & 3 & 6 & 6 & 4 \\ \text { Anders } & 0 & 1 & 4 & 3 & 0 & 4 & 2\end{array}$

Bron: ROA

Tabel 2.2b

Dienstverband na vijf jaar in procenten, cohort 1998-1999, 2005

$\begin{array}{lcrrrc} & \text { FdEWB } & \text { FdG } & \text { FdGW } & \text { FdR } & \text { Totaal } \\ \text { Loondienst } & 93 & 72 & 92 & 92 & 88 \\ \text { Aio/0io } & 2 & 9 & 4 & 1 & 4 \\ \text { Zelfstandige } & 5 & 12 & 2 & 4 & 5 \\ \text { Uitzendkracht } & 0 & 0 & 0 & 0 & 0 \\ \text { Anders } & 1 & 7 & 2 & 2 & 3\end{array}$

Bron: ROA

Tabel 2.2C

Dienstverband na tien jaar in procenten, cohort 1993-1994, 2005

$\begin{array}{lccccc} & \text { FdEWB } & \text { FdG } & \text { FdGW } & \text { FdR } & \text { Totaal } \\ \text { Loondienst } & 93 & 53 & 90 & 92 & 85 \\ \text { Aio/Oio } & 0 & 1 & 1 & 0 & 0 \\ \text { Zelfstandige } & 5 & 44 & 8 & 8 & 13 \\ \text { Uitzendkracht } & 0 & 1 & 1 & 0 & 0 \\ \text { Anders } & 2 & 0 & 1 & 0 & 1\end{array}$

Bron: ROA

Eerder hebben we gezien dat het overgrote deel van de Maastrichtse alumni betaald werk verricht. In tabel 2.3 wordt ingegaan op de baanzekerheid. In deze tabel is voor de verschillende cohorten het aandeel afgestudeerden met een vaste aanstelling weergegeven. In figuur 2.2 zijn tevens trendcijfers vermeld over de baanzekerheid van alumni één, vijf en tien jaar na afstuderen.

Uit tabel 2.3 komt naar voren dat voor afgestudeerden van de UM de werkzekerheid toeneemt naarmate de loopbaan vordert. Na één jaar heeft ongeveer de helft van de alumni een vaste aanstelling. Onder alumni die vijf en tien jaar geleden zijn afgestudeerd is dit aandeel met respectievelijk 79 en 92 procent duidelijk hoger. Overigens valt op dat veel economen al relatief snel na het afstuderen een vaste aanstelling hebben verworven. $\mathrm{Na}$ één jaar heeft 66 procent van de economen een vaste baan. Met name de medici blijven hierbij ver achter. Hierbij dient echter rekening te worden gehouden met het gegeven dat basisartsen vaak doorstromen naar een opleidingsplaats voor 
medisch specialist. Daarnaast is ook voor veel psychologen de baanzekerheid bij de start van de loopbaan nog vrij laag. Zoals we in de vorige tabel hebben gezien, zijn veel psychologen één jaar na afstuderen werkzaam als AIO.

\section{Tabel 2.3}

Vaste aanstelling in procenten per afstudeercohort, 2005

$\begin{array}{cccccccc} & \text { FdCW } & \text { FdEWB } & \text { FdG } & \text { FdGW } & \text { FdP } & \text { FdR } & \text { Totaal } \\ 2002-2003 & 50 & 66 & 23 & 44 & 33 & 52 & 49 \\ 1998-1999 & \text { n.v.t. } & 95 & 39 & 78 & \text { n.v.t. } & 92 & 79 \\ 1993-1994 & \text { n.v.t. } & 95 & 93 & 91 & \text { n.v.t. } & 91 & 92\end{array}$

Bron: ROA

Uit figuur 2.2 blijkt dat in vergelijking met vorige metingen het aandeel Maastrichtse alumni met een vaste aanstelling vrijwel niet veranderd voor afgestudeerden één en vijf jaar na het verlaten van de opleiding aan de UM. Voor recent afgestudeerden fluctueert het aandeel alumni met een vaste baan de afgelopen tijd rond de 50 procent. Voor alumni vijf jaar na afstuderen schommelt dit rond de 80 procent. Voor afgestudeerden die tien jaar eerder de opleiding hebben verlaten, is daarentegen het aandeel met een vaste baan toegenomen; van 82 procent in 2002 naar 92 procent in 2005 .

\section{Figuur 2.2}

Aandeel afgestudeerden met een vaste aanstelling één, vijf en tien jaar na afstuderen, 2001-2005

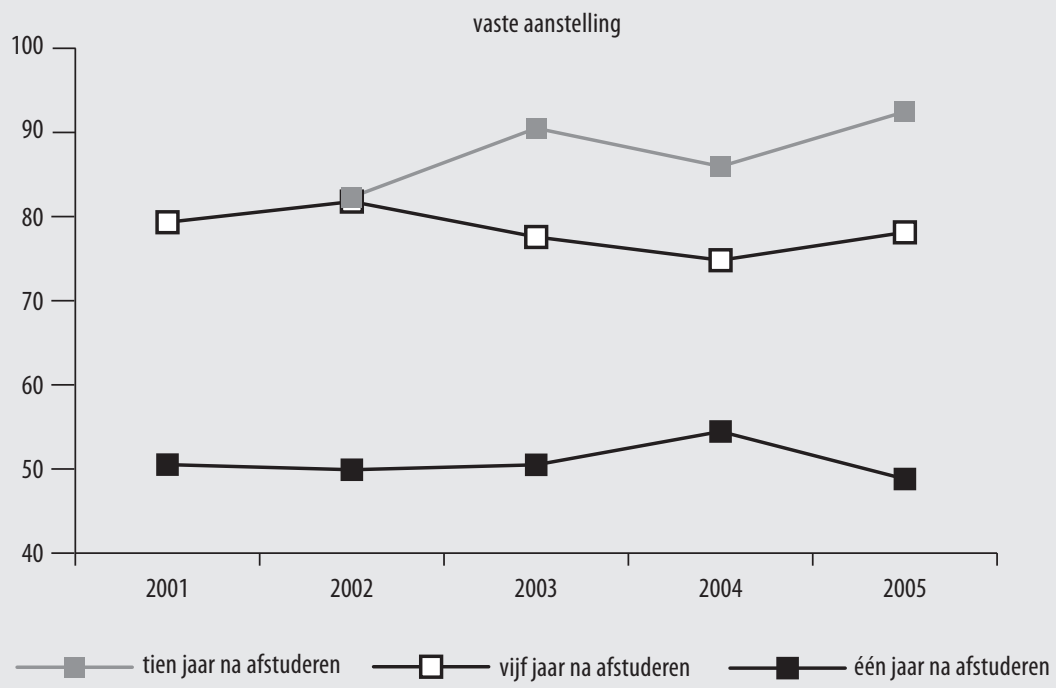

Tabel 2.4 laat het aandeel afgestudeerden zien dat werkzaam is een parttime baan. Een parttime baan betreft een baan van 32 uur of minder. Uit tabel 2.4 blijkt dat steeds meer alumni parttime gaan werken naarmate men de opleiding langer geleden heeft verlaten. $\mathrm{Na}$ één jaar werkt ongeveer 23 procent van de alumni parttime. $\mathrm{Na}$ 
vijf jaar heeft 25 procent van de alumni een parttime baan en na tien jaar 43 procent. Overigens geldt dat de faculteiten hier aanzienlijk verschillen in het aandeel alumni met een deeltijdbaan. Onder recent afgestudeerden geldt dat met name veel afgestudeerden van de faculteiten FdCW en FdGW werken in deeltijd. Voor alumni van de FdG valt in dit verband op dat met name in de latere stadia van de loopbaan het aandeel werkenden met een deeltijdbaan toeneemt. In de loopbaan van economen en juristen komt deeltijdwerk minder vaak voor. Toch loopt ook voor deze faculteiten het aandeel alumni met een deeltijdbaan op naarmate ze langer geleden de opleiding heeft verlaten.

Tabel 2.4

Parttime werk in procenten per afstudeercohort, 2005

$\begin{array}{rccccrrc} & \text { FdCW } & \text { FdEWB } & \text { FdG } & \text { FdGW } & \text { FdP } & \text { FdR } & \text { Totaal } \\ 2002-2003 & 50 & 8 & 7 & 45 & 29 & 9 & 23 \\ 1998-1999 & \text { n.v.t. } & 6 & 30 & 41 & \text { n.v.t. } & 22 & 25 \\ 1993-1994 & \text { n.v.t. } & 24 & 42 & 56 & \text { n.v.t. } & 36 & 43\end{array}$

Bron: ROA

De verschillen tussen de faculteiten kunnen deels worden verklaard door verschillen in samenstelling van de populatie. Binnen gezondheidswetenschappen zijn bijvoorbeeld vrouwen duidelijk in de meerderheid. Over het algemeen gaan vrouwen vaker dan mannen parttime werken om werk- en gezinstaken te kunnen combineren. Daarnaast zijn de gezondheidswetenschappers gemiddeld ouder dan alumni van de andere opleidingen. Gezondheidswetenschappers zijn gemiddeld drie en een half jaar ouder dan economen op het moment van afstuderen.

\section{Figuur 2.3}

Aandeel afgestudeerden met parttime werk één, vijf en tien jaar na afstuderen, 2001-2005

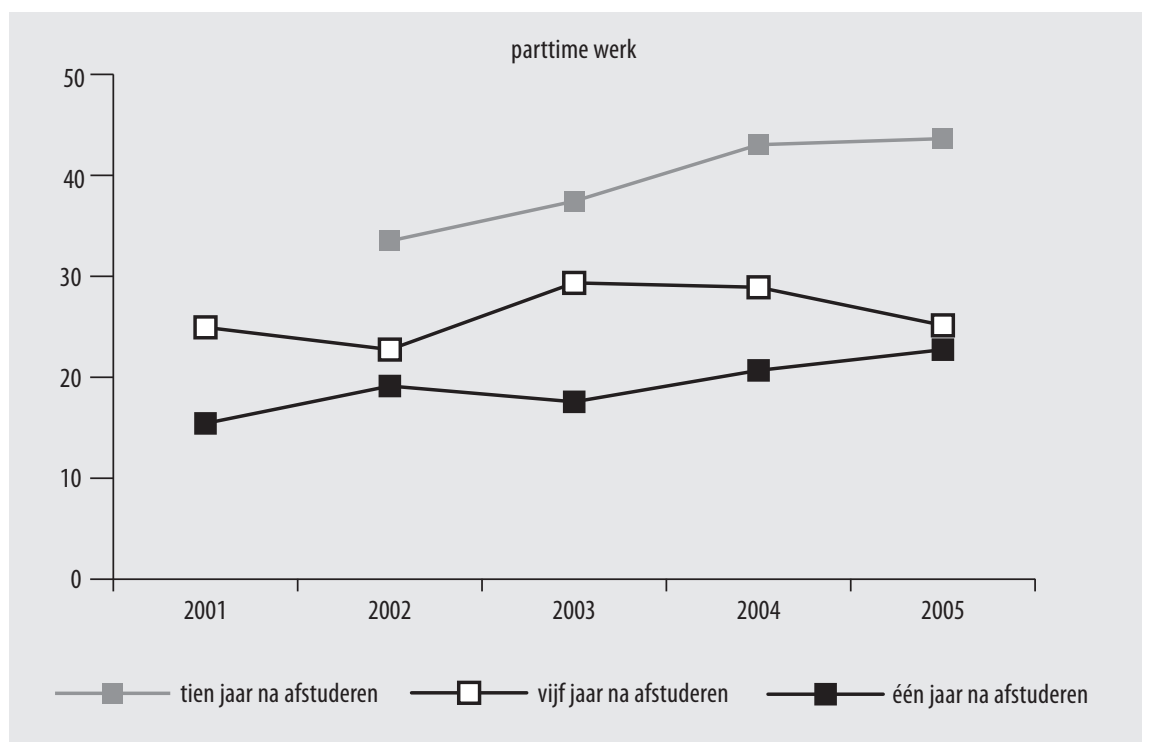


Trendcijfers laten zien dat in de afgelopen jaren het aandeel parttimers is toegenomen, vooral onder recent afgestudeerden en afgestudeerden die tien jaar eerder de opleiding aan de UM hebben verlaten (zie figuur 2.3). Voor afgestudeerden die één jaar eerder de opleiding aan de UM hebben verlaten, geldt dat het aandeel parttimers is toegenomen van 15 procent in $200 \mathrm{I}$ tot 23 procent in 2005 . Voor alumni die tien jaar eerder de opleiding hebben verlaten geldt dat in 2002 in totaal 34 procent in deeltijd werkte. Dit aandeel is in 2005 toegenomen tot 44 procent.

In de tabellen 2.5 tot en met 2.7 staat de aansluiting tussen de gevolgde opleiding en de huidige baan centraal. Op twee manieren wordt naar deze aansluiting gekeken; de aansluiting naar niveau en de aansluiting naar richting. Bij de eerste gaat het om de vraag of afgestudeerden een baan hebben gevonden van WO-niveau. Hiervoor is aan de respondenten gevraagd welk opleidingsniveau door de werkgever voor de huidige baan werd vereist. Bij de tweede gaat het om de vraag of de afgestudeerden een baan hebben gevonden die aansluit bij de gevolgde opleidingsrichting. Hiertoe is aan respondenten gevraagd of in de huidige baan de eigen/verwante studierichting werd vereist door de werkgever of geen/andere studierichting.

In tabel 2.5 is voor de verschillende cohorten het aandeel alumni weergegeven met een baan van WO-niveau. Vanuit maatschappelijk oogpunt is het belangrijk dat een afgestudeerde werkzaam is in een baan die aansluit bij het behaalde opleidingsniveau. Dit is immers de grondslag van het bestaan van verschillende onderwijssoorten. Maar ook vanuit individueel oogpunt is het belangrijk dat een afgestudeerde een baan heeft gevonden die qua niveau aansluit bij de gevolgde opleiding. In een baan van WOniveau kan de afgestudeerde de in de opleiding opgedane kennis en vaardigheden optimaal benutten, waardoor deze zich naar verwachting beter op zijn of haar plek voelen.

Tabel 2.5

Werk op WO-niveau in procenten per afstudeercohort, 2005

$\begin{array}{cccccccc} & \text { FdCW } & \text { FdEWB } & \text { FdG } & \text { FdGW } & \text { FdP } & \text { FdR } & \text { Totaal } \\ 2002-2003 & 56 & 69 & 100 & 59 & 86 & 70 & 71 \\ 1998-1999 & \text { n.v.t. } & 79 & 99 & 62 & \text { n.v.t. } & 80 & 77 \\ \text { 1993-1994 } & \text { n.v.t. } & 63 & 100 & 61 & \text { n.v.t. } & 72 & 70 \\ \text { Bron: ROA } & & & & & & \end{array}$

Uit de tabel 2.5 blijkt dat 7I procent van de alumni die één jaar geleden zijn afgestudeerd een baan heeft gevonden die aansluit bij het behaalde opleidingsniveau. Voor alumni die vijf en tien jaar geleden is dit percentage respectievelijk 77 procent en 70 procent. Daarmee is in 2005 het aandeel alumni dat tien jaar na afstuderen een baan op WO-niveau heeft relatief laag ten opzichte van de jaren ervoor (zie ook figuur 2.4). Uit hier niet gepresenteerde cijfers blijkt dat met name vrouwen tien jaar na afstuderen werkzaam zijn in een baan van HBO-niveau of lager. 
De verschillen tussen de faculteiten in het aandeel alumni met een baan op WOniveau zijn groot. Vrijwel alle medici hebben een baan gevonden die aansluit bij het behaalde opleidingsniveau. Economen en gezondheidswetenschappers komen daarentegen relatief vaak in banen terecht beneden WO-niveau. Voor veel gezondheidswetenschappers speelt hierbij mee dat ze reeds ervaring hebben opgedaan in bijvoorbeeld de verpleging en ook vaak na het afronden van de academische studie in hun vakgebied werkzaam blijven.

Figuur 2.4 laat een duidelijke trendbreuk zien in het aandeel werkenden met een baan op WO-niveau voor alumni die tien jaar eerder zijn afgestudeerd. Voor deze groep geldt dat tot meting 2004 ongeveer 80 procent van de alumni een baan op WO-niveau heeft, terwijl deze voor meting 2005 'slechts' 70 procent bedraagt. Onder recent afgestudeerden schommelt de afgelopen jaren het aandeel alumni met een baan op WO-niveau rond de 7I procent. Voor afgestudeerden die vijf jaar eerder de opleiding hebben verlaten zien we een stijging van het aandeel alumni met een baan op WO-niveau van 67 procent in 2001 naar 77 procent in 2005 .

\section{Figuur 2.4}

Aandeel afgestudeerden met een baan op WO-niveau één, vijf en tien jaar na afstuderen, 2001-2005

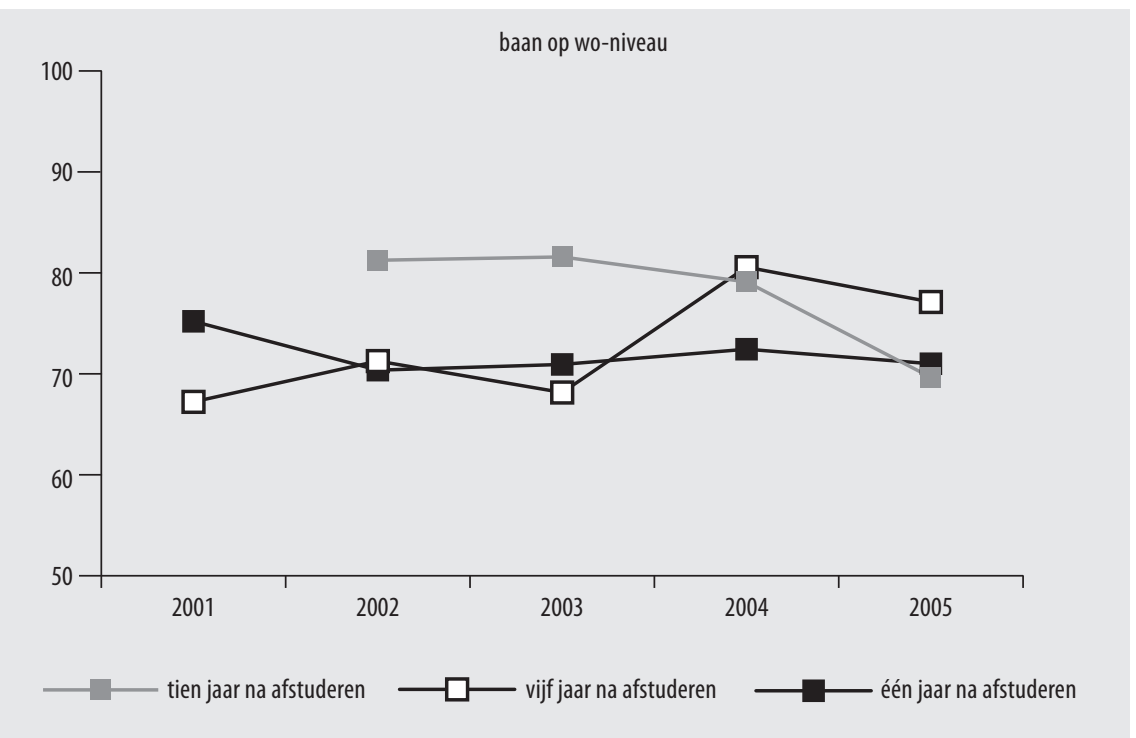

In tabel 2.6 wordt ingegaan op de aansluiting tussen opleiding en werk naar richting. Ongeveer driekwart van de Maastrichtse alumni is werkzaam in een baan die aansluit op de gevolgde opleidingrichting. Hier zien we dat recent afgestudeerden UM'ers ongeveer even vaak een baan hebben gevonden die aansluit bij de gevolgde opleidingsrichting dan UM'ers die vijf en tien jaar geleden zijn afgestudeerd. Waarschijnlijk zijn hier twee tegengestelde krachten aan het werk. Voor recent afgestudeerden kan het 
enige tijd duren voordat men een passende baan heeft gevonden. Anderzijds waaieren alumni, naarmate de loopbaan vordert, steeds meer uit over de arbeidsmarkt. Hierbij kan bijvoorbeeld gedacht worden aan allerlei managementachtige functies.

Eerdere metingen hebben laten zien dat vrijwel alle medici een baan vinden die qua richting aansluit bij de gevolgde opleiding. Dit beeld is onveranderd. Bijna alle medici in de verschillende stadia van de loopbaan hebben in 2005 een baan in de eigen richting. Dit geldt in mindere mate voor alumni van andere faculteiten van de UM. Onder economen en juristen ligt het aandeel alumni met een baan die qua richting aansluit bij de gevolgde opleiding zo rond de 60 à 70 procent. Voor gezondheidswetenschappers geldt dat onder recent afgestudeerden het aandeel met een baan die aansluit op de gevolgde opleidingsrichting vrij hoog is, terwijl dit aandeel daalt naarmate de loopbaan van gezondheidswetenschappers vordert.

Tabel 2.6

Werk in eigen of verwante richting in procenten per afstudeercohort, 2005

$\begin{array}{cccccccc} & \text { FdCW } & \text { FdEWB } & \text { FdG } & \text { FdGW } & \text { FdP } & \text { FdR } & \text { Totaal } \\ 2002-2003 & 33 & 71 & 97 & 77 & 80 & 65 & 74 \\ 1998-1999 & \text { n.v.t. } & 64 & 100 & 72 & \text { n.v.t. } & 75 & 76 \\ 1993-1994 & \text { n.v.t. } & 57 & 100 & 68 & \text { n.v.t. } & 73 & 72\end{array}$

Bron: ROA

Figuur 2.5

Aandeel afgestudeerden met een baan die aansluit bij de eigen of verwante opleidingsrichting één, vijf en tien jaar na afstuderen, 2001-2005

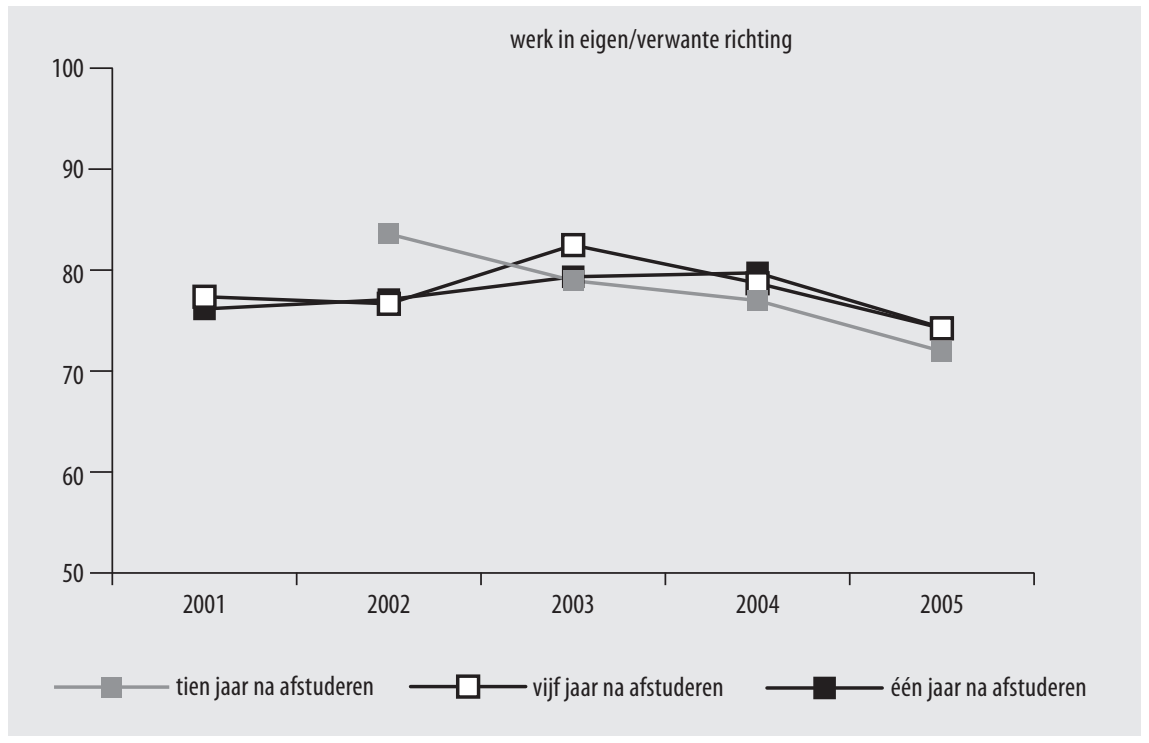

De trendcijfers in figuur 2.5 laten zien dat in de afgelopen jaren steeds minder alumni van de UM een baan hebben gevonden die aansluit bij de gevolgde opleidingsrich- 
ting. Dit geldt voor recent afgestudeerden, voor afgestudeerden die vijf jaar eerder de opleiding hebben verlaten en in het bijzonder voor afgestudeerden die tien jaar eerder de opleiding hebben verlaten. Voor deze laatste groep geldt dat in 2002 in totaal 84 procent van de alumni een baan heeft die aansluit bij de eigen of verwante opleidingsrichting, terwijl dit percentage gestaag is gedaald naar 72 procent in 2005 .

Tabel 2.7

Mediaan bruto uurloon in euro's per afstudeercohort, 2005

$\begin{array}{llllllll} & \text { FdCW } & \text { FdEWB } & \text { FdG } & \text { FdGW } & \text { FdP } & \text { FdR } & \text { Totaal } \\ 2002-2003 & 12,00 & 13,45 & 17,50 & 14,15 & 11,35 & 13,30 & 13,85 \\ 1998-1999 & \text { n.v.t. } & 22,00 & 18,45 & 19,60 & \text { n.v.t. } & 20,20 & 20,20 \\ 1993-1994 & \text { n.v.t. } & 25,95 & 36,05 & 23,10 & \text { n.v.t. } & 24,80 & 25,65\end{array}$

In tabel 2.7 is de mediaan van het bruto uurloon weergegeven voor Maastrichtse alumni in de verschillende stadia van de loopbaan. Dit geeft een aardige indicatie van de snelheid waarmee de loopbaan van alumni zich ontwikkeld. De tabel laat zien dat de mediaan van het bruto uurloon van recent afgestudeerden $€ \epsilon_{3}, 85$ bedraagt. De mediaan van het bruto uurloon voor afgestudeerden die vijf jaar geleden zijn afgestudeerd is maar liefst 6,35 euro hoger dan voor recent afgestudeerden. Dit is niet vreemd waarneer je bedenkt dat afgestudeerden van cohort 1998-I999 de UM hebben verlaten op een moment dat de perspectieven op de arbeidsmarkt zeer gunstig zijn. De mediaan van het bruto uurloon van alumni die tien jaar geleden zijn afgestudeerd is weer 5,35 euro hoger dan van alumni die vijf jaar geleden zijn afgestudeerd.

Gezien hun bruto uurloon ontwikkelt de loopbaan van medici zich zeer voorspoedig, vooral tien jaar na afstuderen. Voor afgestudeerde medici is de mediaan van het bruto uurloon tien jaar na afstuderen met $€ 36,05$ duidelijk hoger dan dat van afgestudeerden van andere faculteiten. Vooral het loon van gezondheidswetenschappers blijft (ondanks de wat hogere leeftijd) hierbij achter. Recent afgestudeerde psychologen lijken wat minder goed beloond te worden. Eerder is al aangegeven dat een groot deel van de afgestudeerden van de FdP als AIO werkzaam is. Het salaris van AIO's is relatief laag, wat uiteraard gevolgen heeft voor het hier gepresenteerde bruto uurloon van psychologen.

De trendcijfers in figuur 2.6 laten voor recent afgestudeerden een stijging zien van het bruto uurloon tot en met meting 2004, daarna is deze licht gedaald. ${ }^{3}$ Ook voor afgestudeerden die vijf en tien jaar eerder de opleiding hebben verlaten lijkt de mediaan van het bruto uurloon in 2005 iets te zijn gedaald in vergelijking met eerdere meetjaren.

3. Voor alumni die vijf en tien jaar eerder zijn afgestudeerd zijn geen cijfers bekend voor meting 200 en 2002 
Figuur 2.6

Mediaan bruto uurloon voor afgestudeerden één, vijf en tien jaar na afstuderen, 2001-2005

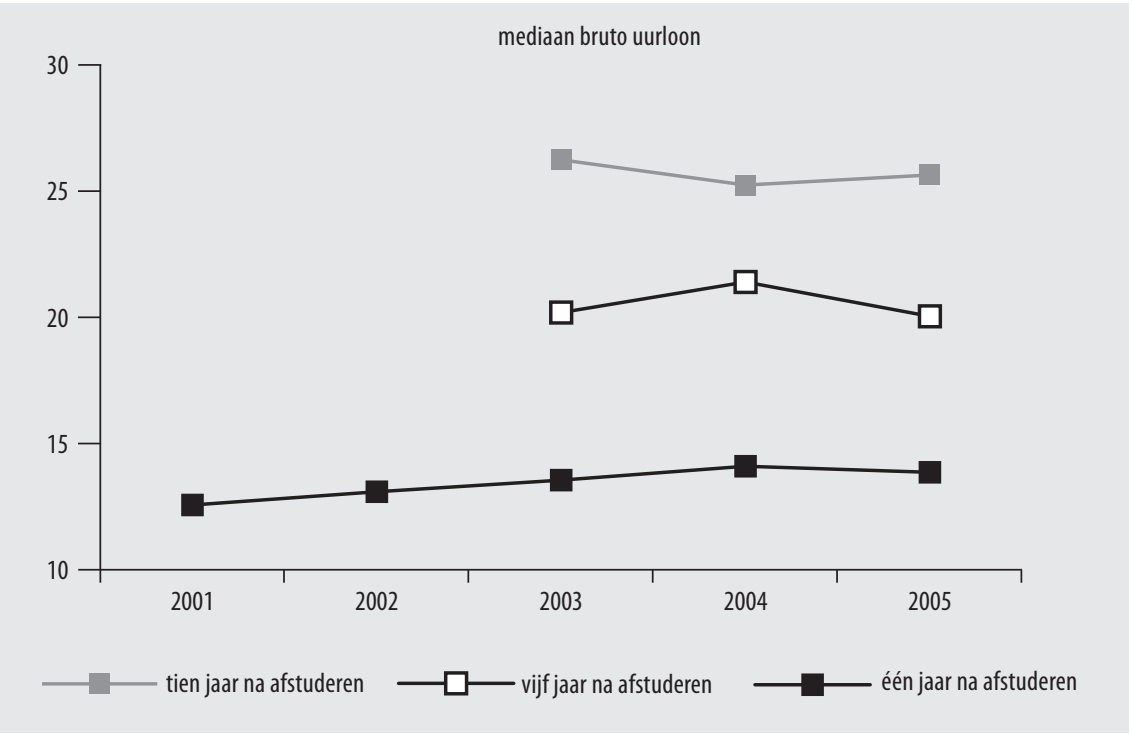

Tot slot van deze paragraaf wordt ingegaan op de vraag in hoeverre alumni in een leidinggevende baan werkzaam zijn. De mate waarin alumni leidinggeven is een goede indicatie van de groei die tijdens een loopbaan wordt doorgemaakt. Uit tabel $2.8 \mathrm{komt}$ naar voren dat leidinggeven nog geen prominente rol speelt in de functies van recent afgestudeerden. In totaal Is procent van de alumni die één jaar geleden is afgestudeerd werkt in een leidinggevende baan. Voor alumni die verder zijn in hun arbeidsloopbaan neemt de betekenis van leidinggeven in het werk toe. Van de alumni die vijf jaar geleden zijn afgestudeerd heeft 35 procent een leidinggevende baan en dit geldt voor bijna de helft van de alumni die tien jaar geleden zijn afgestudeerd. Van de afgestudeerden die vijf en tien jaar geleden zijn afgestudeerd zijn de economen het vaakst werkzaam in een leidinggevende functie.

\section{Tabel 2.8}

Werkzaam in een leidinggevende functie in procenten per afstudeercohort, 2005

$\begin{array}{cccccccc} & \text { FdCW } & \text { FdEWB } & \text { FdG } & \text { FdGW } & \text { FdP } & \text { FdR } & \text { Totaal } \\ 2002-2003 & 28 & 16 & 25 & 10 & 10 & 11 & 15 \\ 1998-1999 & \text { n.v.t. } & 40 & 31 & 31 & \text { n.v.t. } & 38 & 35 \\ 1993-1994 & \text { n.v.t. } & 59 & 56 & 38 & \text { n.v.t. } & 43 & 47\end{array}$

Bron: ROA

\subsection{Competenties}

De verwerving van competenties heeft recentelijk veel aandacht gekregen van beleidsmakers en onderzoekers. De vraag die daarbij naar voren komt is in hoeverre afge- 
studeerden in de opleiding in voldoende mate worden voorzien van competenties die nodig zijn voor de arbeidsmarkt? Tegenwoordig worden competenties die afgestudeerden hebben verworven in de opleiding dan ook beschouwd als een belangrijke indicator van de opbrengsten van opleidingen.

In deze paragraaf staat het vereiste niveau en het eigen niveau van competenties centraal. In tabel 2.9 zijn 25 competenties die in het werk van belang kunnen zijn weergegeven. Hierbij is eerst het vereist niveau van deze 25 competenties weergegeven. Het vereiste niveau geeft voor Maastrichtse alumni aan in welke mate de 25 competenties worden gevraagd op de arbeidsmarkt. Voor de bepaling hiervan is aan de alumni gevraagd voor elke competentie het niveau aan te geven dat vereist is in de huidige functie (op een vijfpuntschaal lopend van 'matig' tot 'uitmuntend'). De tabel vermeldt het percentage afgestudeerden waarvan het vereist niveau van de competentie goed of uitmuntend is (antwoordcategorie 4 en 5). Dit is gedaan voor Maastrichtse alumni die één, vijf en tien jaar eerder de opleiding hebben verlaten.

In tabel 2.9 is hiernaast het eigen niveau van competenties gelegd. Aan de alumni is voor dezelfde 25 competenties gevraagd het eigen niveau van de competenties aan te geven (ook op een vijfpuntschaal lopend van 'matig' tot 'uitmuntend'). De tabel vermeldt het percentage afgestudeerden waarvan het eigen niveau van de competentie goed of uitmuntend is (antwoordcategorie 4 en 5 ).

Uit tabel 2.9 blijkt allereerst dat de competenties zelfstandig werkzaamheden uitvoeren, anderen duidelijk maken wat je bedoelt en logisch redeneren het vaakst worden vereist in de banen van recent afgestudeerden. Van de alumni die één jaar geleden zijn afgestudeerd zegt tenminste 80 procent dat een goed of uitmuntend niveau van deze competenties wordt vereist in de huidige baan. Daarnaast wordt ook vaak een goed of uitmuntend niveau vereist van de competenties informatie vergaren, verbanden leggen tussen verschillende zaken, hoofd- van bijzaken onderscheiden en onder druk goed functioneren in de banen van recent afgestudeerden (aandeel goed/uitmuntend tenminste 75 procent).

Het eigen niveau van alumni die één jaar geleden zijn afgestudeerd laat zien dat competenties die vaak worden vereist in het werk ook door alumni goed of uitmuntend worden beheerst. Het vereist niveau is zelden veel hoger dan het eigen niveau van competenties. Het lijkt er eerder op dat afgestudeerden van de UM die één jaar geleden zijn afgestudeerd eerder een surplus dan een tekort aan competenties hebben in de huidige baan. Opvallend detail hierbij is dat het eigen niveau van de competentie in buitenlandse talen communiceren veel hoger is dan het vereist niveau in de baan.

Voor alumni die vijf en tien jaar geleden aan de UM zijn afgestudeerd komt een vergelijkbaar beeld naar voren als voor recent afgestudeerde alumni. Ook voor alumni die verder zijn gevorderd in de loopbaan geldt dat vaak een goed of uitmuntend niveau wordt vereist van de competenties zelfstandig werkzaamheden uitvoeren, anderen 
duidelijk maken wat je bedoelt, logisch redeneren, informatie vergaren, verbanden leggen tussen verschillende zaken, hoofd- van bijzaken onderscheiden en onder druk goed functioneren. Het belang van deze competenties is nog verder toegenomen in de latere stadia van de loopbaan. Daarnaast worden in de latere stadia van de loopbaan ook de competenties problemen en kansen signaleren, problemen te analyseren en op te lossen en productief met anderen samenwerken vaak op een hoog niveau vereist in het werk (aandeel goed/uitmuntend tenminste 75 procent).

\section{Tabel 2.9}

Vereiste en eigen niveau competenties (\% goed/uitmuntend) per afstudeercohort, 2005

\begin{tabular}{|c|c|c|c|c|c|c|}
\hline & \multicolumn{2}{|c|}{$2002-2003$} & \multicolumn{2}{|c|}{ 1998-1999 } & \multicolumn{2}{|c|}{ 1993-1994 } \\
\hline & $\begin{array}{l}\text { vereist } \\
\text { niveau }\end{array}$ & $\begin{array}{l}\text { eigen } \\
\text { niveau }\end{array}$ & $\begin{array}{l}\text { vereist } \\
\text { niveau }\end{array}$ & $\begin{array}{l}\text { eigen } \\
\text { niveau }\end{array}$ & $\begin{array}{l}\text { vereist } \\
\text { niveau }\end{array}$ & $\begin{array}{l}\text { eigen } \\
\text { niveau }\end{array}$ \\
\hline \multicolumn{7}{|l|}{ Kennis van: } \\
\hline het eigen vakgebied & 65 & 64 & 76 & 72 & 67 & 72 \\
\hline andere vakgebieden & 43 & 38 & 40 & 33 & 37 & 39 \\
\hline \multicolumn{7}{|l|}{ Vermogen om: } \\
\hline vakkennis in de praktijk toe te passen & 64 & 64 & 75 & 77 & 69 & 76 \\
\hline ICT te gebruiken & 57 & 64 & 56 & 59 & 55 & 56 \\
\hline in buitenlandse talen te communiceren & 40 & 61 & 39 & 54 & 30 & 48 \\
\hline informatie te vergaren & 79 & 87 & 85 & 87 & 80 & 84 \\
\hline problemen en kansen te signaleren & 74 & 73 & 85 & 84 & 82 & 81 \\
\hline verbanden leggen tussen verschillende zaken & 76 & 81 & 88 & 85 & 86 & 90 \\
\hline hoofdzaken van bijzaken te onderscheiden & 79 & 78 & 90 & 83 & 90 & 88 \\
\hline logisch te redeneren & 80 & 87 & 88 & 92 & 86 & 92 \\
\hline problemen te analyseren en op te lossen & n.v.t. & n.v.t. & 88 & 89 & 88 & 90 \\
\hline conform budget, planning, richtlijnen werken & 56 & 55 & 61 & 57 & 65 & 69 \\
\hline onder druk goed te functioneren & 75 & 75 & 81 & 78 & 83 & 82 \\
\hline knopen door te hakken & 63 & 60 & 71 & 68 & 68 & 70 \\
\hline nieuwe ideeën en oplossingen te bedenken & 64 & 72 & 68 & 70 & 70 & 72 \\
\hline nieuwe dingen te leren & 74 & 91 & 71 & 85 & 65 & 82 \\
\hline aan anderen duidelijk te maken wat u bedoelt & 82 & 79 & 92 & 83 & 91 & 84 \\
\hline productief met anderen samen te werken & 73 & 85 & 80 & 82 & 80 & 86 \\
\hline capaciteiten van anderen aan te spreken & 53 & 55 & 60 & 58 & 69 & 68 \\
\hline zelfstandig de werkzaamheden uit te voeren & 87 & 89 & 91 & 93 & 94 & 96 \\
\hline een presentatie te houden voor een publiek & n.v.t. & n.v.t. & 58 & 66 & 58 & 66 \\
\hline \multicolumn{7}{|l|}{ Bereidheid om: } \\
\hline nek uit te steken & 56 & 63 & 56 & 67 & 57 & 70 \\
\hline (eigen) ideeën ter discussie te stellen & 62 & 66 & 66 & 68 & 64 & 71 \\
\hline op te komen voor eigen standpunt & 66 & 69 & 76 & 76 & 74 & 76 \\
\hline begrip te tonen voor andere standpunten & 71 & 77 & 80 & 79 & 79 & 80 \\
\hline
\end{tabular}

Bron: ROA

n.v.t = niet van toepassing, deze competenties zijn niet gevraagd aan alumni die één jaar eerder de opleiding aan de UM hebben verlaten

Uit het eigen niveau van competenties blijkt vervolgens dat de alumni over het algemeen meegroeien met hun baan. Voor het merendeel van de competenties geldt dat het eigen niveau van de competenties in vergelijkbare mate toeneemt als het vereist niveau van de competenties in de baan. Maar dit geldt niet voor alle competenties. Zo blijkt dat de het eigen niveau van de competentie aan anderen duidelijk maken wat je bedoelt in de latere stadia van de loopbaan iets achterblijft bij het vereist niveau. 
Hetzelfde zien we in iets mindere mate bij de competenties hoofd- van bijzaken onderscheiden.

In hoofdstuk 4 zal nader worden ingegaan op de vraag welke groepen Maastrichtse alumni bij het uitvoeren van hun werkzaamheden (eventueel) tekorten ervaren in competenties. Hiertoe worden per faculteit verschillen in vereist en eigen niveau van competenties van Maastrichtse alumni bekeken.

De UM staat bekend om zijn probleemgestuurd onderwijs (PGO). Aan alumni die vijf en tien jaar eerder de opleiding hebben verlaten, zijn dan ook een tweetal vragen gesteld omtrent de relatie tussen PGO en de bovenstaande competenties. Eerst is gevraagd om van de 25 competenties maximaal 3 competenties te noemen waarvan PGO een voordeel is geweest. In tabel 2.IO staan de vijf competenties vermeld die het vaakst werden genoemd.

De competentie waarvan oud-studenten van de UM vinden dat PGO vooral een voordeel is geweest, is de competentie vermogen om problemen te analyseren en op te lossen. Deze wordt duidelijk het vaakst genoemd (door $47 \%$ van de alumni). Daarnaast geven Maastrichtse alumni relatief vaak aan dat PGO een voordeel is geweest voor het vermogen om productief met anderen samen te werken en informatie vergaren. Overigens zeggen economen duidelijk minder vaak dat PGO een voordeel is geweest voor het vermogen om informatie te vergaren dan afgestudeerden van andere faculteiten. Tot slot blijkt dat PGO redelijk vaak een voordeel is geweest voor de competenties vermogen om verbanden te leggen tussen verschillende zaken en hoofd- van bijzaken onderscheiden.

\section{Tabel 2.10}

De vijf vaakst genoemde competenties waarvan afgestudeerden vinden dat PGO een voordeel is geweest, in procenten, 2005

\begin{tabular}{|c|c|c|c|c|c|}
\hline & FdEWB & $\mathrm{FdG}$ & FdGW & $\mathrm{FdR}$ & Totaa \\
\hline \multicolumn{6}{|l|}{ Cohort 1998-1999 } \\
\hline problemen te analyseren en op te lossen & 44 & 49 & 40 & 61 & 47 \\
\hline productief met anderen samen te werken & 40 & 31 & 29 & 16 & 30 \\
\hline informatie te vergaren & 10 & 46 & 35 & 34 & 30 \\
\hline verbanden leggen tussen verschillende zaken & 12 & 21 & 24 & 39 & 23 \\
\hline hoofdzaken van bijzaken te onderscheiden & 16 & 16 & 22 & 22 & 19 \\
\hline \multicolumn{6}{|l|}{ Cohort 1993-1994 } \\
\hline problemen te analyseren en op te lossen & 37 & 49 & 49 & 51 & 47 \\
\hline informatie te vergaren & 19 & 42 & 39 & 39 & 35 \\
\hline productief met anderen samen te werken & 37 & 22 & 35 & 21 & 31 \\
\hline hoofdzaken van bijzaken te onderscheiden & 19 & 24 & 21 & 27 & 22 \\
\hline verbanden leggen tussen verschillende zaken & 13 & 24 & 26 & 18 & 21 \\
\hline
\end{tabular}

Aan de alumni is vervolgens gevraagd om van de 25 competenties maximaal 3 competenties te noemen waarvan PGO een nadeel is geweest (zie tabel 2.II). Hier wordt door de alumni vermogen om conform budget, planning, richtlijnen te werken het 
vaakst genoemd. Dit geldt voor beide cohorten. Met andere woorden; volgens oudstudenten van de UM draagt PGO in mindere mate bij aan de competentie vermogen om conform budget, planning, richtlijnen te werken. Daarnaast worden de competenties ICT gebruiken, in buitenlandse talen communiceren, knopen doorhakken en onder druk goed functioneren het vaakst genoemd. Daarbij geldt dat vooral alumni van de faculteiten FdGW en FdR zeggen dat PGO een nadeel is geweest voor de competentie vermogen om in buitenlandse talen te communiceren.

\section{Tabel 2.11}

De vijf vaakst genoemde competenties waarvan afgestudeerden vinden dat PGO een nadeel is geweest, in procenten, 2005

Cohort 1998-1999
conform budget, planning, richtlijnen werken
ICT te gebruiken
in buitenlandse talen te communiceren
knopen door te hakken
onder druk goed te functioneren
Cohort 1993-1994
conform budget, planning, richtlijnen werken
ICT te gebruiken
onder druk goed te functioneren
in buitenlandse talen te communiceren
knopen door te hakken
Bron: ROA

$\begin{array}{rcccc}\text { FdEWB } & \text { FdG } & \text { FdGW } & \text { FdR } & \text { Totaal } \\ 24 & 31 & 27 & 21 & 26 \\ 31 & 14 & 22 & 27 & 23 \\ 3 & 17 & 34 & 25 & 20 \\ 19 & 14 & 14 & 15 & 16 \\ 15 & 15 & 15 & 13 & 15\end{array}$

$\begin{array}{lllll}23 & 31 & 31 & 26 & 28 \\ 19 & 25 & 21 & 30 & 23 \\ 30 & 21 & 20 & 13 & 21 \\ 12 & 17 & 23 & 26 & 20 \\ 12 & 13 & 25 & 15 & 18\end{array}$

Naast het PGO staat de UM ook bekend om zijn internationale karakter. Aan de oud-studenten van de UM is gevraagd aan te geven in hoeverre het internationale karakter van de UM heeft bijgedragen aan (I) het vermogen om in buitenlandse talen te communiceren (2) verruiming van mijn blikveld (3) mijn persoonlijke ontwikkeling. Deze drie vragen zijn gemeten op een vijfpuntschaal die loopt van 'helemaal niet' $\mathrm{t} / \mathrm{m}$ 'in sterke mate'. De resultaten hiervan zijn weergegeven in tabel 2.12 (voor cohort I998-1999) en in tabel 2.13 (voor cohort 1993-1994). Vermeld is het aandeel alumni dat aangeeft dat het internationale karakter heeft bijgedragen (antwoordcategorie 4 of 5 ).

Tabel 2.12

Aandeel afgestudeerden dat zegt dat het internationale karakter van de UM heeft bijgedragen aan......, in procenten, cohort 1998-1999, 2005

$\begin{array}{lccccc} & \text { FdEWB } & \text { FdG } & \text { FdGW } & \text { FdR } & \text { Totaal } \\ \text { vermogen om in buitenlandse talen inhoudelijk te communiceren } & 66 & 24 & 10 & 20 & 31 \\ \text { verruiming van mijn blikveld } & 60 & 34 & 24 & 28 & 37 \\ \text { mijn persoonlijke ontwikkeling } & 62 & 39 & 31 & 38 & 43\end{array}$

Bron: ROA

De tabellen 2.I2 en 2.13 laten duidelijke verschillen zien tussen afgestudeerden van de FdEWB en afgestudeerden van andere faculteiten. Vooral afgestudeerden van de FdEWB vinden namelijk dat het internationale karakter van de UM heeft bijgedragen aan het in buitenlandse talen communiceren, de verruiming van het blikveld 
en de persoonlijke ontwikkeling. Afgestudeerden van de andere faculteiten denken hier vaak heel anders over. Vooral als het gaat om communiceren in buitenlandse talen blijkt dat een beperkt deel van de afgestudeerden van de FdG, FdGW en FdR vindt dat het internationale karakter van de UM hieraan heeft bijgedragen.

Tabel 2.13

Aandeel afgestudeerden dat zegt dat het internationale karakter van de UM heeft bijgedragen aan......, in procenten, cohort 1993-1994, 2005

$\begin{array}{lccccc} & \text { FdEWB } & \text { FdG } & \text { FdGW } & \text { FdR } & \text { Totaal } \\ \text { vermogen om in buitenlandse talen inhoudelijk te communiceren } & 52 & 16 & 7 & 18 & 20 \\ \text { verruiming van mijn blikveld } & 50 & 24 & 20 & 29 & 29 \\ \text { mijn persoonlijke ontwikkeling } & 58 & 28 & 26 & 33 & 34\end{array}$
Bron: ROA

Het bovenstaande verschil vinden we ook terug in tabel 2.I4. Hierin is het aandeel afgestudeerden vermeld dat zegt in de huidige baan te profiteren van het internationale karakter van de UM, voor de cohorten 1998-1999 en 1993-1994. Ook hier geldt dat afgestudeerde economen dit veel vaker vinden dan afgestudeerden van andere faculteiten van de UM. Waarschijnlijk speelt hierbij mee dat afgestudeerden economen vaker terecht komen in banen met een internationaal karakter dan andere afgestudeerden. De vraag is in hoeverre het internationale karakter van de UM en Engelstalig onderwijs relevant is voor studenten van andere faculteiten dan economie? Verder wordt duidelijk dat alumni van de UM, met uitzondering van alumni van de FdR, in de latere stadia van de loopbaan minder vaak aangeven nog te profiteren van het internationale karakter van de UM.

Tabel 2.14

Het aandeel afgestudeerden dat zegt in de huidige baan te profiteren van het internationale karakter van de UM.

$\begin{array}{llllll} & \text { FdEWB } & \text { FdG } & \text { FdGW } & \text { FdR } & \text { Totaal } \\ \text { Cohort 1998-1999 } & 75 & 35 & 25 & 33 & 47 \\ \text { Cohort 1993-1994 } & 55 & 18 & 17 & 44 & 33\end{array}$

Bron: ROA

\subsection{Een evaluatie van de baan, studiekeuze en ontwikkelingsmogelijkheden}

In hoeverre zijn Maastrichtse alumni tevreden met hun huidige baan? Welk deel van de in de opleiding verworven kennis en vaardigheden zijn nu verouderd. Zouden de alumni opnieuw voor dezelfde opleiding aan de UM kiezen? In deze paragraaf komen deze vragen aan bod.

Afgestudeerden hebben op een vijfpuntschaal (van 'zeer ontevreden' tot 'zeer tevreden') kunnen aangeven hoe tevreden ze zijn met hun huidige baan. Tabel 2.15 vermeldt het procentuele aandeel van de alumni dat (zeer) tevreden is met de huidige baan (antwoordcategorie 4 of 5). Over het algemeen geldt dat afgestudeerden van de UM tevreden zijn met hun huidige functie. Van de recent afgestudeerden zegt 69 procent 
(zeer) tevreden te zijn over de huidige baan. Voor alumni die vijf en tien jaar geleden zijn afgestudeerd ligt dit aandeel iets hoger. Medici zijn over het algemeen het vaakst tevreden met de huidige baan. Dit is niet verassend gezien het specifieke karakter van de opleiding, het duidelijke beroepsbeeld en de goede aansluiting tussen opleiding en baan. Recent afgestudeerde economen en gezondheids-wetenschappers zijn wat minder vaak tevreden met de huidige functie. Opvallend is dat dit bij economen vooral geldt voor degenen die tien jaar eerder zijn afgestudeerd. Wellicht speelt hierbij mee dat deze alumni halverwege de jaren '9o van de vorige eeuw de arbeidsmarkt hebben betreden, toen de situatie op de arbeidsmarkt relatief ongunstig was. De situatie op de arbeidsmarkt kan gevolgen hebben voor het verdere verloop van de loopbaan. Eerder in dit hoofdstuk is al gebleken dat relatief veel Maastrichtse alumni tien jaar na afstuderen werkzaam zijn in banen beneden WO-niveau.

Tabel 2.15

(Zeer) tevreden met de huidige baan in procenten per afstudeercohort, 2005

$\begin{array}{cccccccc} & \text { FdCW } & \text { FdEWB } & \text { FdG } & \text { FdGW } & \text { FdP } & \text { FdR } & \text { Totaal } \\ 2002-2003 & 48 & 68 & 82 & 64 & 71 & 73 & 69 \\ 1998-1999 & \text { n.v.t. } & 74 & 89 & 78 & \text { n.v.t. } & 81 & 79 \\ 1993-1994 & \text { n.v.t. } & 67 & 82 & 74 & \text { n.v.t. } & 80 & 75\end{array}$

Bron: ROA

Tabel 2.16

Opleiding biedt een (zeer) goede basis om te starten op de arbeidsmarkt in procenten per afstudeercohort, 2005

$\begin{array}{cccccccc} & \text { FdCW } & \text { FdEWB } & \text { FdG } & \text { FdGW } & \text { FdP } & \text { FdR } & \text { Totaal } \\ 2002-2003 & 13 & 77 & 99 & 38 & 42 & 64 & 59 \\ 1998-1999 & \text { n.v.t. } & 89 & 95 & 65 & \text { n.v.t. } & 79 & 80 \\ 1993-1994 & \text { n.v.t. } & 64 & 88 & 50 & \text { n.v.t. } & 54 & 60\end{array}$

Bron: ROA

Aan afgestudeerden van de UM is gevraagd om op een vijfpuntschaal (van 'helemaal niet' $t / m$ 'in sterke mate') aan te geven in welke mate de opleiding aan de UM hen een goede basis biedt om te starten op de arbeidsmarkt. In tabel 2.16 is vermeld welk deel van de alumni vindt dat de opleiding een goede basis biedt om te starten op de arbeidsmarkt (antwoordcategorie 4 en 5). Van de alumni die één jaar geleden zijn afgestudeerd zegt $59 \%$ dat de opleiding een goede basis biedt om te starten op de arbeidsmarkt. Er bestaan wat dit betreft verschillen tussen de afgestudeerden van de faculteiten. Met name afgestudeerden van de FdG (99 procent) geven aan dat de opleiding hen startbekwaam heeft gemaakt voor de arbeidsmarkt. Dit geldt in veel mindere mate voor afgestudeerden van de FdCW, FdGW en FdP, waar minder dan de helft van de afgestudeerden vindt dat de opleiding voor hen een goede basis biedt om te starten op de arbeidsmarkt. Overigens zijn alumni die vijf jaar geleden zijn afgestudeerd positiever over de mate waarin de opleiding hen startbekwaam heeft gemaakt voor de opleiding. Maar dit geldt niet voor alumni die tien jaar eerder de opleiding aan de UM hebben verlaten. Slechts 60 procent van de alumni die tien jaar geleden de opleiding hebben verlaten, vindt dat de opleiding een goede basis biedt om te starten 
op de arbeidsmarkt. Zoals eerder aangegeven hebben alumni die tien jaar eerder zijn afgestudeerd de arbeidsmarkt betreden op het moment dat deze relatief ongunstig was. Daarbij laten de alumni blijken dat de gevolgde opleiding onder ongunstige omstandigheden een minder goede basis biedt om te starten op de arbeidsmarkt.

Gedurende de loopbaan worden hoger opgeleiden voortdurend geconfronteerd met veranderingen in hun beroep. Dit betekent dat opleidingen - naast het verschaffen van een goede basis om te starten op de arbeidsmarkt - alumni moeten voorzien van kennis en vaardigheden om zich verder te kunnen ontwikkelen. Aan de alumni is gevraagd om op een vijfpuntschaal (van 'helemaal niet' $t / m$ 'in sterke mate') aan te geven in welke mate de opleiding een basis biedt om kennis en vaardigheden verder te ontwikkelen. Tabel 2.17 laat het aandeel alumni zien dat zegt dat de opleiding een (zeer) goede basis verschaft om kennis en vaardigheden verder te ontwikkelen (antwoordcategorie 4 of 5). Hieruit blijkt dat alumni wat dit betreft positiever zijn dan over hun startbekwaamheid. Alumni van de UM zijn namelijk zeer te spreken over hun vermogen om zich beroepsmatig verder te kunnen ontwikkelen. Dit geldt oor al de drie cohorten. Verder zien we dat de verschillen tussen de faculteiten vrij gering zijn. Alumni van de FdG zijn over het algemeen het vaakst tevreden over de mate waarin de opleiding een goede basis biedt om nieuwe kennis en vaardigheden op te doen.

Tabel 2.17

Opleiding biedt een (zeer) goede basis om kennis en vaardigheden verder te ontwikkelen in procenten per afstudeercohort, 2005

$\begin{array}{cccccccc} & \text { FdCW } & \text { FdEWB } & \text { FdG } & \text { FdGW } & \text { FdP } & \text { FdR } & \text { Totaal } \\ 2002-2003 & 72 & 89 & 96 & 77 & 82 & 81 & 84 \\ 1998-1999 & \text { n.v.t. } & 91 & 94 & 80 & \text { n.v.t. } & 91 & 88 \\ 1993-1994 & \text { n.v.t. } & 85 & 95 & 84 & \text { n.v.t. } & 84 & 86\end{array}$

Bron: ROA

Aan de alumni die vijf en tien jaar geleden zijn afgestudeerd is gevraagd een inschatting te geven welk deel van de kennis en vaardigheden die ze in de huidige baan gebruiken, is verworven na het verlaten van de opleiding (in procenten). Alumni die vijf jaar geleden zijn afgestudeerd geven aan dat 58 procent van de kennis en vaardigheden die ze in het werk gebruiken na het verlaten van de opleiding zijn verworven. Voor afgestudeerden die tien jaar geleden zijn afgestudeerd is dit percentage met 57 procent vrijwel gelijk. Dit lijkt er op te wijzen een redelijk deel van de kennis en vaardigheden die zijn opgedaan in de opleiding relevant blijven, ook in latere stadia van de carrière. Dit blijkt ook uit tabel 2.I9. In deze tabel is vermeld welk deel van de kennis en vaardigheden die in de opleiding is opgedaan volgens inschatting van de afgestudeerden is verouderd (in procenten). Hieruit blijkt dat afgestudeerden die vijf jaar geleden zijn afgestudeerd zeggen dat 27 procent van de in de opleiding verworven kennis en vaardigheden nu is verouderd. Bij alumni die tien jaar geleden zijn afgestudeerd is dit 37 procent. Overigens geven afgestudeerden van de FdR vaker aan dat de 
in de opleiding verworven kennis en vaardigheden zijn verouderd dan afgestudeerden van andere faculteiten.

Tabel 2.18

Aandeel van de kennis en vaardigheden die volgens eigen inschatting na het verlaten van de opleiding is verworven in procenten per afstudeercohort, 2005

$\begin{array}{cccccc} & \text { FdEWB } & \text { FdG } & \text { FdGW } & \text { FdR } & \text { Totaal } \\ 1998-1999 & 62 & 56 & 55 & 58 & 58 \\ 1993-1994 & 61 & 53 & 55 & 61 & 57\end{array}$

Bron: ROA

Tabel 2.19

Aandeel kennis en vaardigheden in de opleiding opgedaan die volgens eigen inschatting nu is verouderd in procenten per afstudeercohort, 2005

$\begin{array}{cccccc} & \text { FdEWB } & \text { FdG } & \text { FdGW } & \text { FdR } & \text { Totaal } \\ 1998-1999 & 22 & 22 & 28 & 42 & 27 \\ 1993-1994 & 34 & 25 & 36 & 47 & 36\end{array}$

Bron: ROA

Aan de alumni is gevraagd of ze, achteraf bezien, opnieuw voor dezelfde opleiding zouden kiezen aan de Universiteit Maastricht. Het betreft hier een belangrijke indicator voor de mate van tevredenheid met de huidige situatie. De studiekeuze heeft een belangrijke invloed op de beroepsloopbaan en de latere levensloop. Alumni met betaald werk die zeggen niet opnieuw voor dezelfde opleiding te kiezen, geven hiermee aan dat ze wellicht een andere werkplek voor ogen hebben gehad toen zij aan de studie begonnen. Dat kan een werkplek zijn die inhoudelijk beter bij hen past of die hen beter in staat stelt de levensdoelen te realiseren. Alumni zonder betaald werk zouden wellicht met een andere studie wel werk hebben kunnen vinden.

De tabellen 2.20a tot en met 2.20c laten zien hoe alumni van de UM op hun studiekeuze terugkijken. Hieruit blijkt dat het merendeel van de alumni van de UM tevreden is over de destijds gemaakte studiekeuze. Ongeveer driekwart van de alumni geeft aan dat ze, achteraf bezien, opnieuw voor dezelfde studie aan de UM zouden kiezen. Economen, medici en juristen kijken over het algemeen het vaakst met voldoening terug op de opleiding. Gezondheidswetenschappers geven daarentegen veruit het vaakst aan dat ze achteraf liever een andere opleiding zouden hebben gekozen. Bovendien neemt dit aandeel gedurende de loopbaan toe. Gezondheidswetenschappers noemen vaak geneeskunde en psychologie als mogelijke opleidingen die ze liever hadden gevolgd. Voor recent afgestudeerden geldt daarnaast dat relatief weinig cultuurwetenschappers en psychologen aangeven dat ze achteraf opnieuw dezelfde studie aan de UM zouden volgen. Een aantal Maastrichtse alumni geeft aan dezelfde opleiding liever aan een andere universiteit gevolgd te hebben. Het betreft hier met name alumni van de FdG en FdP. Dit laatste blijkt ook te gelden voor eerdere metingen. 


\section{Tabel 2.20a}

De studiekeuze achteraf één jaar na afstuderen in procenten cohort 2002-2003, 2005 (Zou u de opleiding opnieuw kiezen?)

Ja, en opnieuw aan de UM
Ja, maar aan een andere universiteit
Nee, een andere opleiding
Nee, ik zou niet zijn gaan studeren

$\begin{array}{ccccccc}\text { FdCW } & \text { FdEWB } & \text { FdG } & \text { FdGW } & \text { FdP } & \text { FdR } & \text { Totaal } \\ 68 & 77 & 86 & 72 & 65 & 77 & 75 \\ 4 & 5 & 14 & 3 & 18 & 7 & 7 \\ 28 & 17 & 0 & 24 & 16 & 15 & 17 \\ 0 & 1 & 0 & 0 & 0 & 0 & 0\end{array}$

Bron: ROA

Tabel 2.20b

De studiekeuze achteraf vijf jaar na afstuderen in procenten cohort 1998-1999, 2005 (Zou u de opleiding opnieuw kiezen?)

$\begin{array}{lcrrrr} & \text { FdEWB } & \text { FdG } & \text { FdGW } & \text { FdR } & \text { Totaal } \\ \text { Ja, en opnieuw aan de UM } & 78 & 86 & 59 & 77 & 73 \\ \text { Ja, maar aan een andere universiteit } & 3 & 8 & 5 & 6 & 5 \\ \text { Nee, een andere opleiding } & 18 & 6 & 37 & 17 & 22 \\ \text { Nee, ik zou niet zijn gaan studeren } & 1 & 0 & 0 & 0 & 0\end{array}$

Bron: ROA

\section{Tabel 2.20C}

De studiekeuze achteraf tien jaar na afstuderen in procenten cohort 1993-1994, 2005 (Zou u de opleiding opnieuw kiezen?)

$\begin{array}{lrrrrr} & \text { FdEWB } & \text { FdG } & \text { FdGW } & \text { FdR } & \text { Totaal } \\ \text { Ja, en opnieuw aan de UM } & 81 & 95 & 55 & 79 & 72 \\ \text { Ja, maar aan een andere universiteit } & 0 & 0 & 2 & 5 & 2 \\ \text { Nee, een andere opleiding } & 19 & 5 & 43 & 14 & 26 \\ \text { Nee, ik zou niet zijn gaan studeren } & 0 & 0 & 0 & 2 & 0\end{array}$

Bron: ROA

Figuur 2.7

Aandeel alumni dat achteraf zegt opnieuw te kiezen voor dezelfde opleiding aan de UM één, vijf en tien jaar na afstuderen, 2001-2005

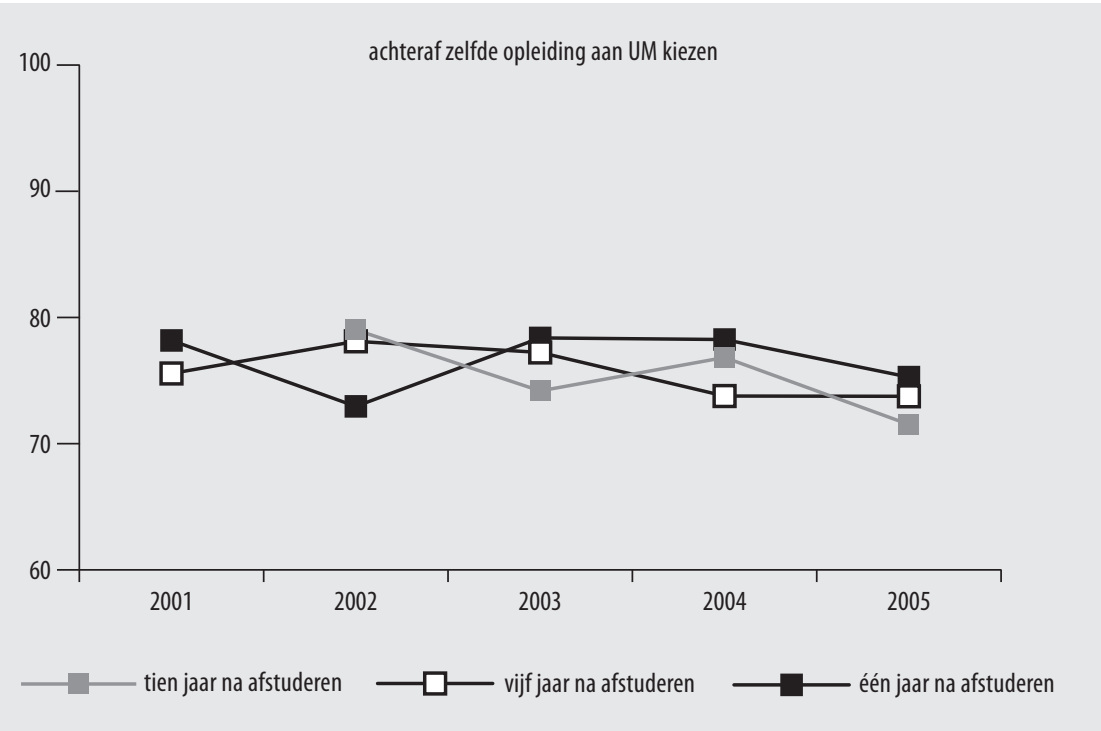


Tot slot is in figuur 2.7 het aandeel Maastrichtse alumni vermeldt dat aangeeft achteraf bezien opnieuw te kiezen voor dezelfde opleiding aan de UM, voor de periode 200I2005. Hieruit blijkt dat dit aandeel in de periode 200I-2005 vrij stabiel is. Voor zowel recent afgestudeerden als voor afgestudeerden die vijf en tien jaar eerder de UM hebben verlaten, fluctueert het aandeel alumni dat opnieuw dezelfde opleiding aan de UM zou kiezen rond de $75 \%$.

\subsection{Conclusie}

Voor Maastrichtse alumni die recent de UM hebben verlaten is de situatie op de arbeidsmarkt minder gunstig geworden. In 2005 zeggen alumni die één jaar eerder zijn afgestudeerd vaker werkloos te zijn dan de jaren ervoor. Vooral veel recent afgestudeerde economen, juristen en psychologen zeggen nu werkloos te zijn. Onder afgestudeerden die vijf en tien jaar geleden de Universiteit Maastricht hebben verlaten, is het aandeel alumni dat aangeeft werkloos te zijn minimaal en vrijwel niet veranderd ten opzichte van de vorige metingen.

Het aandeel recent afgestudeerden met een vaste baan blijft onveranderd ten opzichte van eerdere metingen. Dit aandeel fluctueert in de afgelopen jaren rond de 50 procent. Hetzelfde geldt voor alumni die vijf jaar eerder zijn afgestudeerd, waar het aandeel afgestudeerden met een vaste baan schommelt rond de 80 procent. Onder afgestudeerden die tien jaar eerder de opleiding hebben verlaten, is het aandeel met een vaste baan toegenomen van 82 procent in 2002 naar 92 procent in 2005 .

Maastrichtse alumni gaan in de latere stadia van de loopbaan steeds vaker parttime werken. Dit geldt vooral voor afgestudeerden van de FdG. Van de recent afgestudeerden werken relatief veel afgestudeerden van de faculteiten FdCW en FdGW in deeltijd. De trendcijfers laten zien dat in de afgelopen jaren het aandeel parttimers onder afgestudeerden van de UM is toegenomen.

Het aandeel recent afgestudeerden met een baan op WO-niveau is in 2005 vrijwel onveranderd gebleven. Deze schommelt de afgelopen jaren rond de 7I procent. Voor afgestudeerden die vijf jaar eerder de opleiding hebben verlaten zien we een stijging van het aandeel alumni met een baan op WO-niveau van 67 procent in 200 I naar 77 procent in 2005. Meting 2005 laat voor alumni die tien jaar eerder zijn afgestudeerd een duidelijke trendbreuk zien in het aandeel werkenden met een baan op WOniveau. Tot meting 2004 geldt dat ongeveer 80 procent van de alumni een baan op WO-niveau heeft. In 2005 is dit gedaald naar 70 procent. Waarschijnlijk speelt hierbij mee dat deze laatste groep op een relatief ongunstig moment de arbeidsmarkt hebben betreden. Andere indicaties hiervoor zijn dat relatief veel van deze alumni zeggen dat de opleiding geen goede basis bood om te starten op de arbeidsmarkt. 
Trendcijfers laten zien dat het bruto uurloon van recent afgestudeerden tot en met meting 2004 is gestegen en daarna iets is gedaald. Ook voor afgestudeerden die vijf en tien jaar eerder de opleiding hebben verlaten lijkt het bruto uurloon in 2005 iets te zijn gedaald in vergelijking met eerdere meetjaren. Uit de ontwikkeling van het bruto uurloon blijkt dat vooral de loopbaan van medici het meest voorspoedig verloopt. Afgestudeerde medici verdienen tien jaar na afstuderen duidelijk meer dan afgestudeerden van andere faculteiten.

Aan de alumni is gevraagd voor 25 competenties het eigen niveau hiervan en het vereist niveau in de baan aan te geven. Hieruit blijkt dat de competenties zelfstandig werkzaamheden uitvoeren, anderen duidelijk maken wat je bedoelt en logisch redeneren het vaakst op een hoog niveau (goed of uitmuntend) worden vereist in de banen van recent afgestudeerden. Het eigen niveau van alumni die één jaar geleden zijn afgestudeerd laat zien dat deze competenties door alumni meestal ook goed of uitmuntend worden beheerst. Daarnaast lijkt het er op dat alumni die vijf en tien jaar eerder de opleiding hebben verlaten, meegroeien met hun baan. Dit blijkt wanneer voor deze alumni het eigen niveau en het vereist niveau van competenties naast elkaar worden gelegd. Voor het merendeel van alumni geldt dat het eigen niveau van de competenties in vergelijkbare mate toeneemt als het vereist niveau in de baan. Alléén bij de competenties aan anderen duidelijk maken wat je bedoelt en hoofd- van bijzaken onderscheiden blijft het eigen niveau van de alumni in de latere stadia van de loopbaan iets achter bij het vereist niveau.

Wanneer de alumni wordt gevraagd aan te geven voor welke competenties PGO vooral een voordeel is geweest, dan wordt de competentie vermogen om problemen te analyseren en op te lossen veruit het vaakst genoemd. Wanneer de alumni wordt gevraagd aan te geven voor welke competenties PGO vooral een nadeel is geweest, dan noemen de alumni het vaakst het vermogen om conform budget, planning, richtlijnen te werken.

Het merendeel van de alumni van de UM is tevreden over de destijds gemaakte studiekeuze. Economen, medici en juristen geven het vaakst aan achteraf gezien voor dezelfde opleiding te kiezen. Onder recent afgestudeerden geldt dat cultuurwetenschappers, gezondheidswetenschappers en psychologen wat dit betreft wat minder tevreden zijn. Bovendien neemt onder gezondheidswetenschappers het aandeel afgestudeerden dat zegt liever een andere opleiding te hebben gevolgd toe in de latere stadia van de loopbaan. Gezondheidswetenschappers noemen vaak geneeskunde en psychologie als mogelijke opleidingen die ze liever hadden gevolgd. 


\section{De loopbaan van Maastrichtse alumni}

In dit hoofdstuk wordt ingegaan op de loopbanen van Maastrichtse alumni. Hiervoor maken we gebruik van de longitudinale gegevens die we tot onze beschikking hebben. Door de alumni vaker te benaderen wordt het mogelijk de dynamiek in de loopbanen van de Maastrichtse alumni in kaart te brengen en kunnen de verschillende fasen in de loopbaan in hun onderlinge samenhang worden geanalyseerd. Van het cohort 1993I994 maken we gebruik van de meting één en tien jaar na afstuderen. Van het cohort I998-I999 gebruiken we de meting één jaar en vijf jaar na afstuderen.

In paragraaf 3.I van dit hoofdstuk wordt een eerste beeld geschetst van de loopbaanpatronen van afgestudeerden van de UM. Bekeken wordt het aantal banen en werkgevers van alumni sinds het verlaten van de opleiding. Vervolgens wordt in paragraaf 3.2 met behulp van longitudinale gegevens de loopbanen van Maastrichtse alumni nader geanalyseerd. Centraal hierbij staat de vraag in hoeverre de start van de loopbaan van invloed is op de verdere carrière. Hiertoe worden de verschillende fasen in de loopbaan met elkaar in verband gebracht.

\subsection{Een retrospectieve kijk op loopbanen}

Tabellen 3.Ia en 3.Ib vermelden het aantal banen die Maastrichtse alumni na het verlaten van de opleiding hebben gehad. Dit is inclusief werk als zelfstandige/freelancer en eerdere banen bij de huidige werkgever. De vraag hierbij is of er sprake is van een stabiele loopbaan met een beperkt aantal baanwisselingen? Of wisselt de Maastrichtse alumnus vaak van baan? Verschillende factoren kunnen hierbij een rol spelen. Zo is bekend dat de arbeidsmarktsituatie van invloed is op de mobiliteit van werknemers. Wanneer er weinig vacatures zijn, zal de vrijwillige mobiliteit geringer zijn. Een tekort aan personeel kan daarentegen een positief effect hebben op de vrijwillige mobiliteit, omdat er meer mogelijkheden zijn om de positie te verbeteren. Daarnaast blijkt de mobiliteit gedurende de loopbaan af te nemen. Mensen vinden na verloop van tijd een baan die goed aansluit bij hun wensen en capaciteiten, de baanzekerheid wordt groter en ook andere factoren (bijvoorbeeld de baan van een eventuele partner) werken mobiliteitsverlagend. 
Tabel 3.Ia laat zien dat Io procent van de Maastrichtse alumni die vijf jaar geleden zijn afgestudeerd meer dan vier banen hebben gehad. Medici wisselen het vaakst van baan. Van de medici heeft 72 procent vijf jaar na afstuderen meer dan 3 banen gehad, terwijl het gemiddelde $57 \%$ bedraagt. Juristen wisselen het minst vaak van baan. Na vijf jaar heeft 62 procent van de juristen minder dan drie banen gehad. Dit resultaat is vergelijkbaar met die van de vorige meting in 2004. Opvallend is dat alumni die tien jaar geleden de UM hebben verlaten gemiddeld genomen minder van baan zijn gewisseld dan alumni die vijf jaar geleden de UM hebben verlaten. Waarschijnlijk speelt hierbij mee dat alumni die tien jaar geleden de UM hebben verlaten onder minder gunstige omstandigheden de arbeidsmarkt hebben betreden. Dit is in lijn met het idee dat de vrijwillige mobiliteit geringer zal zijn wanneer er weinig vacatures zijn.

Tabel 3.1a

Aantal banen sinds afstuderen cohort 1998-1999 in procenten, 2005

$\begin{array}{lccccc} & \text { FdEWB } & \text { FdG } & \text { FdGW } & \text { FdR } & \text { Totaal } \\ \text { Minder dan 3 } & 42 & 28 & 45 & 62 & 43 \\ \text { 3-4 } & 48 & 56 & 47 & 33 & 47 \\ \text { Meer dan 4 } & 10 & 16 & 8 & 5 & 10 \\ \text { Bron: ROA } & & & & & \end{array}$

Tabel 3.1b

Aantal banen sinds afstuderen cohort 1993-1994 in procenten, 2005

$\begin{array}{lccccc} & \text { FdEWB } & \text { FdG } & \text { FdGW } & \text { FdR } & \text { Totaal } \\ \text { Minder dan } 3 & 56 & 68 & 68 & 72 & 66 \\ 3-4 & 4 & 26 & 30 & 24 & 31 \\ \text { Meer dan 4 } & 4 & 6 & 2 & 4 & 3\end{array}$

Bron: ROA

Vervolgens laten de tabellen $3.2 \mathrm{a}$ en $3.2 \mathrm{~b}$ het aantal werkgevers zien sinds het verlaten van de UM. Het aantal werkgevers is niet altijd gelijk aan het aantal banen. Mobiliteit binnen de bedrijven ligt hieraan ten grondslag. Alleen voor de alumni met detacheringcontracten of opleidingsplaatsen, zal het aantal werkgevers doorgaans lager zijn dan het aantal banen.

Tabel 3.2a

Aantal werkgevers sinds afstuderen cohort 1998-1999 in procenten, 2005

$\begin{array}{lccccc} & \text { FdEWB } & \text { FdG } & \text { FdGW } & \text { FdR } & \text { Totaal } \\ \text { Minder dan 3 } & 72 & 30 & 56 & 71 & 58 \\ 3-4 & 27 & 53 & 40 & 25 & 36 \\ \text { Meer dan 4 } & 1 & 17 & 4 & 4 & 6\end{array}$

Bron: ROA

Tabel 3.2b

Aantal werkgevers sinds afstuderen cohort 1993-1994 in procenten, 2005

$\begin{array}{lccccc} & \text { FdEWB } & \text { FdG } & \text { FdGW } & \text { FdR } & \text { Totaal } \\ \text { Minder dan 3 } & 83 & 65 & 83 & 79 & 79 \\ \text { 3-4 } & 18 & 28 & 16 & 18 & 19 \\ \text { Meer dan 4 } & 0 & 7 & 1 & 23 & 2\end{array}$

Bron: ROA 
Uit tabel 3.2 a blijkt dat 42 procent van de alumni vijf jaar na afstuderen meer dan 3 werkgevers heeft gehad. Ook hier blijkt dat afgestudeerde medici in hun loopbaan mobieler zijn dan afgestudeerden van andere faculteiten. Voor afgestudeerden van de UM loopt het aandeel alumni dat meer dan 3 werkgevers heeft gehad uiteen van 70 procent bij medici tot ongeveer 30 procent bij economen en juristen. Verder geldt dat 6 procent van de Maastrichtse alumni meer dan 4 werkgevers heeft gehad vijf jaar na afstuderen. Tabel 3.2b laat zien dat ongeveer een vijfde deel van de alumni die tien jaar geleden zijn afgestudeerd meer dan drie werkgevers hebben gehad. Ook hierbij geldt dat medici het vaakst zijn gewisseld van werkgever.

Tabel 3.3 gaat in op de geografische mobiliteit van Maastrichtse alumni. Vermeld is welk deel van de afgestudeerden werkzaam is in de provincie Limburg. Hieruit blijkt dat 27 procent van de alumni die vijf jaar en 3I procent van de alumni die tien jaar eerder de opleiding hebben verlaten, werkzaam zijn in Limburg. Daarbij zijn alumni van de FdR het vaakst werkzaam in Limburg; respectievelijk 4I procent en 52 procent. Verder valt op dat economen die tien jaar geleden de opleiding hebben verlaten veel vaker werken in Limburg dan economen die vijf jaar geleden de opleiding hebben verlaten. Hierbij speelt mee dat in de afgelopen jaren steeds meer studenten van buiten Limburg een opleiding volgen aan de UM. Studenten die niet afkomstig zijn uit Limburg zijn veel minder geneigd een baan te zoeken binnen de provincie Limburg.

Tabel 3.3

Aandeel van de alumni dat werkzaam is in Limburg, per afstudeercohort, 2005

$\begin{array}{cccccc} & \text { FdEWB } & \text { FdG } & \text { FdGW } & \text { FdR } & \text { Totaal } \\ 1998-1999 & 19 & 33 & 23 & 41 & 27 \\ 1993-1994 & 35 & 28 & 22 & 52 & 31 \\ \text { Bron: ROA } & & & & \end{array}$

Tabel 3.4a

Verschillen in loopbaanpatroon tussen mannen en vrouwen in procenten, cohort 1998-1999, 2005

\begin{tabular}{lcc} 
& Mannen & Vrouwen \\
Meer dan 3 banen & & 65 \\
FdEWB & 55 & 76 \\
FdG & 68 & 57 \\
FdGW & 45 & 36 \\
FdR & 41 & 58 \\
Totaal & 54 & \\
Meer dan 3 werkgevers & & 24 \\
FdEWB & 29 & 72 \\
FdG & 68 & 46 \\
FdGW & 35 & 29 \\
FdR & 27 & 44 \\
Totaal & 39 & 20 \\
Werkzaam in Limburg & & 20 \\
FdEWB & 20 & 22 \\
FdG & 35 & 43 \\
FdGW & 27 & 28 \\
FdR & 35 & \\
Totaal & 27 & \\
Bron: ROA & & \\
\hline
\end{tabular}

Bron: ROA 
Tot slot van deze paragraaf wordt stilgestaan bij de loopbaanverschillen van mannelijke en vrouwelijke alumni. Hiervoor zijn in de tabellen $3.4 \mathrm{a}$ en $3.4 \mathrm{~b}$ het aantal banen en werkgevers voor mannen en vrouwen weergegeven. Uit tabel 3.4a blijkt dat vrouwen na vijf jaar wat vaker van baan zijn gewisseld en meer werkgevers hebben gehad dan mannen. Het bovenstaande patroon zien we bij alumni die tien jaar eerder de UM hebben verlaten alléén terug bij de FdG. Van de vrouwelijke medici heeft tien jaar na afstuderen 39 procent meer dan 3 banen gehad, tegen 24 procent van de mannelijke medici. Daarnaast heeft 40 procent van de vrouwelijke medici meer dan 3 werkgevers gehad, tegen 32 procent van de mannelijk medici. Bij de FdGW zien we hier eerder het tegenovergestelde; tien jaar na afstuderen zijn mannelijke gezondheidswetenschappers vaker van baan gewisseld en hebben iets meer werkgevers gehad dan vrouwelijke gezondheidswetenschappers. Verder geldt voor alumni van de FdEWB en FdR die tien jaar eerder de opleiding hebben verlaten, dat mannen vaker werkzaam zijn in de provincie Limburg dan vrouwen.

\section{Tabel 3.4b}

Verschillen in loopbaanpatroon tussen mannen en vrouwen in percentages, cohort 1993-1994, 2005

$\begin{array}{lcc} & \text { Mannen } & \text { Vrouwen } \\ \text { Meer dan } 3 \text { banen } & & 43 \\ \text { FdEWB } & 44 & 39 \\ \text { FdG } & 24 & 27 \\ \text { FdGW } & 41 & 33 \\ \text { FdR } & 21 & 32 \\ \text { Totaal } & 36 & \\ \text { Meer dan } 3 \text { werkgevers } & & 23 \\ \text { FdEWB } & 14 & 40 \\ \text { FdG } & 32 & 16 \\ \text { FdGW } & 21 & 20 \\ \text { FdR } & 22 & 20 \\ \text { Totaal } & 21 & \\ \text { Werkzaam in Limburg } & & 26 \\ \text { FdEWB } & 42 & 32 \\ \text { FdG } & 21 & 21 \\ \text { FdGW } & 22 & 47 \\ \text { FdR } & 59 & 28 \\ \text { Totaal } & 35 & \end{array}$

\subsection{Individuele loopbaanpatronen}

In deze paragraaf wordt geprobeerd een beeld te geven van de individuele loopbaanpatronen van alumni. Hiertoe wordt met behulp van longitudinale gegevens de verschillende fasen in de loopbaan in hun onderlinge samenhang geanalyseerd. Centraal staat de impact van de start van de loopbaan op de rest van de carrière.

In de tabellen 3.5a en 3.5b wordt ingegaan op het aantal arbeidsuren. De vraag hier is of alumni die starten in een parttime baan ook in latere fasen van hun loopbaan 
parttime werken. Een parttime baan wil zeggen: een baan van 32 uur per week of minder. Aan de ene kant kan worden gesteld dat veel werknemers met een parttime baan tevreden zijn omdat dit vaak een persoonlijke keuze betreft, bijvoorbeeld om de werk- en gezinstaken te kunnen combineren. Aan de andere kant geldt dat de carrière voor werknemers met een parttime minder gunstig verloopt dan voor werknemers met een fulltime baan. Werkgevers zijn vooral geneigd te investeren in werknemers met een fulltime baan. Dit kan tot uiting komen in de beloning, trainingsmogelijkheden, promoties en dergelijke.

Tabel 3.5a

Arbeidsuren naar fase in de loopbaan in procenten, cohort 1998-1999, 2005

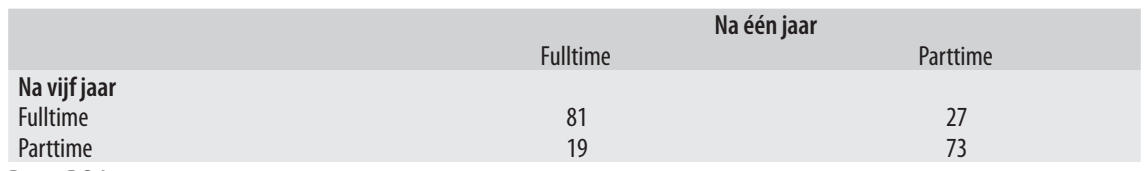

Bron: ROA

Tabel 3.5b

Arbeidsuren naar fase in de loopbaan in procenten, cohort 1993-1994, 2005

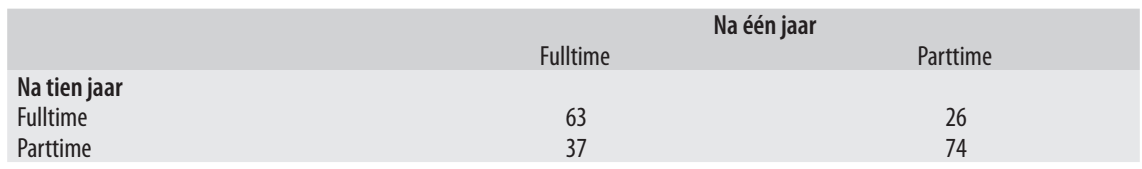

Bron: ROA

Uit tabel 3.5a wordt duidelijk dat vooral alumni die starten in een fulltime baan ook na vijf jaar nog steeds fulltime werken. Van de alumni die één jaar na het verlaten van de opleiding een fulltime baan hebben, heeft na vijf jaar 8I procent nog steeds een fulltime baan en 19 procent een parttime baan. Voor alumni die starten in een parttime baan is dit een geheel ander verhaal. Van de alumni die één jaar na afstuderen een parttime baan hebben, werkt na vijf jaar slechts 27 procent in een fulltime baan en 73 procent nog steeds in een parttime baan. Hetzelfde patroon zien we voor alumni die tien jaar geleden zijn afgestudeerd, hoewel de verschillen hier wat minder groot zijn. In totaal 63 procent van de alumni die starten in een fulltime baan, werkt tien jaar na afstuderen nog steeds fulltime. Van de alumni die starten in een parttime baan heeft na tien jaar slechts 26 procent een fulltime baan.

Persoonlijke omstandigheden, zoals het combineren van werk- met zorgtaken, doen mensen vaak kiezen voor een parttime baan. Aangezien nog steeds geldt dat vrouwen in het gezin doorgaans de zorgtaken op zich nemen, zullen vooral vrouwen in een parttime baan werkzaam zijn. Tabel 3.6 laat dit ook zien. In deze tabel zijn de in tabel 3.4b gepresenteerde cijfers uitgesplitst naar geslacht. Deze tabel laat zien dat van de mannen die na één jaar fulltime werkzaam zijn, 96 procent na tien jaar nog steeds fulltime werkt. Voor vrouwen geldt daarentegen dat slechts 38 procent van degenen die zijn gestart met een fulltime baan na tien jaar nog steeds werkzaam is in een fulltime baan. 
Tabel 3.6

Arbeidsuren naar fase in de loopbaan en geslacht in procenten, cohort 1993-1994, 2005

\begin{tabular}{llcc} 
& & Na één jaar & \\
\multirow{3}{*}{ Mannen } & Na tien jaar & Fulltime & Parttime \\
& Fulltime & & 46 \\
Vrouwen & Parttime & 96 & 54 \\
& Fulltime & 4 & 22 \\
& Parttime & 38 & 78
\end{tabular}

Bron: ROA

Geconcludeerd kan worden dat de loopbaanpatronen van mannen en vrouwen wat betreft het aantal arbeidsuren aanzienlijke verschillen vertonen. Vrouwen werken ook wanneer ze in een fulltime baan gestart zijn - na tien jaar vaak in een parttime baan. Dit patroon hebben we overigens ook in eerdere metingen gezien. Dit betekent dat nog steeds geldt dat vooral vrouwen kiezen voor een parttime baan, waarschijnlijk om de zorg voor kinderen te kunnen combineren met de baan.

Tabel 3.7a en tabel 3.7b geven een beeld van de baanzekerheid in de verschillende fasen van de loopbaan. Heeft een tijdelijke baan aan het begin van de loopbaan invloed op de baanzekerheid in een latere fase? Tabel 3.7a laat zien dat de start in een tijdelijke baan ook na vijf jaar nog duidelijk merkbaar is. Van de alumni met een vaste baan na één jaar, heeft na vijf jaar het overgrote deel nog steeds een vaste baan ( 94 procent). Van de alumni die na één jaar een tijdelijke aanstelling hadden, is het aandeel met een vaste baan duidelijk lager (65 procent). Hetzelfde patroon vinden we terug voor afgestudeerden die tien jaar eerder de opleiding hebben verlaten, maar hier zijn de verschillen in de baanzekerheid tussen degenen die wel en niet starten in een vaste baan relatief klein.

Tabel 3.7a

Aard dienstverband naar fase in de loopbaan in procenten, cohort 1998-1999, 2005

$\begin{array}{lcc} & \text { Na één jaar } & \text { Tijdelijke aanstelling } \\ \text { Na vijf jaar } & & \\ \text { Vaste aanstelling } & 94 & 65 \\ \text { Tijdelijke aanstelling } & 6 & 35 \\ \text { Bron: ROA } & & \end{array}$

Tabel 3.7b

Aard dienstverband naar fase in de loopbaan in procenten, cohort 1993-1994, 2005

$\begin{array}{lcc} & \text { Na één jaar } & \\ \text { Na tien jaar } & \text { Vaste aanstelling } & \text { Tijdelijke aanstelling } \\ \text { Vaste aanstelling } & 95 & 88 \\ \text { Tijdelijke aanstelling } & 5 & 12\end{array}$

Bron: ROA

De vraag is in hoeverre het hierboven geschetste beeld het gevolg is van institutionele factoren. $\mathrm{Na}$ het afstuderen hebben medici vaak een (per definitie tijdelijke) oplei- 
dingsplaats. Tabel 3.8 laat daarom de in tabel 3.7 a gepresenteerde cijfers zien, uitgesplitst naar faculteit. Zoals verwacht zijn medici voor een belangrijk deel verantwoordelijk voor het effect van een geringe baanzekerheid na één jaar op het al dan niet hebben van een vast contract na vijf jaar. Van de medici die na één jaar een tijdelijk contract hadden, heeft slechts 3I procent na vijf jaar een vaste baan. Van de medici die na één jaar een vaste aanstelling hadden, heeft 60 procent na vijf jaar nog steeds een vast dienstverband. Dit vinden we in zekere zin ook voor gezondheidswetenschappers. Van de gezondheidswetenschappers die zijn gestart in een tijdelijke aanstelling heeft 69 procent na vijf jaar een vaste aanstelling. Maar het overgrote deel van de gezondheidswetenschappers die zijn gestart in een vaste aanstelling heeft na vijf jaar nog steeds een vaste aanstelling. Bij de economen en juristen is het effect weliswaar aanwezig, maar duidelijk veel kleiner. Het overgrote deel van de economen en juristen die starten in een tijdelijke of vaste aanstelling heeft na vijf jaar een vaste baan.

Tabel 3.8

Aard dienstverband naar fase in de loopbaan en faculteit in procenten, cohort 1998-1999, 2005

\begin{tabular}{|c|c|c|c|}
\hline & & & \\
\hline & & Vaste aanstelling & Tijdelijke aanstelling \\
\hline & Na vijf jaar & & \\
\hline FdEWB & Vaste aanstelling & 96 & 87 \\
\hline & Tijdelijke aanstelling & 4 & 13 \\
\hline FdG & Vaste aanstelling & 60 & 31 \\
\hline & Tijdelijke aanstelling & 40 & 69 \\
\hline FdGW & Vaste aanstelling & 93 & 69 \\
\hline & Tijdelijke aanstelling & 7 & 31 \\
\hline $\mathrm{FdR}$ & Vaste aanstelling & 96 & 92 \\
\hline & Tijdelijke aanstelling & 4 & 8 \\
\hline
\end{tabular}

Bron: ROA

De tabellen 3.9a en 3.9b gaan in op de aansluiting tussen het niveau van de gevolgde opleiding en het niveau van de gevonden baan. Uit deze tabellen wordt duidelijk dat de start die alumni maken op de arbeidsmarkt een behoorlijke impact heeft op het verdere verloop van de carrière. Alumni die starten in een baan van WO-niveau zijn na vijf en tien jaar veel vaker werkzaam in een baan van WO-niveau dan alumni die starten in een baan van HBO-niveau of lager. Van de alumni die zijn begonnen in een baan van WO-niveau is om en nabij de 85 procent na vijf en tien jaar nog steeds werkzaam in een baan van WO-niveau. Van de alumni die starten in een baan onder WO-niveau heeft daarentegen minder dan de helft na vijf of tien jaar een baan van WO-niveau.

Tabel 3.9a

Aansluiting naar niveau naar fase in de loopbaan in procenten, cohort 1998-1999, 2005

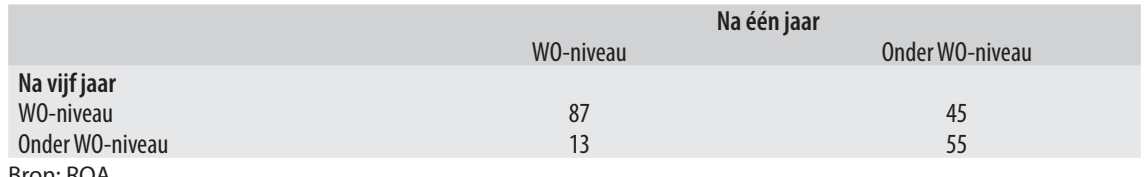


Tabel 3.9b

Aansluiting naar niveau naar fase in de loopbaan in procenten, cohort 1993-1994, 2005

$\begin{array}{lcc} & \text { Na één jaar } & \text { Onder W0-niveau } \\ \text { Na tien jaar } & \text { W0-niveau } & 48 \\ \text { W0-niveau } & 85 & 52\end{array}$

Bron: ROA

In tabel 3.IO zijn de cijfers uit tabel 3.9a nogmaals weergegeven maar dan uitgesplitst naar faculteit. Uit deze tabel blijkt dat het vooral voor economen van belang is om te starten in een baan van WO-niveau. Het overgrote deel van de economen dat is gestart in een baan van WO-niveau heeft na vijf jaar nog steeds een baan van WOniveau. Maar relatief veel economen die zijn gestart in een baan beneden WO-niveau zijn vijf jaar na afstuderen nog steeds werkzaam in een baan onder WO-niveau. Voor gezondheidswetenschappers geldt min of meer hetzelfde. Hier speelt echter mee dat een deel van de gezondheidswetenschappers een baan in de verpleging heeft, met een $\mathrm{HBO}$ achtergrond. Deze baan wordt vaak ook na het afronden van de academische studie gecontinueerd.

Tabel 3.10

Aansluiting naar niveau naar fase in de loopbaan en faculteit in procenten, cohort 1998-1999, 2005

\begin{tabular}{llcc} 
& & \multicolumn{2}{c}{ Na één jaar } \\
FdEWB & Na vijf jaar & W0-niveau & Onder W0-niveau \\
& W0-niveau & 92 & 47 \\
OnderW0-niveau & 8 & 53 \\
FdG & W0-niveau & 100 & - \\
& Onder W0-niveau & 0 & 39 \\
FdGW & W0-niveau & & 61 \\
& Onder W0-niveau & 73 & 67 \\
FdR & W0-niveau & 27 & 33 \\
& Onder W0-niveau & & \\
$-=$ komt niet voor & & 86 & \\
Bron: ROA & & &
\end{tabular}

Vervolgens wordt in de tabellen 3.IIa en 3.IIb ingegaan op de aansluiting tussen de gevolgde opleidingsrichting en baan. Ook hiervoor geldt dat de baan waarin alumni beginnen consequenties heeft voor het verdere verloop van de arbeidsloopbaan. In totaal is 86 procent van de alumni die start met een baan in het eigen beroependomein na vijf jaar nog steeds binnen het domein werkzaam. Ter vergelijking: 43 procent van de Maastrichtse alumni die zijn gestart in een baan buiten het eigen beroependomein heeft na vijf jaar een baan binnen het eigen domein. Een vergelijkbaar beeld komt naar voren uit tabel 3.rrb. Van de alumni die één jaar na afstuderen een baan heeft die aansluit bij de gevolgde opleidingsrichting heeft driekwart na tien jaar nog steeds een baan die aansluit bij de gevolgde opleidingsrichting. Voor degenen die starten in een 
baan buiten de gevolgde opleidingsrichting heeft na tien jaar slechts $53 \%$ een baan die hierbij aansluit.

Tabel $3.11 a$

Aansluiting naar richting naar fase in de loopbaan in procenten, cohort 1998-1999, 2005

$\begin{array}{lcc} & \text { Na één jaar } & \text { Andere richting } \\ \text { Na vijf jaar } & \text { Eigen richting } & \\ \text { Eigen richting } & 85 & 43 \\ \text { Andere richting } & 15 & 57\end{array}$

Bron: ROA

Tabel 3.11b

Aansluiting naar richting naar fase in de loopbaan in procenten, cohort 1993-1994, 2005

$\begin{array}{lcc} & \text { Na één jaar } & \\ \text { Na tien jaar } & \text { Eigen richting } & \text { Andere richting } \\ \text { Eigen richting } & 75 & 53 \\ \text { Andere richting } & 25 & 47\end{array}$

Bron: ROA

In tabel 3.I2 worden de cijfers uit tabel 3.IIa uitgesplitst naar faculteit. Deze tabel laat zien dat het hierboven gevonden resultaat voor alle faculteiten geldt, met uitzondering van de $\mathrm{FdG}$, waar iedereen binnen de eigen richting werkzaam is.

Tabel 3.12

Aansluiting naar richting naar fase in de loopbaan en faculteit in procenten, cohort 1993-1994, 2005

$\begin{array}{llcc} & & & \text { Na één jaar } \\ & \text { Na vijf jaar } & \text { Eigen richting } & \text { Andere richting } \\ \text { FdEWB } & \text { Eigen richting } & 76 & 41 \\ & \text { Andere richting } & 24 & 59 \\ \text { FdG } & \text { Eigen richting } & & 100 \\ & \text { Andere richting } & 100 & 0 \\ \text { FdGW } & \text { Eigen richting } & 0 & 42 \\ & \text { Andere richting } & & 58 \\ \text { FdR } & \text { Eigen richting } & 81 & 42 \\ & \text { Andere richting } & 19 & 58\end{array}$

Bron: ROA

Een aardige indicator om te laten zien welke groei de loopbaan van Maastrichtse alumni doormaken is de beloning. Het loon geeft immers een goede indicatie van de productiviteit die met de verworven kennis en vaardigheden wordt gegenereerd. Tabel 3.13 geeft een overzicht van de groei van het reële bruto uurloon naar cohort en faculteit. Dit is de absolute loongroei gecorrigeerd voor de inflatie. De inflatie bedroeg 26,0 procent gedurende de periode $1995-2005$ en I5 procent gedurende de periode 1999-2005. 
Tabel 3.13 laat zien dat voor het cohort 1998-1999 in de periode tussen één en vijf jaar na afstuderen de reële lonen met 56 procent zijn gestegen. Voor medici geldt dat de loongroei relatief vrij laag is, maar dit komt vooral omdat veel medici vijf jaar na afstuderen nog in een opleidingstraject zitten. Voor het cohort 1993-1994 bedroeg de loonstijging 127 procent. Dit is vrij opvallend gezien de economisch minder gunstige situatie waaronder dit cohort afstudeerde. Ook het cohort 1993-1994 heeft derhalve ten volle van de krapte op de arbeidsmarkt van de afgelopen jaren geprofiteerd. De lonen van medici zijn in deze tien jaar het meest gestegen, 207 procent. Met name gezondheidswetenschappers blijven hier met een reële loonstijging van 86 procent bij achter.

Tabel 3.13

Reële groei bruto uurloon in procenten naar cohort en faculteit

$\begin{array}{lccccc}\text { Cohort 1998-1999 } & \text { FdEWB } & \text { FdG } & \text { FdGW } & \text { FdR } & \text { Totaal } \\ \text { Na vijf jaar } & 70 & 53 & 43 & 63 & 56 \\ \begin{array}{l}\text { Cohort 1993-1994 } \\ \text { Na tien jaar } \\ \text { Bron: ROA }\end{array} & 154 & 207 & 86 & 108 & 127\end{array}$

In tabel 3.I4 wordt een overzicht gegeven van de groei van de beloning voor mannen en vrouwen. Hieruit blijkt dat de lonen voor mannen over het algemeen wat sneller zijn gestegen dan voor vrouwen. Voor het cohort 1998-1999 is de loonstijging voor mannen 9 procent groter dan voor vrouwen; voor de UM'ers die tien jaar geleden zijn afgestudeerd is dit verschil maar liefst 45 procent. Dit duidt er op dat vooral in de latere fase van de loopbaan de beloningsverschillen tussen mannen en vrouwen sterk uit elkaar gaan lopen. Enerzijds kan dit te maken hebben met het feit dat veel vrouwen na verloop van tijd parttime gaan werken. Werkgevers zijn vooral geneigd te investeren in werknemers met een fulltime baan. Dit komt vervolgens tot uiting in de kans op promotie, trainingsmogelijkheden en in de beloning. Anderzijds dient hierbij opgemerkt te worden dat het deels gaat om een studie-effect. Vrouwen kiezen relatief vaak voor de studie gezondheidswetenschappen. Tabel 3.13 heeft laten zien dat de loonstijging van gezondheidswetenschappers achter blijft bij de van alumni van andere faculteiten.

Tabel 3.14

Reële groei bruto uurloon in procenten naar cohort en geslacht

$\begin{array}{lccc}\text { Cohort 1998-1999 } & \text { Mannen } & \text { Vrouwen } & \text { Totaal } \\ \text { Na vijf jaar } & 61 & 52 & 56 \\ \begin{array}{l}\text { Cohort 1993-1994 } \\ \text { Na tien jaar }\end{array} & 155 & 110 & 127\end{array}$

Bron: ROA 


\subsection{Conclusie}

Dit belangrijkste conclusie van dit hoofdstuk is dat de start van de loopbaan grote gevolgen heeft voor de verdere loopbaan. Afgestudeerden van de UM die bij de start van hun carrière een goede arbeidsmarktpositie weten te verwerven, zoals een fulltime baan, vaste aanstelling en/of een baan die qua niveau en richting aansluit bij de gevolgde opleiding, hebben in de verdere loopbaan nog steeds een goede positie op de arbeidsmarkt. Dit geldt in veel mindere mate voor afgestudeerden die bij het begin van hun loopbaan een minder goede positie op de arbeidsmarkt weten te verwerven. Zo werkt 8I procent van de alumni die beginnen met een fulltime baan na vijf jaar nog steeds fulltime. Van de alumni die starten in een parttime baan werkt 'slechts' 27 procent vijf jaar na afstuderen fulltime. Een ongeveer vergelijkbaar patroon doet zich voor bij alumni die tien jaar eerder zijn afgestudeerd aan de UM.

Wat betreft de baanzekerheid blijkt dat het effect van een minder goede start gedurende de loopbaan langzaam wegebt. Naar voren is gekomen dat 94 procent van de alumni die starten in een vaste baan na vijf jaar nog steeds een vaste baan heeft, tegen 65 procent van de alumni die starten in een tijdelijke baan. Bij alumni die tien jaar eerder de opleiding hebben verlaten is dit verschil veel kleiner; 95 procent van de alumni die starten in een vaste baan en 88 procent van de alumni die starten in een tijdelijke baan heeft na tien jaar een vaste baan.

Starten in een baan van HBO-niveau of lager heeft grote gevolgen voor de verdere loopbaan. Meer dan de helft van deze alumni is na vijf en tien jaar nog steeds werkzaam in een baan van HBO-niveau of lager. Voor alumni die beginnen met een baan op WOniveau geldt daarentegen dat het merendeel in de verdere loopbaan nog steeds werkzaam is in een baan van WO-niveau. Het voorgaande geldt met name voor economen.

Bovendien blijkt dat vooral alumni die starten in een baan die aansluit bij de gevolgde opleidingsrichting in de verdere loopbaan nog steeds werkzaam zijn binnen de eigen opleidingsrichting. In totaal is 86 procent van de alumni die start met een baan in het eigen beroependomein na vijf jaar nog steeds binnen het domein werkzaam, tegen 43 procent van de alumni die zijn gestart in een baan buiten het eigen beroependomein. Een vrijwel vergelijkbaar beeld zien we voor alumni die tien jaar eerder de opleiding aan de UM hebben verlaten. Het voorgaande geldt voor alle faculteiten met uitzondering van alumni van de FdG.

De beloning geeft een goede indicatie van de groei die alumni in hun loopbaan doormaken. De reële lonen (loon gecorrigeerd voor inflatie) zijn voor cohort 1998-1999 in de periode tussen één en vijf jaar na afstuderen met 56 procent gestegen. Voor cohort I993-I994 is deze in de periode tussen één en tien jaar na afstuderen met maar liefst I27 procent gestegen. Vooral het loon van medici is na tien jaar flink toegenomen. 



\section{Vereiste competenties in de baan en verworven competenties in de opleiding}

\subsection{Inleiding}

De competenties die afgestudeerden hebben opgedaan in de opleiding geven een indicatie van de kwaliteit van de gevolgde opleiding in termen van de mate waarin studenten worden voorbereid op de beroepspraktijk. Het is dan ook niet vreemd dat in de afgelopen jaren sprake is van een toenemende belangstelling voor competenties als opbrengsten of eindtermen van het gevolgde onderwijs. Ook in het kader van de invoering van de BaMa structuur in het hoger onderwijs en de daarbij behorende discussie over accreditatie- en toetsingskaders van HBO- en WO-opleidingen. De vraag die daarbij naar voren komt is in hoeverre afgestudeerden van de UM in voldoende mate worden voorzien van competenties die nodig zijn voor de arbeidsmarkt? In dit hoofdstuk wordt dit nader bekeken door verschillen tussen het eigen niveau van competenties en het vereist niveau van competenties op de arbeidsmarkt in beeld te brengen. Dit wordt gedaan voor afgestudeerden van de verschillende faculteiten van de UM die één, vijf en tien jaar geleden zijn afgestudeerd. Hierbij zijn de cijfers van de meest recente metingen 2004 en 2005 samengenomen. Cijfers voor de FdCW zijn niet opgenomen in dit hoofdstuk vanwege het kleine aantal respondenten van deze faculteit in onze onderzoekspopulatie.

Aan de afgestudeerden is een lijst van 23 competenties voorgelegd die in het werk van belang kunnen zijn. Deze competenties lopen uiteen van vakspecifiek, zoals kennis van het eigen vakgebied, tot generiek, zoals productief met anderen samenwerken en nieuwe dingen leren. Aan de afgestudeerden is gevraagd voor iedere competentie het niveau aan te geven dat vereist is in de huidige functie (op een vijfpuntschaal lopend van 'matig' tot 'uitmuntend'). Daarnaast is gevraagd naar het eigen niveau van de competenties (ook op een vijfpuntschaal lopend van 'matig' tot 'uitmuntend'). Vervolgens kan voor iedere afgestudeerde worden bepaald of het vereist niveau van een competentie hoger is dan het eigen niveau. Aan de hand hiervan hebben we voor elke competentie het aandeel afgestudeerden bepaald dat een tekort ervaart aan de betreffende competentie in de huidige baan. ${ }^{4}$ Omdat afgestudeerden primair worden

4. De overige afgestudeerden ervaren geen tekort omdat het vereist niveau van de competenties in de baan gelijk is aan het eigen niveau (gelijk) danwel omdat het eigen niveau hoger is dan het vereist niveau van de competenties (surplus). 
voorbereid voor banen van WO-niveau in het eigen beroependomein, hebben we in dit hoofdstuk alléén afgestudeerden opgenomen met een baan op WO-niveau die aansluit bij eigen of verwante opleidingsrichting. Hoofdstuk 2 heeft laten zien dat het merendeel van de afgestudeerden die één, vijf en tien jaar geleden zijn afgestudeerd een baan heeft op WO-niveau die aansluit bij eigen of verwante opleidingsrichting.

In dit hoofdstuk worden eerst de resultaten gepresenteerd voor de gehele UM. Daarna volgen de resultaten per faculteit.

\subsection{Verschillen tussen vereist en eigen niveau van competenties}

Tabel 4.I vermeldt voor de 23 competenties het aandeel afgestudeerden waarvan het vereist niveau van de competentie in de baan hoger is dan het eigen niveau (tekort). Hieruit blijkt dat alumni doorgaans het vaakst tekorten ervaren in de competentie vermogen om aan anderen duidelijk te maken wat u bedoelt. In totaal 35 procent van de Maastrichtse alumni die één jaar geleden is afgestudeerd, geeft aan dat in de baan het vereist niveau van deze competentie hoger is dan het eigen niveau. Onder afgestudeerden die vijf en tien jaar geleden zijn afgestudeerd is dit percentage ongeveer vergelijkbaar, respectievelijk 39 procent en 34 procent.

Daarnaast is opvallend dat relatief veel recent afgestudeerden aangegeven dat ze een tekort ervaren in de competenties kennis van het eigen vakgebied en vakkennis toepassen in de praktijk. Ongeveer 30 procent van de recent afgestudeerden zegt hier dat het eigen niveau van deze competenties tekortschiet in vergelijking met het vereist niveau in de baan. Overigens zal in het vervolg van dit hoofdstuk duidelijk worden dat dit aandeel sterk uiteenloopt voor afgestudeerden van de verschillende faculteiten van de UM. Ook voor de competenties problemen en kansen signaleren, hoofd- van bijzaken onderscheiden, knopen doorhakken en nieuwe ideeën en oplossingen bedenken geldt dat relatief veel recent afgestudeerden aangeven dat het vereist niveau hoger is dan het eigen niveau (aandeel 30 procent of meer). Wel blijkt dat in de latere stadia van de loopbaan bij de competenties hoofd-van bijzaken onderscheiden, vermogen om knopen door te hakken en vermogen om nieuwe ideeën en oplossingen te bedenken deze tekorten verminderen.

Voor een aantal competenties geldt dat relatief weinig startende alumni tekorten ervaren in de huidige baan. Dit zijn de competenties ICT gebruiken, in buitenlandse talen communiceren, nek uitsteken en begrip tonen voor andere standpunten (aandeel is kleiner dan 20 procent). Hetzelfde geldt voor alumni die vijf en tien jaar geleden zijn afgestudeerd, met uitzondering van de competentie vermogen om ICT te gebruiken. Alumni die vijf en tien jaar geleden zijn afgestudeerd ervaren vaker dan alumni die één jaar geleden zijn afgestudeerd een tekort aan de competentie vermogen om ICT gebruiken. Waarschijnlijk komt dit omdat jongere werknemers zich over het algemeen sneller aanpassen aan technologische veranderingen dan oudere werknemers. 
Verder is interessant dat alumni in de latere stadia van de loopbaan steeds minder tekorten ervaren in de competentie zelfstandig werkzaamheden uitvoeren. Tabel 2.9 heeft laten zien dat deze competentie zeer belangrijk is bij het uitvoeren van de werkzaamheden. Tabel 4.I toont aan dat afgestudeerden in de latere stadia van de loopbaan beter weten te voldoen aan de eisen van de baan als het gaat om het zelfstandig uitvoeren van werkzaamheden. Het tegenovergestelde zien we bij de competentie capaciteiten van anderen aanspreken. Hier zien we dat met name alumni die tien jaar geleden zijn afgestudeerd in mindere mate voldoen aan de eisen van de baan. Dit heeft waarschijnlijk te maken met het feit dat alumni in de latere fasen van de loopbaan vaker in leidinggevende functies terecht komen, waardoor deze competentie steeds meer wordt vereist in de baan.

\section{Tabel 4.1}

Tekorten aan competenties van afgestudeerden ${ }^{a}$, in procenten per afstudeercohort, 2004-2005

\begin{tabular}{|c|c|c|c|}
\hline & $\begin{array}{c}\text { Eén jaar na afstuderen } \\
\%\end{array}$ & $\begin{array}{c}\text { Vijf jaar na afstuderen } \\
\%\end{array}$ & $\begin{array}{c}\text { Tien jaar na afstuderen } \\
\%\end{array}$ \\
\hline \multicolumn{4}{|l|}{ Kennis van: } \\
\hline het eigen vakgebied & 31 & 38 & 31 \\
\hline andere vakgebieden & 27 & 23 & 18 \\
\hline \multicolumn{4}{|l|}{ Vermogen om: } \\
\hline vakkennis in de praktijk toe te passen & 30 & 32 & 22 \\
\hline ICT te gebruiken & 16 & 19 & 22 \\
\hline in buitenlandse talen te communiceren & 13 & 12 & 13 \\
\hline informatie te vergaren & 23 & 22 & 20 \\
\hline problemen en kansen te signaleren & 30 & 30 & 30 \\
\hline verbanden leggen tussen verschillende zaken & 27 & 29 & 21 \\
\hline hoofdzaken van bijzaken te onderscheiden & 33 & 32 & 25 \\
\hline logisch te redeneren & 23 & 20 & 18 \\
\hline conform budget, planning, richtlijnen werken & 28 & 27 & 28 \\
\hline onder druk goed te functioneren & 29 & 29 & 24 \\
\hline knopen door te hakken & 33 & 31 & 24 \\
\hline nieuwe ideeën en oplossingen te bedenken & 33 & 27 & 26 \\
\hline nieuwe dingen te leren & 18 & 20 & 15 \\
\hline aan anderen duidelijk te maken wat u bedoelt & 35 & 39 & 34 \\
\hline productief met anderen samen te werken & 16 & 18 & 18 \\
\hline capaciteiten van anderen aan te spreken & 25 & 24 & 30 \\
\hline zelfstandig de werkzaamheden uit te voeren & 23 & 18 & 16 \\
\hline \multicolumn{4}{|l|}{ Bereidheid om: } \\
\hline nek uit te steken & 17 & 17 & 18 \\
\hline (eigen) ideeën ter discussie te stellen & 26 & 23 & 20 \\
\hline op te komen voor eigen standpunt & 26 & 27 & 21 \\
\hline begrip te tonen voor andere standpunten & 14 & 18 & 19 \\
\hline
\end{tabular}

\subsection{Tekorten aan competenties naar faculteit}

Tot nog toe hebben we een algemeen beeld gegeven van de tekorten aan competenties die Maastrichts alumni ervaren in de huidige baan. In deze paragraaf worden deze 
tekorten per faculteit bekeken. Ook hier geldt dat ervoor is gekozen alléén afgestudeerden met een baan van WO-niveau die aansluit bij de gevolgde opleidingsrichting mee te nemen in de analyse.

\section{Economie}

Tabel 4.2 laat tekorten aan competenties zien in de huidige baan voor economen. Deze tabel komt deels overeen met het algehele beeld voor de UM in tabel 4.I, maar wijkt op een aantal belangrijke punten hiervan af. Allereerst geldt ook voor afgestudeerden van de faculteit economie dat ze vaak een tekort ervaren aan de competentie vermogen om aan anderen duidelijk te maken wat je bedoelt. Waar economen verschillen van andere Maastrichtse alumni is dat dit percentage duidelijk toeneemt naarmate economen verder zijn in hun loopbaan. Bijna de helft van de economen die tien jaar geleden is afgestudeerd zegt dat het eigen niveau van de competentie vermogen om aan anderen duidelijk te maken wat je bedoelt onvoldoende is ten opzichte van het vereist niveau.

Tabel 4.2

Tekorten aan competenties van afgestudeerden economie ${ }^{a}$, in procenten per afstudeercohort, 2004-2005

\begin{tabular}{|c|c|c|c|}
\hline & $\begin{array}{c}\text { Eén jaar na } \\
\text { afstuderen } \\
\%\end{array}$ & $\begin{array}{c}\text { Vijf jaar na } \\
\text { afstuderen } \\
\%\end{array}$ & $\begin{array}{c}\text { Tien jaar na } \\
\text { afstuderen } \\
\%\end{array}$ \\
\hline \multicolumn{4}{|l|}{ Kennis van: } \\
\hline het eigen vakgebied & 22 & 33 & 27 \\
\hline andere vakgebieden & 35 & 29 & 21 \\
\hline \multicolumn{4}{|l|}{ Vermogen om: } \\
\hline vakkennis in de praktijk toe te passen & 23 & 24 & 13 \\
\hline ICT te gebruiken & 15 & 18 & 16 \\
\hline in buitenlandse talen te communiceren & 13 & 11 & 17 \\
\hline informatie te vergaren & 19 & 25 & 20 \\
\hline problemen en kansen te signaleren & 31 & 30 & 31 \\
\hline verbanden leggen tussen verschillende zaken & 19 & 25 & 20 \\
\hline hoofdzaken van bijzaken te onderscheiden & 27 & 29 & 24 \\
\hline logisch te redeneren & 20 & 14 & 15 \\
\hline conform budget, planning, richtlijnen werken & 31 & 27 & 28 \\
\hline onder druk goed te functioneren & 26 & 21 & 18 \\
\hline knopen door te hakken & 24 & 26 & 24 \\
\hline nieuwe ideeën en oplossingen te bedenken & 31 & 20 & 28 \\
\hline nieuwe dingen te leren & 16 & 15 & 12 \\
\hline aan anderen duidelijk te maken wat u bedoelt & 33 & 40 & 48 \\
\hline productief met anderen samen te werken & 20 & 26 & 23 \\
\hline capaciteiten van anderen aan te spreken & 26 & 24 & 42 \\
\hline zelfstandig de werkzaamheden uit te voeren & 17 & 17 & 15 \\
\hline \multicolumn{4}{|l|}{ Bereidheid om: } \\
\hline nek uit te steken & 15 & 12 & 10 \\
\hline (eigen) ideeën ter discussie te stellen & 22 & 20 & 16 \\
\hline op te komen voor eigen standpunt & 21 & 25 & 18 \\
\hline begrip te tonen voor andere standpunten & 16 & 22 & 16 \\
\hline
\end{tabular}


Waarschijnlijk speelt hierbij dat vooral veel economen in de verdere loopbaan in een leidinggevende functie terecht komen (zie tabel 2.8). Blijkbaar worden afgestudeerden economie in hun functie in steeds grotere mate aangesproken op hun leidinggevende capaciteiten, maar weten daar niet in dié mate aan te voldoen. Een andere indicatie hiervoor is dat ook het aandeel economen dat zegt een tekort te ervaren aan de competentie vermogen om capaciteiten van anderen aan te spreken behoorlijk toeneemt naarmate de loopbaan verder is gevorderd.

Opvallend is verder dat afgestudeerde economen minder vaak dan de gemiddelde afgestudeerde van de UM aangeven dat ze een tekort ervaren in de competenties kennis van het eigen vakgebied en vakkennis in de praktijk toepassen. Dit wijst er op dat de opleidingen economie aan de UM redelijk goed in staat zijn de afgestudeerden te voorzien van kennis van het eigen vakgebied en het vermogen om deze kennis toe te passen in de huidige baan. Daartegenover staat dat afgestudeerde economen vaker dan de gemiddelde Maastrichtse afgestudeerde een tekort ervaren aan de competentie productief met anderen samenwerken.

\section{Geneeskunde}

In tabel 4.3 zijn de tekorten aan competenties in de huidige baan van afgestudeerden geneeskunde weergegeven. Opvallend gezien het beroepsgerichte karakter van de opleiding geneeskunde is dat hieruit naar voren komt dat afgestudeerden geneeskunde vaker dan de gemiddelde Maastrichtse alumni tekorten ondervinden in de competentie kennis van het eigen vakgebied. Bovendien neemt dit tekort gedurende de verdere loopbaan van medici niet af. In totaal 47 procent van de medici die vijf jaar geleden is afgestudeerd en 39 procent van de medici die tien jaar geleden is afgestudeerd zegt dat het vereist niveau van de competentie kennis van het eigen vakgebied hoger is dan het eigen niveau. Daarnaast geldt dat vooral medici die vijf jaar eerder zijn afgestudeerd vaak aangeven een tekort te ervaren aan de competentie vakkennis toepassen in de praktijk (45 procent).

Bovendien ondervinden afgestudeerde medici die vijf en tien jaar geleden zijn afgestudeerd vaker een tekort aan de competenties vermogen om nieuwe dingen te leren, onder druk goed te functioneren en bereidheid om uw nek uit te steken (verschil met de gemiddelde afgestudeerde van de UM meer dan 5 procent). Voor recent afgestudeerde medici en afgestudeerde medici die vijf jaar eerder de UM hebben verlaten geldt dat het eigen niveau van de competentie vermogen om knopen door te hakken relatief vaak onvoldoende is in vergelijking met het vereist niveau in de baan. Verder wordt duidelijk dat relatief veel medici in de latere stadia van de loopbaan steeds meer problemen ondervinden met het gebruik van ICT. Tot slot valt op dat relatief weinig afgestudeerden geneeskunde aangegeven dat ze een tekort hebben aan de competentie in buitenlandse talen communiceren. 
Tabel 4.3

Tekorten aan competenties van afgestudeerden geneeskunde ${ }^{\mathrm{a}}$, in procenten per afstudeercohort, 2004-2005

\begin{tabular}{|c|c|c|c|}
\hline & $\begin{array}{c}\text { Eén jaar } \\
\text { na afstuderen } \\
\%\end{array}$ & $\begin{array}{c}\text { Vijf jaar na } \\
\text { afstuderen } \\
\%\end{array}$ & $\begin{array}{c}\text { Tien jaar na } \\
\text { afstuderen } \\
\%\end{array}$ \\
\hline \multicolumn{4}{|l|}{ Kennis van: } \\
\hline het eigen vakgebied & 38 & 47 & 39 \\
\hline andere vakgebieden & 22 & 29 & 18 \\
\hline \multicolumn{4}{|l|}{ Vermogen om: } \\
\hline vakkennis in de praktijk toe te passen & 28 & 45 & 27 \\
\hline ICT te gebruiken & 17 & 23 & 25 \\
\hline in buitenlandse talen te communiceren & 5 & 11 & 8 \\
\hline informatie te vergaren & 17 & 23 & 20 \\
\hline problemen en kansen te signaleren & 22 & 32 & 27 \\
\hline verbanden leggen tussen verschillende zaken & 28 & 35 & 22 \\
\hline hoofdzaken van bijzaken te onderscheiden & 37 & 35 & 28 \\
\hline logisch te redeneren & 27 & 21 & 23 \\
\hline conform budget, planning, richtlijnen werken & 21 & 29 & 34 \\
\hline onder druk goed te functioneren & 33 & 36 & 32 \\
\hline knopen door te hakken & 39 & 40 & 24 \\
\hline nieuwe ideeën en oplossingen te bedenken & 25 & 28 & 24 \\
\hline nieuwe dingen te leren & 18 & 27 & 22 \\
\hline aan anderen duidelijk te maken wat $u$ bedoelt & 31 & 41 & 31 \\
\hline productief met anderen samen te werken & 13 & 21 & 20 \\
\hline capaciteiten van anderen aan te spreken & 24 & 26 & 33 \\
\hline zelfstandig de werkzaamheden uit te voeren & 23 & 24 & 17 \\
\hline \multicolumn{4}{|l|}{ Bereidheid om: } \\
\hline nek uit te steken & 20 & 23 & 25 \\
\hline (eigen) ideeën ter discussie te stellen & 23 & 27 & 25 \\
\hline op te komen voor eigen standpunt & 24 & 29 & 18 \\
\hline begrip te tonen voor andere standpunten & 11 & 21 & 18 \\
\hline
\end{tabular}

\section{Gezondheidswetenschappen}

Tabel 4.4 vermeldt de tekorten aan competenties in de huidige baan van afgestudeerden van de faculteit gezondheidswetenschappen. Afgestudeerden gezondheidswetenschappen ondervinden in de huidige baan doorgaans minder tekorten aan de competenties kennis van het eigen vakgebied en vakkennis toepassen in de praktijk dan de gemiddelde Maastrichtse alumni. Daarnaast geldt dat afgestudeerden gezondheidswetenschappen die vijf en tien jaar geleden zijn afgestudeerd minder vaak dan de gemiddelde afgestudeerde van de UM aangeven dat ze een tekort ervaren aan de competenties vermogen om nieuwe dingen te leren. Verder blijkt dat ook gezondheidswetenschappers in de latere stadia van de loopbaan tekorten ervaren in het vermogen om ICT te gebruiken. 
Tabel 4.4

Tekorten aan competenties van afgestudeerden gezondheidswetenschappen ${ }^{\text {a }}$, in procenten per afstudeercohort, 2004-2005

\begin{tabular}{|c|c|c|c|}
\hline & $\begin{array}{c}\text { Eén jaar } \\
\text { na afstuderen } \\
\%\end{array}$ & $\begin{array}{c}\text { Vijf jaar na } \\
\text { afstuderen } \\
\%\end{array}$ & $\begin{array}{c}\text { Tien jaar na } \\
\text { afstuderen } \\
\%\end{array}$ \\
\hline \multicolumn{4}{|l|}{ Kennis van: } \\
\hline het eigen vakgebied & 28 & 26 & 27 \\
\hline andere vakgebieden & 26 & 20 & 19 \\
\hline \multicolumn{4}{|l|}{ Vermogen om: } \\
\hline vakkennis in de praktijk toe te passen & 28 & 24 & 22 \\
\hline ICT te gebruiken & 17 & 19 & 27 \\
\hline in buitenlandse talen te communiceren & 17 & 16 & 17 \\
\hline informatie te vergaren & 23 & 21 & 21 \\
\hline problemen en kansen te signaleren & 30 & 23 & 32 \\
\hline verbanden leggen tussen verschillende zaken & 26 & 26 & 18 \\
\hline hoofdzaken van bijzaken te onderscheiden & 30 & 32 & 23 \\
\hline logisch te redeneren & 18 & 21 & 16 \\
\hline conform budget, planning, richtlijnen werken & 29 & 30 & 25 \\
\hline onder druk goed te functioneren & 26 & 28 & 19 \\
\hline knopen door te hakken & 31 & 29 & 23 \\
\hline nieuwe ideeën en oplossingen te bedenken & 34 & 28 & 32 \\
\hline nieuwe dingen te leren & 16 & 14 & 10 \\
\hline aan anderen duidelijk te maken wat u bedoelt & 39 & 38 & 32 \\
\hline productief met anderen samen te werken & 16 & 12 & 18 \\
\hline capaciteiten van anderen aan te spreken & 27 & 25 & 29 \\
\hline zelfstandig de werkzaamheden uit te voeren & 26 & 15 & 15 \\
\hline \multicolumn{4}{|l|}{ Bereidheid om: } \\
\hline nek uit te steken & 14 & 16 & 16 \\
\hline (eigen) ideeën ter discussie te stellen & 29 & 25 & 21 \\
\hline op te komen voor eigen standpunt & 27 & 30 & 25 \\
\hline begrip te tonen voor andere standpunten & 12 & 12 & 21 \\
\hline
\end{tabular}

\section{Rechten}

In tabel 4.5 zijn voor afgestudeerde juristen de tekorten aan competenties weergegeven. Wat meteen opvalt aan tabel 4.5 is dat juristen die één jaar geleden zijn afgestudeerd in de huidige baan veel vaker tekorten ervaren aan competenties dan andere recent afgestudeerden van de UM. Dit komt vooral tot uitdrukking bij de competenties vakkennis, vakkennis toepassen in de praktijk, vermogen om informatie te vergaren en knopen door te hakken (verschil met de gemiddelde UM'er tenminste io procent). Overigens vinden we bovenstaande genoemde verschillen niet terug onder afgestudeerden die vijf en tien jaar geleden zijn afgestudeerd. Integendeel onder afgestudeerden die tien jaar geleden zijn afgestudeerd zien we juist dat juristen minder vaak dan andere afgestudeerde UM'ers tekorten ervaren aan competenties kennis van het eigen vakgebied. Hier staat tegenover dat juristen die vijf en tien jaar geleden zijn afgestudeerd vaker dan afgestudeerden van andere faculteiten tekorten ervaren in de competenties productief met anderen samenwerken, capaciteiten van anderen aanspreken en eigen ideeën ter discussie stellen. 
Tabel 4.5

Tekorten aan competenties van afgestudeerden rechten ${ }^{\mathrm{a}}$, in procenten per afstudeercohort, 20042005

\begin{tabular}{|c|c|c|c|}
\hline & $\begin{array}{c}\text { Eén jaar na } \\
\text { afstuderen } \\
\%\end{array}$ & $\begin{array}{c}\text { Vijf jaar na } \\
\text { afstuderen } \\
\%\end{array}$ & $\begin{array}{c}\text { Tien jaar na } \\
\text { afstuderen } \\
\%\end{array}$ \\
\hline \multicolumn{4}{|l|}{ Kennis van: } \\
\hline het eigen vakgebied & 41 & 42 & 24 \\
\hline andere vakgebieden & 27 & 22 & 12 \\
\hline \multicolumn{4}{|l|}{ Vermogen om: } \\
\hline vakkennis in de praktijk toe te passen & 41 & 31 & 21 \\
\hline ICT te gebruiken & 13 & 14 & 14 \\
\hline in buitenlandse talen te communiceren & 16 & 13 & 9 \\
\hline informatie te vergaren & 33 & 20 & 18 \\
\hline problemen en kansen te signaleren & 34 & 34 & 29 \\
\hline verbanden leggen tussen verschillende zaken & 36 & 27 & 24 \\
\hline hoofdzaken van bijzaken te onderscheiden & 37 & 27 & 23 \\
\hline logisch te redeneren & 30 & 22 & 17 \\
\hline conform budget, planning, richtlijnen werken & 28 & 20 & 23 \\
\hline onder druk goed te functioneren & 35 & 30 & 24 \\
\hline knopen door te hakken & 47 & 25 & 24 \\
\hline nieuwe ideeën en oplossingen te bedenken & 40 & 31 & 19 \\
\hline nieuwe dingen te leren & 23 & 24 & 10 \\
\hline aan anderen duidelijk te maken wat u bedoelt & 40 & 34 & 33 \\
\hline productief met anderen samen te werken & 16 & 9 & 12 \\
\hline capaciteiten van anderen aan te spreken & 19 & 16 & 18 \\
\hline zelfstandig de werkzaamheden uit te voeren & 24 & 11 & 15 \\
\hline \multicolumn{4}{|l|}{ Bereidheid om: } \\
\hline nek uit te steken & 21 & 14 & 18 \\
\hline (eigen) ideeën ter discussie te stellen & 28 & 13 & 12 \\
\hline op te komen voor eigen standpunt & 31 & 21 & 22 \\
\hline begrip te tonen voor andere standpunten & 18 & 16 & 17 \\
\hline
\end{tabular}

\section{Psychologie}

Tabel 4.6 laat voor afgestudeerden psychologie de tekorten aan competenties zien. Zoals eerder is aangegeven is alléén informatie beschikbaar over psychologen één jaar na afstuderen omdat deze faculteit nog relatief jong is. Naar voren komt dat recent afgestudeerden psychologen vaker tekorten ervaren in de competenties kennis van het eigen vakgebied en vakkennis toepassen in de praktijk dan de gemiddelde Maastrichtse alumni. Hetzelfde kan worden gezegd voor de competenties vermogen om hoofd- van bijzaken te onderscheiden en nieuwe ideeën en oplossingen bedenken. Wat betreft de competenties onder druk goed functioneren en kennis van andere vakgebieden ondervinden psychologen minder vaak tekorten in de huidige functie dan de gemiddelde UM'er. 
Tabel 4.6

Tekorten aan competenties van afgestudeerden psychologie ${ }^{a}$, in procenten, 2004-2005

$\begin{array}{lr}\text { Kennis van: } & \text { Eén jaar na afst } \\ \text { het eigen vakgebied } & 36 \\ \text { andere vakgebieden } & 21 \\ & \\ \text { Vermogen om: } & 36 \\ \text { vakkennis in de praktijk toe te passen } & 13 \\ \text { ICT te gebruiken } & 11 \\ \text { in buitenlandse talen te communiceren } & 24 \\ \text { informatie te vergaren } & 33 \\ \text { problemen en kansen te signaleren } & 29 \\ \text { verbanden leggen tussen verschillende zaken } & 38 \\ \text { hoofdzaken van bijzaken te onderscheiden } & 22 \\ \text { logisch te redeneren } & 32 \\ \text { conform budget, planning, richtlijnen werken } & 22 \\ \text { onder druk goed te functioneren } & 31 \\ \text { knopen door te hakken } & 40 \\ \text { nieuwe ideeën en oplossingen te bedenken } & 22 \\ \text { nieuwe dingen te leren } & 31 \\ \text { aan anderen duidelijk te maken wat u bedoelt } & 15 \\ \text { productief met anderen samen te werken } & 29 \\ \text { capaciteiten van anderen aan te spreken } & 25 \\ \text { zelfstandig de werkzaamheden uit te voeren } & \\ \text { Bereidheid om: } & \\ \text { nek uit te steken } & 18 \\ \text { (eigen) ideeën ter discussie te stellen } & 27 \\ \text { op te komen voor eigen standpunt } & 27 \\ \text { begrip te tonen voor andere standpunten } & 14\end{array}$

Eén jaar na afstuderen

a afgestudeerden met een baan van WO-niveau, die aansluit bij de gevolgde opleidingrichting Bron: ROA

\subsection{Conclusie}

In dit hoofdstuk is bekeken in hoeverre Maastrichtse alumni tekorten ervaren in de huidige baan. Dit is gedaan voor 23 verschillende competenties. Voor elke competentie is het vereist niveau in de baan vergeleken met het eigen niveau van de afgestudeerde. Allereerst is naar voren gekomen dat alumni het vaakst aangeven dat ze een tekort ervaren in de competentie aan anderen duidelijk maken wat u bedoelt. Dit geldt zowel voor recent afgestudeerden als voor afgestudeerden van de UM die zich al langer op de arbeidsmarkt bevinden. Met name economen die vijf en tien jaar eerder de UM hebben verlaten, ondervinden tekorten aan de competentie vermogen om aan anderen duidelijk maken wat u bedoelt. Hetzelfde zien we voor economen bij de competentie capaciteiten aanspreken. Waarschijnlijk komt dit omdat veel van deze economen een leidinggevende functie hebben.

Voor het merendeel van de overige competenties geldt echter dat alumni na verloop van tijd meegroeien met hun baan. Zo ervaren recent afgestudeerden relatief vaak tekorten in de competenties hoofd-van bijzaken onderscheiden, knopen doorhakken 
en nieuwe ideeën en oplossingen bedenken. Onder afgestudeerden die zich in de latere stadia van de loopbaan bevinden zijn deze tekorten echter afgenomen. Daarnaast blijkt dat recent afgestudeerden juristen in hun baan veel vaker tekorten ervaren in competenties dan andere Maastrichtse alumni. Maar dit geldt alléén voor recent afgestudeerde juristen. Voor juristen die vijf en tien jaar geleden zijn afgestudeerd zijn de tekorten aan competenties niet groter dan voor de gemiddelde UM'er. Ook hier blijkt dus dat de alumni meegroeien met hun baan.

Er zijn echter enkele uitzonderingen waarbij dit niet geldt. Meest opvallend in dit verband is dat relatief veel medici aangeven dat ze een tekort ervaren in de competentie kennis van het eigen vakgebied. Dit tekort blijft bij medici in de latere stadia van de loopbaan bestaan. Verder ervaren Maastrichtse alumni in de latere stadia van hun loopbaan steeds meer tekorten aan de competentie vermogen om ICT te gebruiken. Dit geldt met name voor medici en gezondheidswetenschappers. Waarschijnlijk speelt hier mee dat jongere werknemers zich over het algemeen sneller aanpassen aan technologische veranderingen dan oudere werknemers. 


\section{Zijn de competenties die in het werken worden vereist in de opleiding opgedaan?}

In het vorige hoofdstuk is een algemeen beeld gegeven van tekorten aan competenties in de huidige functie van afgestudeerden. In dit hoofdstuk wordt nagegaan in hoeverre volgens afgestudeerden competenties die op een hoog niveau worden vereist in de functie vooral binnen de WO-opleiding hebben opgedaan. Ook wordt bekeken op welke manier de leeromgeving (onderwijsmethode en werkvormen) bij kan dragen aan het verwerven van competenties die vaak op een hoog niveau worden vereist in het werk.

Om dit te onderzoeken hebben we voor elke faculteit de vijf meest voorkomende beroepen genomen waarin afgestudeerden anderhalf jaar na afstuderen werkzaam zijn. Voor deze afgestudeerden zijn vijf competenties bepaald die in het werk het vaakst op een hoog niveau worden vereist (uit een lijst van 23 competenties, zie Hoofdstuk 4). Vervolgens wordt bekeken in hoeverre afgestudeerden vinden dat deze vijf competenties vooral binnen de WO-opleiding zijn geleerd. Op deze manier wordt duidelijk of competenties die voor Maastrichtse alumni op een hoog niveau in het werk worden vereist vooral in de opleiding aan de UM zijn opgedaan.

Daarna wordt onderzocht welke onderwijsmethode en werkvormen in de opleiding in positieve zin bijdragen aan de verwerving van deze vijf competenties. Deze laatste analyse geeft een beeld van de manier waarop de leeromgeving bij kan dragen aan het verwerven van deze competenties. De analyses hebben betrekking op de meting die in het najaar van 2003 is gehouden onder alumni één jaar na afstuderen (afstudeercohort 200I/2002). De vragenlijst die aan deze afgestudeerden is voorgelegd, bevat namelijk de vraag in hoeverre competenties vooral binnen of vooral buiten de WO-opleiding zijn opgedaan.

\subsection{Achtergrond}

In Nederland wordt al lange tijd gedebatteerd over de inrichting van het onderwijs. In deze discussie spelen al enige tijd twee controverses een belangrijke rol (I) smal versus 
breed opleiden en (2) traditioneel onderwijs versus activerend onderwijs. Centraal in de discussie over smal en breed opleidingen staat de vraag of opleidingen afgestudeerden vakspecifieke of meer algemeen vormende kennis en vaardigheden moeten leren (Bishop, 1995; Borghans en de Grip, 1999; van Eijs en Ramaekers, 2002). Door het curriculum van een opleiding toe te spitsen op een specifiek beroep zouden volgens voorstanders van meer vakspecifiek onderwijs afgestudeerden optimaal worden voorbereid voor dit beroep. Afgestudeerden van vakspecifieke opleidingen zouden na het verlaten van de opleiding daarom onmiddellijk inzetbaar zijn. Dit veronderstelt dat recent afgestudeerden van beroepsgerichte opleidingen beroepsspecifieke competenties, zoals vakkennis en toepassen van vakkennis in de praktijk, vooral binnen de WO-opleiding hebben geleerd. Binnen de UM is met name de studie geneeskunde beroepsgericht van aard. Dit geldt in zekere mate ook voor de studie rechten.

Andere onderzoekers beweren daarentegen dat afgestudeerden van beroeps-gerichte opleidingen weinig flexibel zijn en daarom in sterke mate afhankelijk zijn van de werkgelegenheidsperspectieven in hun beroep. Doordat afgestudeerden van algemeen vormende opleidingen breder zijn opgeleid, zouden ze beter kunnen inspelen op de snel veranderende vraag-aanbod verhoudingen van verschillende beroepen (Borghans en de Grip, 1999). De studies economie, gezondheids-wetenschappen en psychologie zijn binnen de UM meer algemeen vormend van aard. Verwacht mag worden dat afgestudeerden van deze opleidingen generieke competenties als productief met anderen samenwerken en nieuwe dingen leren, relatief vaak binnen de WO-opleiding hebben geleerd.

In de discussie over conventioneel of activerend onderwijs staat de vraag centraal in hoeverre studenten op een zelfstandige manier kennis dienen te verwerven. Activerende onderwijsmethodes, zoals probleemgestuurd onderwijs (PGO), projectonderwijs (PO) en competentiegericht onderwijs (CGO) zijn relatief nieuw in het hoger onderwijs in Nederland. Deze onderwijsmethodes verschillen enigszins in de mate waarin de opleiding studenten een leeromgeving biedt waarin kennis toegepast moet worden in de context van realistische of gesimuleerde praktijksituaties. CGO gaat hierin het verst. Onderzoek waarin studenten uit een PGO leeromgeving worden vergeleken met studenten uit een conventionele leeromgeving laten zien dat studenten die PGO hebben gevolgd over het algemeen genomen beter zijn in het toepassen van kennis dan studenten die in een conventionele leeromgeving zitten (Dochy, e.a., 2003); Norman \& Schmidt, 2000). Wanneer de problemen of projecten sterk gebaseerd zijn op de latere beroepspraktijk van afgestudeerden zou dit betekenen dat activerende onderwijsvormen de directe inzetbaarheid van afgestudeerden kunnen verhogen. Daarnaast wordt verondersteld dat activerende onderwijs met name de generieke en reflectieve competenties stimuleren als zelfstandig leren, samenwerken en problemen analyseren en oplossen verwerven (Schmidt \& Moust, 1999). Zo bezien mag worden verwacht dat recent afgestudeerden van activerende onderwijsvormen relatief vaak competenties als het toepassen van vakkennis in de praktijk, nieuwe dingen leren, zelfstandig werken en met anderen samenwerken in de WO-opleiding hebben opgedaan. 


\subsection{Welke competenties worden vooral vereist en waar zijn deze geleerd?}

Zoals in de inleiding is aangegeven hebben we eerst voor afgestudeerden van elke faculteit van de UM de vijf meest voorkomende beroepen bepaald. Deze zijn in tabel 5.I weergegeven. Daarbij is ook het percentage afgestudeerden vermeld dat werkzaam is in het betreffende beroep. Afgestudeerden geneeskunde worden doorgaans arts (98 procent), en een groot deel van de afgestudeerden rechten is jurist (73 procent). Afgestudeerden van de FdEWB zijn meer over verschillende beroepen verdeeld. Zo is bijvoorbeeld het meest voorkomende beroep voor economen, met I9 procent, commercieel medewerker. Daarna volgen accountants (I3 procent), economen (IO procent), assistent accountants (Io procent) en organisatiedeskundigen ( 5 procent). Ook bij de FdGW en FdP zien we dat de afgestudeerden meer over verschillende beroepen zijn verdeeld.

Tabel 5.1

Overzicht van de vijf meest voorkomende beroepen van afgestudeerden van de UM, naar faculteit, in procenten, 2003

\begin{tabular}{|c|c|}
\hline $\begin{array}{l}\text { FdEWB } \\
\text { Commercieel medewerkers (19\%) } \\
\text { Accountants (13\%) } \\
\text { Economen (10\%) } \\
\text { Assistent accountants (10\%) } \\
\text { Organisatiedeskundigen (5\%) }\end{array}$ & $\begin{array}{l}\text { FdG } \\
\text { Artsen (98\%) }\end{array}$ \\
\hline $\begin{array}{l}\text { FdGW } \\
\text { Artsen (27\%) } \\
\text { Therapeuten en verpleegkundigen (9\%) } \\
\text { Sociaal-wetenschappelijk onderzoekers (8\%) } \\
\text { Medewerkers sociaal-cultureel werk (7\%) } \\
\text { Organisatiedeskundigen (5\%) }\end{array}$ & $\begin{array}{l}\text { FdP } \\
\text { Sociaal-wetenschappelijk onderzoekers (50\%) } \\
\text { Medewerkers sociaal-cultureel werk (16\%) } \\
\text { Docenten sociale vakken (3\%) } \\
\text { Sociaal wetenschappelijk medewerkers (3\%) } \\
\text { Organisatie-adviseurs (3\%) }\end{array}$ \\
\hline $\begin{array}{l}\text { FdR } \\
\text { Juristen (73\%) } \\
\text { Juridisch bestuurlijk medewerkers (3\%) } \\
\text { Assistent accountants (3\%) } \\
\text { Commerciële employees (1\%) } \\
\text { Onderwijskundigen en pedagogen (1\%) }\end{array}$ & \\
\hline
\end{tabular}

Het voorgaande liet zien in welke beroepen afgestudeerden vooral terecht zijn gekomen. Tabel 5.2 vermeldt welke vijf competenties in deze beroepen het vaakst op hoog niveau worden vereist (goed of uitmuntend). Voor alle faculteiten geldt dat afgestudeerden de competenties zelfstandig werkzaamheden uitvoeren en aan anderen duidelijk maken wat $\mathrm{u}$ bedoelt noemen als één van de vijf competenties die het vaakst op een hoog niveau worden vereist in het werk. Daarnaast dienen afgestudeerden van vier van de vijf faculteiten (FdEWB, FdG, FdP en FdR) in het werk de competentie hoofd- van bijzaken onderscheiden vaak op een hoog niveau te beheersen. Verder worden in het werk van afgestudeerden van de FdEWB, FdGW en FdR de competenties informatie vergaren en logisch redeneren vaak op een hoog niveau vereist. 
Bovenstaande competenties zijn voornamelijk generiek van aard. Eén uitzondering vinden we bij de FdG. Vakkennis toepassen in de praktijk wordt vaak op een hoog niveau vereist in het werk van afgestudeerden geneeskunde. Dit mag ook worden verwacht. Zoals eerder aangegeven is binnen de UM met name de studie geneeskunde beroepsgericht van aard.

\section{Tabel 5.2}

Competenties die het vaakst op een hoog niveau worden vereist in het werk en de plaats waar deze competenties vooral zijn geleerd, naar faculteit, in procenten, 2003

\begin{tabular}{|c|c|c|}
\hline & $\begin{array}{l}\text { Hoog niveau in } \\
\text { het werk vereist* }\end{array}$ & $\begin{array}{l}\text { Vooral geleerd in de } \\
\text { W0-opleiding }\end{array}$ \\
\hline \multicolumn{3}{|l|}{ FdEWB } \\
\hline vermogen om informatie te vergaren & 91 & 61 \\
\hline vermogen om zelfstandig de werkzaamheden uit te voeren & 87 & 54 \\
\hline vermogen om logisch te redeneren & 87 & 59 \\
\hline vermogen om hoofdzaken van bijzaken te onderscheiden & 87 & 53 \\
\hline vermogen om aan anderen duidelijk te maken wat u bedoelt & 84 & 59 \\
\hline \multicolumn{3}{|l|}{$\mathrm{FdG}$} \\
\hline vermogen om zelfstandig de werkzaamheden uit te voeren & 97 & 47 \\
\hline vermogen om vakkennis in de praktijk toe te passen & 95 & 65 \\
\hline vermogen om hoofdzaken van bijzaken te onderscheiden & 92 & 53 \\
\hline vermogen om nieuwe dingen te leren & 92 & 56 \\
\hline vermogen om aan anderen duidelijk te maken wat $u$ bedoelt & 92 & 60 \\
\hline \multicolumn{3}{|l|}{ FdGW } \\
\hline vermogen om zelfstandig de werkzaamheden uit te voeren & 98 & 59 \\
\hline vermogen om verbanden leggen tussen verschillende zaken & 90 & 71 \\
\hline vermogen om logisch te redeneren & 88 & 48 \\
\hline vermogen om aan anderen duidelijk te maken wat u bedoelt & 85 & 39 \\
\hline vermogen om nieuwe ideeën en oplossingen te bedenken & 82 & 30 \\
\hline \multicolumn{3}{|l|}{$\mathrm{FdP}$} \\
\hline vermogen om aan anderen duidelijk te maken wat $u$ bedoelt & 96 & 57 \\
\hline vermogen om informatie te vergaren & 93 & 64 \\
\hline vermogen om zelfstandig de werkzaamheden uit te voeren & 93 & 61 \\
\hline vermogen om hoofdzaken van bijzaken te onderscheiden & 89 & 68 \\
\hline bereidheid om op te komen voor het eigen standpunt & 89 & 61 \\
\hline \multicolumn{3}{|l|}{ FdR } \\
\hline vermogen om zelfstandig de werkzaamheden uit te voeren & 94 & 61 \\
\hline vermogen om logisch te redeneren & 92 & 53 \\
\hline vermogen om aan anderen duidelijk te maken wat $u$ bedoelt & 92 & 42 \\
\hline vermogen om hoofdzaken van bijzaken te onderscheiden & 91 & 57 \\
\hline vermogen om informatie te vergaren & 87 & 61 \\
\hline
\end{tabular}

In hoeverre hebben afgestudeerden de competenties die in het werk het vaakst op een hoog niveau worden vereist vooral geleerd in de opleiding aan de UM? Dit is ook in tabel 5.2 vermeld. Zo blijkt onder meer dat 6I procent van de afgestudeerde economen de competentie informatie vergaren vooral in de WO-opleiding heeft opgedaan. Bij het merendeel van de competenties zegt 50 á 60 procent van de afgestudeerden 
dat de competentie vooral is verworven in de WO-opleiding. Enige uitzondering is de FdGW waar dit aandeel nogal uiteen loopt voor de vijf competenties. In totaal 7I procent van de gezondheidswetenschappers zegt dat de competentie verbanden leggen tussen verschillende zaken vooral is geleerd in de WO-opleiding. Daarentegen geeft slechts 30 procent van de gezondheids-wetenschappers aan dat nieuwe ideeën en oplossingen bedenken vooral zijn geleerd in de WO-opleiding.

Eerder hebben we verondersteld dat vooral recent afgestudeerden van beroepsgerichte opleidingen aangeven dat vakspecifieke competenties vooral binnen de WO-opleiding zijn geleerd. Afgestudeerden van algemeen vormende opleidingen zouden vaker aangeven dat generieke competenties vooral binnen de WO-opleiding zijn opgedaan. Deze veronderstelling komt deels naar voren uit tabel 5.2. Zo geven afgestudeerden van beroepsgerichte opleidingen $(\mathrm{FdG})$ minder vaak dan afgestudeerden van andere opleidingen aan dat de competentie zelfstandig werkzaamheden uitvoeren vooral in de WO-opleiding is geleerd. Daarnaast geldt dat afgestudeerden van de FdG de vakspecifieke competentie vakkennis toepassen in de praktijk vaker vooral in de WO-opleiding hebben geleerd dan de andere, meer algemeen vormende competenties. Voor het overige vinden we weinig indicaties voor verschillen in smal en breed opleiden.

\subsection{De bijdrage van de onderwijsmethode en werkvormen aan de verwerving van competenties}

In deze paragraaf wordt onderzocht in hoeverre verschillende onderwijsvormen en werkvormen in de opleiding bijdragen aan de verwerving van competenties die vaak op een hoog niveau worden vereist in het werk. In tegenstelling tot eerdere analyses hebben we hier gebruik gemaakt van gegevens van de WO-Monitor. Daarvan zijn gegevens gebruikt van recent afgestudeerden economie, geneeskunde, gezondheidswetenschappen, psychologie en rechten van alle universiteiten in Nederland. Het gaat hier alléén om afgestudeerden van opleidingen die zowel door de UM als door andere universiteiten worden aangeboden. 5 Dit is gedaan omdat binnen de groep afgestudeerden van de UM weinig variatie bestaat in de gevolgde onderwijsmethode. Alle afgestudeerden van de UM hebben PGO gevolgd (zie tabel 5.3). Op deze manier wordt duidelijk in hoeverre activerend onderwijs en traditioneel onderwijs verschillen in de bijdrage aan de verwerving van competenties die op een hoog niveau worden vereist in het werk van recent afgestudeerden.

Aan de afgestudeerden is gevraagd voor drie activerende onderwijsmethodes (PGO, $\mathrm{PO}$ en $\mathrm{CGO}$ ) aan te geven of ze gedurende de WO-opleiding volgens deze onderwijsmethode les hebben gehad (antwoordcategorieën ja/nee/onbekend). Daarnaast hebben de afgestudeerden voor een aantal werkvormen kunnen aangeven in hoeverre deze werden benadrukt in de WO-opleiding (antwoordcategorieën zeer weinig I tot

5. Dit zijn afgestudeerden van de opleidingen geneeskunde, gezondheidswetenschappen, Nederlands recht, fiscaal recht, economie, fiscale economie, econometrie, bedrijfskunde en psychologie. 
en met 5 zeer veel). In tabel 5.3 zijn de antwoorden vermeld die afgestudeerden van de UM en andere universiteiten hebben gegeven omtrent de onderwijsmethode en werkvormen in de WO-opleiding. Hierbij is opnieuw geselecteerd op afgestudeerden die werkzaam zijn in de meest voorkomende beroepen waarin afgestudeerden van de UM werkzaam zijn.

Zoals gezegd hebben alle afgestudeerden van de UM activerend onderwijs gevolgd. Het gaat daarbij altijd om PGO, soms gecombineerd met PO en CGO. Voor de andere universiteiten geldt dat 46 procent van de afgestudeerden een vorm van activerend onderwijs heeft gevolgd tijdens de WO-opleiding. In totaal is echter 54 procent van de afgestudeerden van andere universiteiten tijdens de opleiding niet in aanraking gekomen met activerend onderwijs. Dit blijkt ook uit de nadruk die in de opleiding wordt gelegd op werkvormen. Bij de UM wordt volgens afgestudeerden veel meer nadruk gelegd op groepsopdrachten en vaardigheidstrainingen. Bij de andere universiteiten ligt in de opleiding veel meer de nadruk op hoorcollege's dan bij de UM.

\section{Tabel 5.3}

Overzicht van gevolgde onderwijsmethode en werkvormen, naar universiteit, in procenten, 2003

\begin{tabular}{|c|c|c|}
\hline & $\begin{array}{c}\text { UM } \\
(N=309)\end{array}$ & $\begin{array}{l}\text { Andere universiteiten* } \\
\qquad(\mathrm{N}=606)\end{array}$ \\
\hline \multicolumn{3}{|l|}{ Gevolgde onderwijsmethode } \\
\hline Geen PGO, PO of CGO & 0 & 54 \\
\hline Alléén PGO & 84 & 15 \\
\hline Alléén P0 & 0 & 6 \\
\hline Alléén CGO & 0 & 4 \\
\hline$P G 0$ en $P 0$ & 9 & 9 \\
\hline PGO en $C_{G 0}$ & 3 & 4 \\
\hline PO en CGO & 0 & 2 \\
\hline$P G 0, P 0$ en $C G 0$ & 4 & 6 \\
\hline \multicolumn{3}{|l|}{ Veel nadruk in de opleiding** } \\
\hline Hoorcollege's & 12 & 74 \\
\hline Werkcollege's & 40 & 52 \\
\hline Groepsopdrachten & 77 & 29 \\
\hline Vaardigheidstrainingen & 62 & 17 \\
\hline Practica & 41 & 28 \\
\hline Schrijf/onderzoeksopdracht & 48 & 29 \\
\hline Zelfstudie & 91 & 78 \\
\hline Stages & 34 & 27 \\
\hline Afstudeerscriptie & 58 & 51 \\
\hline \multicolumn{3}{|c|}{$\begin{array}{l}\text { * gebaseerd op cijfers van afgestudeerden van Universiteit Leiden, } \\
\text { Rotterdam, Vrije Universiteit Amsterdam en Universiteit van Tilburg } \\
\text { ** aandeel alumni met score } 4 \text { en } 5 \text { op een schaal van } 1 \text { tot } 5 \text { zeer wein }\end{array}$} \\
\hline
\end{tabular}

In het vervolg van dit hoofdstuk maken we wat betreft de onderwijsmethode een onderscheid tussen afgestudeerden die "een vorm" van activerend onderwijs hebben gevolgd (PGO, PO en/of CGO) en afgestudeerden die geen enkele vorm van activerend onderwijs hebben gevolgd. Dit is gedaan omdat we de analyses apart uitvoeren voor afgestudeerden economie, geneeskunde, gezondheidsweten-schappen, psycho- 
logie en rechten. Hierdoor zijn de aantallen te klein om binnen de verschillende onderwijsmethoden nog een onderscheid te kunnen maken.

Economen

Tabel 5.4 toont weer de vijf competenties die economen van de UM het vaakst op een hoog niveau dienen te beheersen in het werk. Daarbij is vermeld in hoeverre deze competenties vooral in de WO-opleiding zijn opgedaan. Dit is allereerst weergegeven voor afgestudeerden die activerend onderwijs hebben gevolgd (ja) en voor afgestudeerden die geen activerend onderwijs hebben gevolgd (nee).

\section{Tabel 5.4}

Aandeel afgestudeerden economie dat aangeeft competenties* vooral te hebben geleerd in het onderwijs, naar gevolgde onderwijsmethode en werkvorm, 2003

\begin{tabular}{|c|c|c|c|c|c|}
\hline Economie $^{* *}$ & $\begin{array}{l}\text { informatie } \\
\text { vergaren }\end{array}$ & $\begin{array}{c}\text { zelfstandig } \\
\text { werkzaamheden } \\
\text { uitvoeren }\end{array}$ & $\begin{array}{l}\text { logisch } \\
\text { redeneren }\end{array}$ & $\begin{array}{c}\text { anderen duidelijk } \\
\text { maken wat u } \\
\text { bedoelt }\end{array}$ & $\begin{array}{l}\text { hoofd- van } \\
\text { bijzaken } \\
\text { onderscheiden }\end{array}$ \\
\hline \multicolumn{6}{|l|}{ Activerend onderwijs } \\
\hline Nee & 46 & 52 & 63 & 21 & 46 \\
\hline Ja & 53 & 60 & 60 & 40 & 52 \\
\hline \multicolumn{6}{|l|}{ Veel nadruk in opleiding } \\
\hline Hoorcollege's & 42 & 54 & 55 & 27 & 47 \\
\hline Werkcollege's & 54 & 53 & 56 & 37 & 49 \\
\hline Groepsopdrachten & 55 & 55 & 58 & 40 & 44 \\
\hline Vaardigheidstrainingen & 67 & 61 & 62 & 57 & 54 \\
\hline Practica & 61 & 53 & 66 & 37 & 51 \\
\hline Schrijf/onderzoeksopdracht & 60 & 53 & 57 & 39 & 54 \\
\hline Zelfstudie & 49 & 53 & 56 & 34 & 46 \\
\hline Stages & 61 & 57 & 64 & 36 & 50 \\
\hline Afstudeerscriptie & 53 & 57 & 56 & 36 & 49 \\
\hline
\end{tabular}

* Betreft competenties die in de vijf voornaamste beroepen van afgestudeerden economie van de UM het vaakst worden vereist door de werkgever

** Betreft afgestudeerden economie van 4 Nederlandse universiteiten; aandeel economen dat zegt dat de betreffende competentie vooral binnen de WO-opleiding zijn geleerd

Bron: ROA

Over het algemeen zeggen economen die activerend onderwijs hebben gevolgd vaker dan economen die geen activerend onderwijs hebben gevolgd dat deze vijf competenties in de WO-opleiding zijn geleerd. Dit is ook wat mag worden verwacht aangezien we hebben verondersteld dat generieke en reflectieve competenties meer worden gestimuleerd in activerend onderwijs dan in traditioneel onderwijs. Daarbij blijkt uit tabel 5.4 dat activerend onderwijs met name bij de competentie anderen duidelijk maken wat u bedoelt beter 'scoort' dan traditioneel onderwijs. Enige uitzondering is hier de competentie logisch redeneren waar juist afgestudeerden die geen activerend onderwijs hebben gevolgd net iets vaker zeggen dat ze deze competentie vooral hebben geleerd in de WO-opleiding.

In tabel 5.4 is ook de relatie weergegeven tussen de nadruk die tijdens de opleiding is gelegd op werkvormen en de mate waarin competenties vooral zijn geleerd in de opleiding. Voor afgestudeerden die aangeven dat de betreffende werkvorm (veel) werd 
benadrukt in de opleiding is het aandeel vermeld dat zegt dat de competentie vooral is verworven in de WO-opleiding. Aan de hand hiervan kan bijvoorbeeld worden bepaald of afgestudeerden die veel vaardigheidstrainingen hebben gehad in de opleiding de competentie informatie vergaren vaak in de WO-opleiding hebben verworven. Dit blijkt inderdaad het geval te zijn. In totaal 67 procent van de economen die zeggen dat vaardigheidstrainingen werden benadrukt in de WO-opleiding vindt dat informatie vergaren vooral is geleerd in de WO-opleiding. Ter vergelijking: 42 procent van de economen die zeggen dat hoorcollege's werden benadrukt in de WO-opleiding geeft aan dat informatie vergaren vooral is geleerd in de WO-opleiding.

Overigens blijkt uit tabel 5.4 dat een meer traditionele onderwijsvorm als hoorcollege's relatief weinig bijdraagt aan de verwerving van competenties die op een hoog niveau worden vereist in het werk van economen. Het zijn met name vaardigheidstrainingen, practica, schrijf/onderzoeksopdrachten en stages die hieraan een positieve bijdrage leveren. De grootste verschillen vinden we hier bij de competentie aan anderen duidelijk maken wat u bedoelt. Slechts 27 procent van de economen die zeggen dat hoorcollege's werden benadrukt in de WO-opleiding geeft aan dat deze competentie vooral is geleerd in de WO-opleiding, tegen 57 procent van de economen die aangeven dat vaardigheidstrainingen werden benadrukt.

\section{Geneeskunde}

Ook bij geneeskunde vinden we tussen afgestudeerden die activerend onderwijs hebben gevolgd en afgestudeerden die traditioneel onderwijs hebben gevolgd aanzienlijke verschillen in de mate waarin competenties vooral in de WO-opleiding hebben geleerd. Deze competenties hebben medici die activerend onderwijs hebben gevolgd veel vaker opgedaan in de WO-opleiding dan medici die geen activerend onderwijs hebben gevolgd. Dit verschil tussen activerend en traditioneel onderwijs is bij medici nog een stuk groter dan bij economen. Dit geldt vooral voor de competentie vakkennis toepassen in de praktijk, waar 56 procent van degenen met activerend onderwijs zegt deze competentie vooral in de WO-opleiding te hebben geleerd, tegen 29 procent van degenen met traditioneel onderwijs. Bij de andere competenties, met uitzondering van de competentie hoofd- van bijzaken onderscheiden, is dit verschil tussen activerend en traditioneel onderwijs groter dan 20 procent. Daarmee kan worden geconcludeerd dat activerend onderwijs voor recent afgestudeerden geneeskunde in veel sterkere mate dan voor recent afgestudeerden economie bijdraagt aan de verwerving van competenties die in het werk op een hoog niveau worden vereist.

Bovendien geldt ook voor afgestudeerden geneeskunde dat hoorcollege's in mindere mate bijdragen dan andere werkvormen aan de vijf competenties die op een hoog niveau worden vereist in het werk van medici. Het blijkt dat met name groepsopdrachten en vaardigheidstrainingen bijdragen aan de verwerving in de WO-opleiding van deze vijf competenties. Daarnaast zien we dat bij geneeskunde de afstudeerscriptie relatief weinig bijdraagt aan de verwerving van de vijf competenties. Afstudeerscripties 
zijn in het curriculum van de opleiding geneeskunde ook minder gebruikelijk dan in het curriculum van andere opleidingen als bijvoorbeeld economie of gezondheidswetenschappen.

\section{Tabel 5.5}

Aandeel afgestudeerden geneeskunde dat aangeeft competenties* vooral te hebben geleerd in het onderwijs, naar gevolgde onderwijsmethode en werkvorm, 2003

\begin{tabular}{|c|c|c|c|c|c|}
\hline Geneeskunde** & $\begin{array}{c}\text { zelfstandig } \\
\text { werkzaamheden } \\
\text { uitvoeren }\end{array}$ & $\begin{array}{c}\text { vakkennis } \\
\text { toepassen } \\
\text { in de praktijk }\end{array}$ & $\begin{array}{c}\text { hoofd-van } \\
\text { bijzaken } \\
\text { onderscheiden }\end{array}$ & $\begin{array}{l}\text { nieuwe dingen } \\
\text { leren }\end{array}$ & $\begin{array}{c}\text { anderen duidelijk } \\
\text { maken wat u } \\
\text { bedoelt }\end{array}$ \\
\hline \multicolumn{6}{|l|}{ Activerend onderwijs } \\
\hline Nee & 15 & 29 & 40 & 23 & 23 \\
\hline $\mathrm{Ja}$ & 40 & 56 & 47 & 46 & 45 \\
\hline \multicolumn{6}{|l|}{ Veel nadruk in opleiding } \\
\hline Hoorcollege's & 29 & 47 & 43 & 38 & 32 \\
\hline Werkcollege's & 36 & 53 & 43 & 46 & 40 \\
\hline Groepsopdrachten & 36 & 58 & 48 & 47 & 50 \\
\hline Vaardigheidstrainingen & 41 & 54 & 45 & 48 & 45 \\
\hline Practica & 33 & 50 & 43 & 42 & 37 \\
\hline Schrijf/onderzoeksopdracht & 32 & 53 & 45 & 35 & 25 \\
\hline Zelfstudie & 34 & 49 & 45 & 43 & 37 \\
\hline Stages & 34 & 51 & 45 & 45 & 41 \\
\hline Afstudeerscriptie & 22 & 43 & 33 & 31 & 24 \\
\hline
\end{tabular}

* Betreft competenties die in de het voornaamste beroep (arts) van afgestudeerden geneeskunde van de UM het vaakst worden vereist door de werkgever

** Betreft afgestudeerden geneeskunde van 5 Nederlandse universiteiten; aandeel dat zegt dat de betreffende competentie vooral binnen de WO-opleiding zijn geleerd Bron: ROA

\section{Gezondheidswetenschappen}

Bij gezondheidswetenschappen kan geen vergelijking worden gemaakt tussen afgestudeerden die traditioneel en activerend onderwijs hebben gevolgd, omdat de aantallen afgestudeerden die traditioneel onderwijs hebben gevolgd hier te klein zijn. Wel blijkt dat relatief veel afgestudeerden gezondheidswetenschappen die activerend onderwijs hebben gevolgd, aangeven dat de competenties zelfstandig werken en verbanden leggen vooral zijn geleerd in het onderwijs, terwijl dit percentage bij de competentie nieuwe ideeën en oplossingen bedenken relatief laag is. Dit laatste is op zich niet vreemd wanneer je bedenkt dat deze competentie een indicatie is voor creativiteit. Creativiteit is over het algemeen vrij moeilijk te leren.

Bij de werkvormen zien we opnieuw dat vooral groepsopdrachten en vaardigheidstrainingen relatief veel en hoorcollege's relatief weinig bijdragen aan de verwerving van de vijf competenties die het vaakst op een hoog niveau worden vereist in het werk van gezondheidswetenschappers. Verder draagt voornamelijk de afstudeerscriptie in positieve zin aan de verwerving van deze competenties in de opleiding. 
Tabel 5.6

Aandeel afgestudeerden gezondheidswetenschappen dat aangeeft competenties* vooral te hebben geleerd in het onderwijs, naar gevolgde onderwijsmethode en werkvorm, 2003

$\begin{array}{lccccc}\text { Gezondheidswetenschappen** } & \begin{array}{c}\text { zelfstandig } \\ \text { werkzaamheden } \\ \text { uitvoeren }\end{array} & \begin{array}{c}\text { verbanden } \\ \text { leggen }\end{array} & \begin{array}{c}\text { logisch } \\ \text { redeneren }\end{array} & \begin{array}{c}\text { anderen duidelijk } \\ \text { maken wat u } \\ \text { bedoelt }\end{array} & \begin{array}{c}\text { nieuwe ideeën } \\ \text { en oplossingen } \\ \text { bedenken }\end{array} \\ \begin{array}{l}\text { Activerend onderwijs } \\ \text { Nee }\end{array} & \mathrm{X} & \mathrm{x} & \mathrm{x} & \mathrm{x} & \mathrm{x} \\ \mathrm{Ja} & 63 & 72 & 49 & 43 & 29 \\ \text { Veel nadruk in opleiding } & & & & & \\ \text { Hoorcollege's } & 56 & 51 & 38 & 31 & 26 \\ \text { Werkcollege's } & 49 & 62 & 47 & 42 & 32 \\ \text { Groepsopdrachten } & 58 & 80 & 51 & 46 & 30 \\ \text { Vaardigheidstrainingen } & 63 & 70 & 52 & 48 & 33 \\ \text { Practica } & 59 & 63 & 42 & 42 & 32 \\ \text { Schrijf/onderzoeksopdracht } & 56 & 62 & 43 & 38 & 32 \\ \text { Zelfstudie } & 54 & 64 & 44 & 40 & 34 \\ \text { Stages } & 44 & 53 & 53 & 37 & 31 \\ \text { Afstudeerscriptie } & 52 & 71 & 52 & 42 & 35\end{array}$

* Betreft competenties die in de vijf voornaamste beroepen van afgestudeerden gezondheidswetenschappen van de UM het vaakst worden vereist door de werkgever

** Betreft afgestudeerden gezondheidswetenschappen van 3 Nederlandse universiteiten; aandeel dat zegt dat de betreffende competentie vooral binnen de WO-opleiding zijn geleerd

$\mathrm{x}=$ te kleine aantallen

Bron: ROA

\section{Psychologie}

In tabel 5.7 zijn de resultaten weergegeven voor afgestudeerden psychologie. Hier blijkt dat activerend onderwijs, in vergelijking met traditioneel onderwijs, veel meer bijdraagt aan de verwerving van de competenties informatie vergaren, zelfstandig werken en hoofd- van bijzaken onderscheiden. Voor de competenties anderen duidelijk maken wat u bedoelt en opkomen voor het eigen standpunt geldt dat deze minder eenvoudig zijn te leren in het onderwijs. Het aandeel afgestudeerde psychologen dat zegt deze competenties vooral in de WO-opleiding te hebben geleerd is relatief laag. Hetzelfde zien we overigens ook bij afgestudeerden economie, geneeskunde en gezondheidswetenschappen. Desalniettemin worden de competenties anderen duidelijk maken wat u bedoelt en opkomen voor het eigen standpunt vaker verworven via activerend onderwijs dan via traditioneel onderwijs. Bovendien dragen vooral werkvormen als groepsopdrachten, practica en vaardigheidstrainingen bij aan de verwerving van deze competenties.

Voor psychologen geldt ook dat hoorcollege's niet in positieve zin bijdragen aan de verwerving van competenties die het vaakst op een hoog niveau worden vereist in het werk. Voor psychologen geldt dat vooral practica bijdragen aan deze competenties, en dat geldt dan met name voor de competenties aan anderen duidelijk maken wat $\mathrm{u}$ bedoelt en zelfstandig werkzaamheden uitvoeren. Daarnaast blijkt ook hier dat vaardigheidstrainingen relatief veel bijdragen aan competenties die door psychologen op een hoog niveau worden vereist in het werk. 
Tabel 5.7

Aandeel afgestudeerden psychologie dat aangeeft competenties* vooral te hebben geleerd in het onderwijs, naar gevolgde onderwijsmethode en werkvorm, 2003

$\begin{array}{lccccc}\text { Psychologie** } & \begin{array}{c}\text { anderen duidelijk } \\ \text { maken wat u } \\ \text { bedoelt }\end{array} & \begin{array}{c}\text { informatie } \\ \text { vergaren }\end{array} & \begin{array}{c}\text { zelfstandig } \\ \text { werkzaamheden } \\ \text { uitvoeren }\end{array} & \begin{array}{c}\text { hoofd- van } \\ \text { bijzaken } \\ \text { onderscheiden }\end{array} & \begin{array}{c}\text { opkomen voor het } \\ \text { eigen standpunt }\end{array} \\ \begin{array}{l}\text { Activerend onderwijs } \\ \text { Nee }\end{array} & 24 & 48 & 50 & 40 & 24 \\ \text { Ja } & 36 & 68 & 66 & 62 & 34 \\ \text { Veel nadruk in opleiding } & 33 & 51 & 50 & 51 & 30 \\ \text { Hoorcollege's } & 47 & 53 & 63 & 62 & 40 \\ \text { Werkcollege's } & 43 & 50 & 56 & 60 & 47 \\ \text { Groepsopdrachten } & 55 & 63 & 68 & 68 & 45 \\ \text { Vaardigheidstrainingen } & 61 & 52 & 74 & 68 & 45 \\ \text { Practica } & 41 & 56 & 63 & 59 & 39 \\ \text { Schrijf/onderzoeksopdracht } & 39 & 57 & 54 & 55 & 33 \\ \text { Zelfstudie } & 43 & 50 & 51 & 54 & 28 \\ \text { Stages } & 40 & 55 & 53 & 56 & 35 \\ \text { Afstudeerscriptie } & 45 & & & & \\ \end{array}$

* Betreft competenties die in de vijf voornaamste beroepen van afgestudeerden psychologie van de UM het vaakst worden vereist door de werkgever

** Betreft afgestudeerden psychologie van 5 Nederlandse universiteiten; aandeel dat zegt dat de betreffende competentie vooral binnen de WO-opleiding zijn geleerd Bron: ROA

Tabel 5.8

Aandeel afgestudeerden rechten dat aangeeft competenties* vooral te hebben geleerd in het onderwijs, naar gevolgde onderwijsmethode en werkvorm, 2003

\begin{tabular}{|c|c|c|c|c|c|}
\hline Rechten $* *$ & $\begin{array}{c}\text { zelfstandig } \\
\text { werkzaamheden } \\
\text { uitvoeren }\end{array}$ & $\begin{array}{l}\text { logisch } \\
\text { redeneren }\end{array}$ & $\begin{array}{l}\text { anderen duidelijk } \\
\text { maken wat u } \\
\text { bedoelt }\end{array}$ & $\begin{array}{c}\text { hoofd- van } \\
\text { bijzaken } \\
\text { onderscheiden }\end{array}$ & $\begin{array}{c}\text { informatie } \\
\text { vergaren }\end{array}$ \\
\hline \multicolumn{6}{|l|}{ Activerend onderwijs } \\
\hline Nee & 57 & 54 & 32 & 53 & 47 \\
\hline Ja & 56 & 58 & 30 & 62 & 60 \\
\hline \multicolumn{6}{|l|}{ Veel nadruk in opleiding } \\
\hline Hoorcollege's & 55 & 55 & 32 & 58 & 54 \\
\hline Werkcollege's & 53 & 52 & 32 & 52 & 55 \\
\hline Groepsopdrachten & 55 & 49 & 41 & 49 & 50 \\
\hline Vaardigheidstrainingen & 65 & 61 & 43 & 61 & 60 \\
\hline Practica & 70 & 53 & 48 & 67 & 52 \\
\hline Schrijf/onderzoeksopdracht & 57 & 60 & 49 & 59 & 57 \\
\hline Zelfstudie & 55 & 54 & 33 & 56 & 52 \\
\hline Stages & 56 & 72 & 59 & 78 & 76 \\
\hline Afstudeerscriptie & 55 & 55 & 35 & 60 & 60 \\
\hline
\end{tabular}

* Betreft competenties die in de vijf voornaamste beroepen van afgestudeerden rechten van de UM het vaakst worden vereist door de werkgever

** Betreft afgestudeerden rechten van 6 Nederlandse universiteiten; aandeel dat zegt dat de betreffende competentie vooral binnen de WO-opleiding zijn geleerd Bron: ROA

\section{Rechten}

Voor Rechten geldt dat er in vergelijking met andere opleidingen relatief weinig verschillen bestaan tussen activerend en traditioneel onderwijs in de mate waarin de vijf competenties zijn verworven in de opleiding. Alleen bij de competenties hoofd- 
van bijzaken onderscheiden en informatie vergaren vinden we redelijke verschillen tussen degenen die activerend onderwijs hebben gevolgd en degenen die traditioneel onderwijs hebben gevolgd. Daarbij hebben juristen die activerend onderwijs hebben gevolgd beide competenties vaker verworven in de WO-opleiding dan juristen die traditioneel onderwijs hebben gevolgd.

Wat betreft de werkvormen zien we dat vooral stages in positieve zin bijdragen aan de verwerving van competenties die op een hoog niveau worden vereist in het werk van juristen. Voor alle vijf competenties, met uitzondering van zelfstandig werkzaamheden uitvoeren, geldt dat met name stages hebben bijgedragen aan de verwerving van deze competenties in de WO-opleiding. Bij zelfstandig werkzaamheden uitvoeren zijn het vooral practica en vaardigheidstrainingen die in positieve zin bijdragen aan de verwerving van deze competentie in de opleiding.

\subsection{Conclusie}

In dit hoofdstuk zijn voor afgestudeerden van elke faculteit van de UM eerst de vijf meest voorkomende beroepen bepaald. Daarna zijn voor deze beroepen de vijf competenties bepaald die het vaakst op het hoog niveau worden vereist in het werk. Bekeken is of recent afgestudeerden van de UM deze competenties vooral in de WOopleiding hebben geleerd. Dit blijkt deels het geval te zijn. Bij het merendeel van deze competenties zegt 50 á 60 procent van de afgestudeerden dat de competentie vooral is geleerd in de WO-opleiding. Een uitzondering is hier de FdGW waar dit aandeel sterk uiteen loopt voor de vijf competenties, van 7I procent bij de competentie verbanden leggen tussen verschillende zaken tot 30 procent bij de competentie nieuwe ideeën en oplossingen bedenken.

Vervolgens is onderzocht op welke manier de leeromgeving (onderwijsmethode en werkvormen) bij kan dragen aan het verwerven van deze competenties. Hiervoor zijn gegevens gebruikt van recent afgestudeerden economie, geneeskunde, gezondheidswetenschappen, psychologie en rechten van alle universiteiten in Nederland. Op deze manier kunnen activerende en traditionele onderwijsmethoden worden vergeleken wat betreft hun bijdrage aan de verwerving van competenties die op een hoog niveau worden vereist in het werk. Hieruit is naar voren gekomen dat afgestudeerden die activerend onderwijs hebben gevolgd vaker zeggen dat deze competenties in de WO-opleiding zijn geleerd dan afgestudeerden die geen activerend onderwijs hebben gevolgd. Dit verschil tussen activerend onderwijs en traditioneel onderwijs is het grootst bij recent afgestudeerde medici. Bij recent afgestudeerde juristen is dit verschil ook aanwezig, maar relatief klein.

Wat betreft de werkvormen in de opleiding blijkt dat vooral groepsopdrachten, vaardigheidstrainingen en practica bijdragen aan competenties die op een hoog niveau worden vereist in het werk. Daarnaast leveren bij economen en juristen stages en 
bij gezondheidswetenschappers de afstudeerscriptie een belangrijke bijdrage aan de verwerving van deze competenties. Een meer traditionele onderwijsvorm als hoorcollege's draagt daarentegen in mindere mate bij aan de verwerving van competenties die op een hoog niveau worden vereist in het werk. Al met al kan hieruit worden geconcludeerd dat activerend onderwijs, zoals probleemgestuurd onderwijs (PGO), in veel grotere mate dan traditioneel onderwijs bijdraagt aan de verwerving van competenties die op een hoog niveau worden vereist in het werk. 



\section{Literatuur}

Bishop, J.H. (1995), Vocational training and at-risk youth in the United States, in: Vocational training European Journal 6, 34-42.

Borghans, L. \& A. de Grip (1999), 'Smal en breed opleiden: productiviteit versus flexibiliteit', in: Gids voor de opleidingspraktijk 28, 1-33.

Dochy, F., Segers, M., van den Bossche, P. and Gijbels, D. (2003), Effects of problem-based learning: a meta analysis. Learning and Instruction, 13, 533-568.

Eijs, van P. \& Ramaekers, G. (2002), Flexibiliteit op de arbeidsmarkt, in: Tijdschrift voor Hoger Onderwijs 20 (1), 32-41.

Norman, G.R. \& Schmidt, H.G. (2000), Effectiveness of problem based learning curricula: theory, practice and paper darts. Medical Education, 34 (9), 721-728.

Schmidt, H.G. \& Moust, J.H.C. (1999), Probleemgestuurd onderwijs, praktijk en theorie. HORreeks. Groningen: Wolters-Noordhoff. 



\section{Bijlage}

In deze bijlage wordt ingegaan op de respons van de meest recente metingen onder alumni van de UM die één, vijf en tien jaar eerder de opleiding hebben verlaten.

Tabel B.I geeft een overzicht van het aantal alumni en de respons van de meting die eind 2003 heeft plaatsgevonden onder alumni één jaar na afstuderen (cohort 200I2002) en de meting die in het voorjaar van 2004 heeft plaatsgevonden onder alumni vijf en tien jaar na afstuderen (cohort I992-1993 en cohort I997-I998).

Tabel B.1

Responscijfers recente metingen

\begin{tabular}{lcccccc} 
& \multicolumn{2}{c}{ Cohort 1992-1993 } & \multicolumn{2}{c}{ Cohort 1997-1998 } & \multicolumn{2}{c}{ Cohort 2001-2002 } \\
& Aantal & Respons & Aantal & Respons & Aantal & Respons \\
alumni & $\%$ & alumni & $\%$ & alumni & $\%$ \\
FdAW & n.v.t. & n.v.t. & 14 & 21 & 5 & 40 \\
FdCW & n.v.t. & n.v.t. & 28 & 39 & 50 & 14 \\
FdEWB & 192 & 34 & 311 & 39 & 464 & 29 \\
FdG & 172 & 72 & 251 & 59 & 202 & 31 \\
FdGW & 381 & 44 & 306 & 49 & 434 & 38 \\
FdP & n.v.t. & n.v.t. & n.v.t. & n.v.t. & 94 & 40 \\
FdR & 194 & 42 & 231 & 29 & 269 & 30 \\
Totaal & 1.048 & 42 & 1.251 & 40 & 1.518 & 32
\end{tabular}

Bron: ROA

Tabel B.2 geeft een overzicht van het aantal alumni en de respons van de meting die eind 2004 heeft plaatsgevonden onder alumni één jaar na afstuderen (cohort 20022003) en de meting die in het voorjaar van 2005 heeft plaatsgevonden onder alumni vijf en tien jaar na afstuderen (cohort I993-I994 en cohort 1998-I999).

Tabel B.2

Responscijfers recente metingen

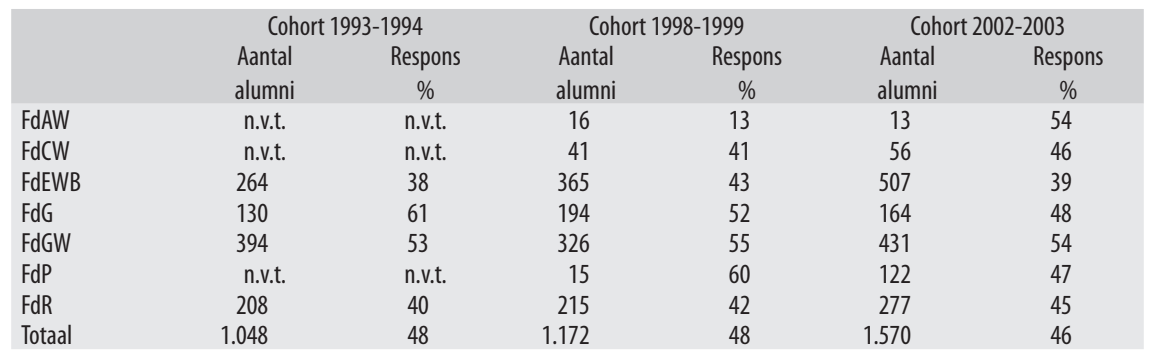

Bron: ROA 
De respons onder Maastrichtse alumni die vijf en tien jaar eerder zijn afgestudeerd is hoog in vergelijking met voorgaande metingen. Een belangrijke factor die heeft meegespeeld bij de hogere respons onder afgestudeerden is dat voor het eerst gebruik is gemaakt van het adressenbestand van het alumnibureau van het Studentservicecentrum (SSC). Het SSC beschikt over een adressenbestand met een hoge actualiteitswaarde, waardoor we meer alumni van de UM hebben kunnen benaderen. Bij de meting eind 2003 onder afgestudeerden die één jaar eerder de opleiding hebben verlaten, is hiervan nog geen gebruik gemaakt. De respons ligt hier met 32 procent ook vrij laag. In de hier opvolgende meting eind 2004 is dit wel gebeurd waardoor de responspercentage onder alumni één jaar na het verlaten van de opleiding dan ook een flink stuk hoger liggen (zie tabel B.2).

Overigens mag niet onvermeld blijven dat voor cohort I998-I999 van de 4I benaderde afgestudeerden van de FdCW I7 afgestudeerden hebben meegedaan aan het onderzoek. Dit is te weinig om een representatief beeld te kunnen geven van afgestudeerden van deze faculteit. Gevolg hiervan is dat in de tabellen van hoofdstuk 2 en hoofdstuk 3 van dit rapport geen cijfers worden vermeld voor de FdCW voor cohort I998-I999. Hetzelfde geldt voor de FdP en de FdAW.

Verder wordt er in dit rapport gebruik gemaakt van twee gekoppelde bestanden. Voor het cohort 1998-1999 zijn de resultaten van de meting één jaar na afstuderen in 2000 en de meting vijf jaar na afstuderen in 2005 aan elkaar gekoppeld. Voor het cohort I993-I994 zijn de resultaten van de meting één jaar na afstuderen in 1995 en de meting tien jaar na afstuderen in 2005 aan elkaar gekoppeld. Tabel B.3 laat de responscijfers voor de gekoppelde bestanden zien.

\section{Tabel B.3}

Responscijfers gekoppelde bestanden

\begin{tabular}{lcccc} 
& \multicolumn{2}{c}{ Cohort 1993-1994 } & \multicolumn{2}{c}{ Cohort 1998-1999 } \\
& Aantal & Respons & Aantal & Respons \\
alumni & alumni & 14 & $\%$ \\
FdAW & n.v.t. & n.v.t. & 28 & 32 \\
FdCW & n.v.t. & n.v.t. & 311 & 20 \\
FdEWB & 192 & 21 & 251 & 20 \\
FdG & 172 & 24 & 306 & 32 \\
FdGW & 381 & 35 & 231 & 16 \\
FdR & 194 & 23 & 1.251 & 20 \\
Totaal & 1.048 & 25 & &
\end{tabular}

Bron: ROA 